UNIVERSIDADE DE SÃO PAULO

Faculdade de Economia, Administração e Contabilidade

Departamento de Contabilidade e Atuária

\title{
O ACORDO DA BASILÉIA \\ UM ESTUDO DA ADEQUAÇÃO DE CAPITAL NAS INSTITUIÇÕES FINANCEIRAS
}

\section{Raimundo Nonato Rodrigues}

Orientador: Prof. Dr. Eliseu Martins

Dissertação apresentada à Faculdade de Economia, Administração e Contabilidade da Universidade de São Paulo para a obtenção do Título de Mestre em Contabilidade. 
Reitor da UNIVERSIDADE DE SÃO PAULO

Prof. Dr. Jacques Marcovitch

Diretor da Faculdade de Economia, Administração e Contabilidade Prof. Dr. Denisard Cnéio de Oliveira Alves

Chefe do Departamento de Contabilidade e Atuária, em Exercício Prof. Dr. Eliseu Martins 
À minha esposa Luciene,

e aos meus filhos Laís, Marcéu e Jonas

dedico este trabalho. 


\section{A G R A D E C I M E N T OS}

A conclusão de um trabalho de dissertação não pode ser creditada somente ao seu autor. Todos presentes no seu ambiente formam, sem dúvida, uma sinergia que o fortalece e o impulsiona para a obtenção do seu objetivo. Desta forma, é plenamente justificável que o autor manifeste os seguintes agradecimentos:

- A Deus, pelas condições favoráveis que me possibilitaram a consecução deste objetivo;

- Ao Banco do Nordeste, por ter patrocinado a minha participação no mestrado, seguindo a filosofia de que a qualificação dos seus profissionais é um dos principais instrumentos para vencermos os constantes desafios que nos são impostos;

- Ao Professor Doutor Eliseu Martins, que acreditou no nosso potencial e nos incentivou para o alcance das nossas metas;

- Ao Professor Doutor L. Nelson Carvalho pelas críticas e sugestões apresentadas, fundamentais nos trabalhos desta espécie;

- À Universidade Potiguar - UnP, especialmente ao Prof. Jaime, pela manifestação de estímulo e apoio logístico imprescindíveis na fase de conclusão deste trabalho;

- Aos meus amigos e colegas pelo apoio indispensável, em especial Jeronymo, Paulo Schmidt, Lauro, Joanília e José Augusto. 


\section{R E S U M O}

O objetivo desta dissertação de mestrado é estudar a adequação de capital em bancos, com ênfase na implementação das regras do Acordo da Basiléia no sistema financeiro do Brasil.

Mesmo tratando-se de pesquisa de natureza acadêmica, na qual nos preocupamos em ressaltar os pontos de vista de diversos autores sobre os principais conceitos relacionados com o assunto, tais como, Capital, Risco, Insolvência e Desregulamentação, não nos furtamos em fornecer uma visão prática das medidas necessárias à implementação do Acordo da Basiléia nos bancos brasileiros, a partir da entrada em vigor da Resolução ${ }^{\circ}$ 2099, do Conselho Monetário Nacional.

Realizamos, também, um estudo crítico dos principais pontos constantes do Acordo da Basiléia, tecendo comentários a respeito dos aspectos que julgamos mais relevantes e relacionando-os com a realidade do mercado financeiro brasileiro.

Apresentamos evolução trimestral do índice de capitalização obtido de uma amostra de 10 bancos, no período de dezembro/94 a dezembro/96. Para cada um dos bancos foi feito um gráfico, que permite uma visualização adequada do grau de capitalização no período analisado.

Nosso estudo constata que as medidas de prudência aplicadas pelos organismos supervisores, notadamente no que se refere ao Acordo da Basiléia, se não forem aplicadas pelos bancos observando a essência dos seus ativos de risco, pouco contribuem para se mensurar o capital mínimo necessário para absorver eventuais perdas, nem possibilitam uma divulgação dos efeitos danosos dos créditos de alto risco nos demonstrativos financeiros, necessários para a tomada de decisões dos acionistas e demais usuários. 


\section{A B S T R A C T}

This dissertation studies the capital adequacy of banking, giving emphasis to the implementation of rules from the Basle Accord in the Brazilian Financial System.

Even though this is an academic research, in which we tried to underline many of authors' points of view about the most important concepts related to the subjetct, such as Capital, Risk, Insolvency and Deregulation, we did not avoid a practical view of the necessary acts to implement the Basle Accord in Brazilian banks, since Resolution $\mathrm{n}^{\mathrm{o}}$ 2099, from the National Monetary Council, was put in practice.

We also made a critical study about the main issues of the Basle Accord, making comments about the aspects we judged more relevant and relating them to the Brazilian financial market reality.

We present a three-month evolution of the capitalization ratio, taken from a sample of 10 banks, for the period from December/94 to December/96. To each bank a chart was prepared showing the degree of capitalization in the period analyzed.

Our study shows the prudent acts used by the supervision entities, specially refering to the Basle Accord. If these acts were not used by the banks observing the substance of their assets under of risk, they would not be very useful to measure their minimum capital needed to absorb eventual losses, and they would not be helpful to disclose the adverse effects from high risk credits in the financial statements such disclosure is necessary to help stockholders and other users to make their decisions. 
CAPÍTULO I: PROBLEMATIZAÇÃO 9

CAPÍTULO II: REVISÃO DA LITERATURA 13

2.1 Adequação de Capital na Indústria e nos Bancos 13

2.2 O Conceito de Capital 16

2.3 O Conceito de Risco 23

2.4 Tipos de Risco 27

2.5 Mensuração do Risco 32

2.6 Insolvência 35

2.7 Desregulamentação e Regulamentação Bancária 38

2.8 Sistemas de Informações Gerenciais dos Órgãos Supervisores 49

2.9 A Resolução no 2099 do Conselho Monetário Nacional e o Acordo da Basiléia

2.10 Os Limites Operacionais e a Resolução n 2099

CAPÍTULO III: METODOLOGIA DA PESQUISA

3.1 Tipologia do Estudo $\quad 60$

3.2 Caracterização das Variáveis $\quad 62$

3.3 População e Plano Amostral $\quad 64$

3.4 Coleta e Tratamento dos Dados $\quad 65$

CAPÍTULO IV: ANÁliSE DAS REGRAS DO ACORDO DA BASILÉIA 66

4.1 Os Componentes do Capital 66

4.2 Classes de Risco $\quad 74$

4.3 Risco de Transferência de País 77

4.4 Itens fora do Balanço $\quad 79$

4.5 O Risco de Crédito dos Derivativos 82

4.6 A Contabilidade e o Controle dos Riscos 89

4.6.1 O “Conservadorismo" nos Normativos (Prudência) 90

4.6.2 A Transparência nos Balanços (Evidenciação) 93

4.7 Índice Padrão $\quad 97$ 
4.8 A Incorporação do Risco de Mercado ao Acordo da

Basiléia

- Metodologias de Mensuração

4.9 Quadro-Resumo das Deficiências Apresentadas no Acordo da Basiléia

CAPÍTULO V: CONCLUSÕES E RECOMENDAÇÕES

APÊNDICE

115

BIBLIOGRAFIA

123

ANEXOS

129 


\section{CAPÍtULO I}

\section{PROBLEMATIZAÇÃO}

O processo histórico tem mostrado que a estabilidade econômica de um país está estreitamente ligada, dentre outros fatores, a um sólido sistema financeiro. Esta solidez é percebida quando os componentes do sistema, além de executarem as suas funções tradicionais de intermediação financeira, atendem às expectativas dos seus clientes, bem como mantêm um padrão de confiança aceitável no mercado.

Embora, do ponto de vista da Teoria Geral dos Sistemas (CHURCHMAN, 1972, p.35), a indústria bancária se enquadre perfeitamente como qualquer empresa que, no processo de interação com o ambiente, obtém recursos para transformá-los em produtos ou serviços, o que a particulariza das demais é a sua faculdade de usufruir principalmente dos recursos de terceiros para executar as suas funções básicas. Além disso, o impacto que pode causar sobre o meio circulante, sobre a inflação e no próprio sistema financeiro como um todo, reforça a necessidade de um controle mais rígido por parte dos órgãos supervisores sobre tais empresas, visando evitar uma sucessão de falências, a desconfiança dos depositantes e conseqüentemente a temida "corrida aos bancos".

A adequação de capital corresponde a um dos pontos de controle de que os organismos supervisores se utilizam para medir a solidez econômico-financeira dos bancos. A literatura tem mostrado que este tema gerou, e ainda gera, bastante polêmica entre os especialistas no assunto, dada a dificuldade de se encontrar o montante de capital necessário para absorver possíveis perdas nessas instituições financeiras. 
As diferenças surgem inicialmente devido às óticas distintas que possuem o órgão supervisor e o banqueiro. O primeiro tem por objetivo "maximizar" o capital próprio de forma a proteger os depositantes dos eventuais problemas de liquidez ou mesmo de insolvência que possam ocorrer; o segundo, prefere trabalhar com uma razão de capital próprio menor possível, obtendo o máximo de receita através do uso dos recursos de terceiros, mesmo se submetendo a custos de captação mais elevados.

As técnicas adotadas para se chegar a um capital adequado também divergem. MAISEL (1981, p.41) argumenta que a Teoria Moderna de Finanças tem tido grande progresso no conhecimento necessário para se medir o capital e o risco do portfólio, utilizando-se da metodologia denominada "marked to market", na qual, ao invés do valor histórico, é atribuído o valor de mercado ao ativo e ao passivo do banco. Para tanto, são utilizados os recursos da informática para a realização, em um curto espaço de tempo, de cálculos mais precisos nos mais variados instrumentos do mercado financeiro. Sob esse aspecto, aquele autor assim se expressa:

When their assumptions apply, these theories demonstrate that the task of measuring risk and capital adequacy can be accomplished with a limited number of formulas and a manageable amount of information.

Outros autores defendem que as diretrizes globais sobre adequação de capital podem se basear na razão capital/ativo. Referida razão, desde que superior ou igual a um determinado percentual, corresponderia a um padrão aceitável de capital que permitiria aos bancos realizarem as suas atividades, inclusive no âmbito internacional. Neste caso, o conceito de capital é redefinido abrangendo, além do capital registrado tradicionalmente como tal na contabilidade, outros elementos que possuam as mesmas características de 
capital (estejam disponíveis para absorver eventuais perdas). No tocante aos ativos, a eles são atribuídos pesos que variam entre 0 e 100\%, segundo determinadas classes predefinidas.

Além da proteção aos depositantes acima mencionada, outros fatores, segundo KAPSTEIN, também levaram os órgãos supervisores a estabelecerem regulamentos sobre padrões de capital (1994, pp.5-12). Dentre eles, destacamos:

a) crise nos bancos participantes do mercado internacional: Herstatt Bank (Alemanha), Franklin National Bank (E.U.A) e o British-Israel Bank (Inglaterra), em 1974, que culminou na formação do comitê sobre regulamentação e supervisão bancária - G-10, hoje conhecido como Comitê da Basiléia;

b) os elevados índices de inflação, a volatilidade nas taxas de juros e de câmbio;

c) o processo de globalização das finanças, no qual os bancos se engajam fortemente nas atividades internacionais, realizando operações tanto ativas como de captação de recursos. Na década de 80, o número de agências de bancos estrangeiros nos EUA elevou-se para 800, quando na década de 50 situava-se em torno de 100 unidades, o que proporcionou um aumento da participação das operações internacionais no lucro total dos bancos de 30\% para 60\% (The Economist, 1984);

d) criação de novos instrumentos financeiros (securitização, operações fora do balanço, derivativos etc) que tornam complexo o cálculo do capital necessário para cobrir os riscos a eles inerentes; 
e) a especulação nas taxas de câmbio nos anos 70: a grande volatilidade das taxas proporcionava grandes resultados - ora positivos, ora negativos;

f) a desregulamentação do sistema financeiro, durante os anos 70 e 80 , provocou novas oportunidades nos bancos comerciais, porém expondo-os a novos riscos;

g) dívida dos países do terceiro mundo: a decretação da moratória pelo México, no início dos anos 80, causou pânico entre os países industriais, temerários de que outros países latino-americanos adotassem o mesmo procedimento.

Determinar o capital adequado nos bancos tem sido um tema gerador de muita polêmica, em virtude dos diversos efeitos que pode causar na estrutura patrimonial de tais instituições. Desta forma, justifica-se a elaboração de estudos que analisem as possíveis conseqüências, destacando, quando possível, a experiência de outros países no assunto.

Esta dissertação tem o objetivo de adicionar aos estudos da adequação de capital em bancos uma pesquisa sobre a experiência brasileira, notadamente no que se refere à aplicação das regras do Acordo da Basiléia e da Resolução nº 2099, do Conselho Monetário Nacional. 


\section{CAPÍtulo II}

\section{REVISÃO DA LITERATURA}

Neste capítulo trataremos de alguns dos aspectos relacionados à teoria da mensuração do risco e da adequação do capital em bancos. Destacaremos, também, a definição conceitual e operacional dos principais termos relativos às áreas de economia, contabilidade e finanças que serão utilizados ao longo do trabalho. Preocupamo-nos em rever os principais livros, trabalhos e artigos que tratam deste assunto, dentre os quais encontramos as contribuições de Sherman J. MAISEL, Charles A. Stone e Anne Zissu, Itzhak Swary e Barry Topf, James G. Ehlen Jr. e outros.

\subsection{Adequação de Capital na Indústria e nos Bancos}

Quando observamos uma indústria manufatureira sob um enfoque sistêmico, verificamos que ela tem uma responsabilidade social de fornecer produtos que atendam da melhor forma possível às necessidades dos seus clientes. Para tanto, utiliza-se de recursos humanos, materiais, tecnológicos, financeiros etc. Dentre os recursos financeiros da indústria falaremos um pouco sobre o capital.

MAISEL, no livro intitulado "Risk and Capital Adequacy in Commercial Banks" ao se referir à adequação de capital na indústria, enfoca que, neste tipo de empresa, o capital adequado depende do tipo de indústria e dos possíveis riscos assumidos, quando afirma: 
In most industries, the amount of capital deemed adequate for a firm is found to vary widely depending upon the type of firm and the attitudes of its owners and creditors toward risk (1981, p.19).

Por outro lado, a adequação de capital dos bancos é vista de forma mais rigorosa. Pelo fato de serem empresas que lidam, em sua grande maioria, com recursos de terceiros, os aspectos de credibilidade, liquidez e solvência dos bancos são preocupações constantes que as autoridades monetárias devem ter. Sob esse enfoque, a visão do capital de um banco no aspecto macroeconômico é de suma importância para a estabilidade do sistema financeiro de um país. MAISEL, quando se refere a um capital adequado para um banco, assim se expressa:

The amount of capital needed hinges upon what risks of insolvency are considered suitable for the economy (1981, p.19).

Os riscos, a que se refere MAISEL, dependem da combinação dos ativos, dos passivos e do capital presentes no portfólio de um banco. Segundo esse autor, para se determinar o capital adequado é necessário se medir corretamente os riscos envolvidos, bem como o valor econômico do capital.

MAISEL ressalta, também, a diferença entre os bancos e as outras empresas, no que tange à natureza, à quantidade e à qualidade dos fornecedores de recursos, quando afirma:

The contrast between banks and other firms is inherent in the nature of their functions. Most firms deal with a limited number of suppliers of funds who tend to be sophisticated and, in addition, can impose restrictions on 
the firm's borrowing and operations to protect their funds. Banks, on the other hand, deal with numerou depositaras and creditors. Most custemos ave no coice expecta to hol. the bank's liabilities as long as they need deposit services...(1981, p.19).

EHLEN, referindo-se especificamente à missão do capital, além de ressaltar a sua importância, enfoca que não existe diferença do capital dos bancos para o de outras empresas; apenas que a sua adequação consiste em uma medida evasiva e que só o consenso do mercado pode validar essa adequação:

The role of capital in banking is no different from its mission in any business endeavor. It reflects a core or base of funds permanently employed in the business that affords a sense of financial stability to the organization and the wherewithal to deal with adversity. The degree of its presence generally is viewed as a measure of relative financial strength.

In both banking and industry, the adequacy of capital is an elusive measure. Perhaps the only real determinant of adequacy is the aggregate consensus of the marketplace (EHLEN, 1985, p.372).

Segundo REED e GILL, a adoção de um conjunto de padrões para testar a adequação de capital de um banco, embora seja utilizada pelas partes interessadas (supervisores e banqueiros), não deve ser considerada um fim em si próprio:

Um banco não tem capital adequado apenas porque se conforma com alguma média estatística. Será que está livre de críticas só porque satisfaz 
um índice qualquer?... A investigação deve ir além do quociente e fazer um exame das operações de um banco e dos riscos que ele assume em sua carteira de empréstimos e investimentos (1994, p.207).

O Comitê da Basiléia decidiu pela utilização de um índice para determinar a adequação do capital dos bancos, mesmo reconhecendo as limitações apresentadas por esta sistemática, quando, em seu relatório, afirma:

También debemos subrayar que la adecuación del capital, medida por el marco legal que se propone, aun cuando no deja se ser importante, sólo es uno de los numerosos factores que se deben tomar en cuenta para evaluar la fuerza de los bancos.

No presente trabalho, teceremos nossas análises com base na adequação de capital proposta pelo Comitê da Basiléia, porém não nos dispensando, no que couber, de eventuais críticas que, no desenvolvimento da pesquisa, se fizerem necessárias.

\subsection{O Conceito de Capital}

Além de ser entendido estritamente sob o ponto de vista conceitual, o termo capital também pode ser interpretado sob a ótica econômica, financeira e contábil. Segundo AURÉLIO:

O termo capital, do latim capitale, se adjetivado, quer dizer: principal, essencial, fundamental, primário; quando substantivo, significa: "riqueza ou valores disponiveis; qualquer bem econômico suscetivel de ser aplicado 
na produção"; qualquer riqueza capaz de dar renda e que se emprega para obter nova produção: "Não será esta uma questão capital: saber até que ponto depende o desenvolvimento da presença e influência do capital estrangeiro?(Barbosa Lima Sobrinho, Estudos Nacionalistas, p.3.)"; fundo de dinheiro ou patrimônio de uma empresa; cabedal (1986, p.343).

Verificamos na conceituação acima, que o autor destaca o aspecto econômico, quando se utiliza das expressões "riqueza ou valores", "bem econômico", "riqueza capaz de dar renda", deixando uma lacuna no que se refere à visão financeira e contábil do termo.

EHLEN, na sua definição de capital, faz a diferenciação entre a indústria tradicional e a indústria bancária, ressaltando os aspectos econômicos e contábeis, além da influência de algum tipo de regulamentação, quando afirma:

Generally, or at least in an industrial context, capital suggests simply the owner's equity in the organization. Over the past decade or so, capital within the banking industry has become, due to regulatory convention, a blending of common stockholders' equity, reserves and other permanent or semi-permanent sources of funds (1985, p.372). 
Na conceituação de MAISEL, verifica-se a sua preocupação em ressaltar o valor de mercado como melhor parâmetro para o capital, porém, desta vez, auxiliando-se de termos contábeis como ativo (inclusive intangível) e passivo, ambos, com fundamentação econômica, ou seja, desvinculados dos tradicionais valores registrados nos livros:

Capital refers to the market value of a bank's capital. It reflecs the fact that the market values of both assets and liabialities will differ from book values, and that numerous intangible assets and liabilities may not appear on the books. Capital may be thought of as the difference beween the asset side of the economic balance sheet, where all tangible and intangible assets are valued at market or economic values, and the economic value of deposits, borrowed funds, and implied as well as actual commitments (1981, pp.35-36).

GITMAN, em seu livro Princípios de Administração Financeira, ao se referir ao termo capital, o faz ressaltando o aspecto de sua estrutura dentro da empresa, distinguindo-o em dois tipos básicos: capital de terceiros e capital próprio. Segundo este autor:

Embora ambos representem fontes de fundos para a empresa, eles têm certas diferenças que os caracterizam. O termo capital denota fundos da empresa a longo prazo. Todos os itens à direita do Balanço Patrimonial, com exceção dos passivos circulantes, são fontes de capital (1984, p.513).

No campo da teoria da contabilidade, consultando a obra de HENDRIKSEN (1982, 487-497) constatamos que aquele autor não se atém especificamente ao item capital e sim ao conjunto do patrimônio líquido como um todo. Nela o autor trata das diversas teorias 
disponíveis sobre o assunto (proprietário, entidade, acionista ordinário, dos fundos, do comando e do empreendimento), ressaltando, todavia, que nenhuma delas pode ser utilizada em todo o tipo de empresa. A esse respeito, assim se expressa IUDÍCIBUS:

...várias teorias explicativas do patrimônio líquido (ou de sua natureza) são disponíveis, cada uma com seus méritos e limitações e nenhuma podendo fornecer base completa de explicação (1987, p.162).

Mesmo assim, HENDRIKSEN, ao discorrer sobre a teoria do proprietário, refere-se ao conceito de capital, sob um ponto de vista econômico (riqueza líquida), quando cita a opinião de HATFIELD:

HATFIELD, however, in his discussion of the proprietary concept, treated liabilities as negative assets and stated that capital, “... in the initial bookeeping equation, represents the net wealth of the proprietor" (1982, p.488).

Quando introduz a sua discussão sobre capital, FISHER apud CHAMBERS chama a atenção para a diferença entre estoque e fluxo de riqueza. Segundo este autor:

O capital se define como um estoque de riqueza existente em um determinado instante do tempo, enquanto que lucro, um fluxo de serviços durante um periodo de tempo (1971, p. 139). 
Ainda, no âmbito da contabilidade, MOST destaca as diferentes definições de capital, extraídas do Kohler's A Dictionary for Accountants (1977, p.126):

1. bens produzidos ou destinados a nova produção;

2. o valor investido na empresa pelos seus proprietários; capital integralizado;

3. capital subscrito;

4. valor investido mais lucros retidos; riqueza líquida; ativo líquido; patrimônio líquido;

5. patrimônio líquido mais exigível a longo prazo;

6. economia: bens de produção; riqueza empregada com o fim de obter lucro; qualquer riqueza utilizada com o intuito produtivo; riqueza líquida mais o exigível; ativo total.

ELLERT (1990, p.105), em seu livro Bank Financial Management, mesmo não apresentando uma definição clara de capital, destaca três propriedades importantes, necessárias para determinar a base de capital, com o objetivo de medir a sua adequação aos bancos canadenses:

1. sua permanência;

2. ausência de encargos fixos obrigatórios contra os ganhos; e

3. subordinação aos direitos dos depositantes e outros credores do banco. 
Uma vez que somente as ações ordinárias, os lucros retidos e as reservas gerais atendiam simultaneamente às três propriedades, os regulamentadores dos bancos dos Estados Unidos e do Reino Unido permitiram a inclusão de instrumentos de dívidas (ações preferenciais e debêntures subordinadas) na base de capital dos bancos, desde que sujeitos a algumas restrições. Tal precedente, também seguido pelos bancos canadenses, fez com que se dividisse a base de capital em dois componentes: capital básico e suplementar.

Quando trata da medição do capital para fins de regulamentação, ELLERT enfoca a diferença fundamental entre os dois componentes:

...o capital base compreende os componentes sobre os quais não há dúvidas a respeito da permanência e subordinação aos depositantes $e$ outros credores; e, na hipótese de uma grande queda nos lucros, em que os custos de serviços pudessem estar significativamente limitados ou ser eliminados, o banco não ficaria em situação de inadimplência. Já o capital suplementar normalmente compreende instrumentos financeiros residuais que não possuem todas as propriedades de capital exigidas (1990, p.106).

KEETON (1994, p.144), ao discorrer sobre os fatos que antecederam o Acordo da Basiléia, cita que:

...em 1985 o Federal Reserve (FED), o Federal Deposit Insurance Corporation (FDIC) e o Office of the Comptroller of the Currency (OCC) concordaram em impor a todos os bancos as mesmas exigências de capital, dividindo-o em duas medidas: a primeira, chamada capital primário, consistia do patrimônio líquido, das provisões sobre perdas em 
empréstimos, das ações preferenciais perpétuas e das dividas conversíveis; a segunda, denominada capital total, incluía além dos itens anteriores, as dividas subordinadas e as ações preferenciais de vida limitada.

Quando trata da definição de capital prevista no Acordo da Basiléia, o citado autor afirma que foi dada maior ênfase sobre o patrimônio líquido e menor sobre as provisões sobre perdas em empréstimos, além de se introduzir duas medidas de capital: restrita e ampla, ambas, na realidade, extensões do conceito de capital base e suplementar citado por ELLERT.

A medida restrita do capital é o que se convencionou chamar de "Tier 1, core ou categoria 1", consistindo fundamentalmente do patrimônio líquido tangível, ou seja, desconsiderando-se o goodwill ${ }^{1}$. A principal diferença entre o core capital e o capital primário é que ele exclui todas as provisões sobre perdas em empréstimos, devido ao fato de as mesmas estarem vinculadas a perdas previsíveis, tornando-as indisponíveis para absorver perdas inesperadas. Além disso, o core capital é também mais restritivo, uma vez que exclui as dívidas conversíveis e as ações preferenciais perpétuas.

Por outro lado, a medida ampla do capital, também chamada de capital total, é representada pela soma do capital principal (core) com o capital suplementar. Este último, também conhecido como "Tier 2" inclui dívidas subordinadas, provisões sobre perdas em empréstimos (com algumas restrições), reservas não publicadas etc.

\footnotetext{
${ }^{1}$ Segundo Monobi (1987), "Goodwill é uma resultante do valor da empresa como um todo, em termos de sua capacidade de geração de lucros futuros, e do valor econômico dos seus ativos identificados e contabilizados". Martins (1972), ressalta que na obtenção do Goodwill Global, uma dos fatores fundamentais são os recursos humanos, pois são os únicos capazes de atuar sobre os demais ativos e produzir resultados positivos, através de uma gestão eficaz e eficiente.
} 
Ainda na opinião de KEETON:

... a principal diferença entre o conceito anteriormente utilizado e o novo é que este último inclui uma quantidade limitada de provisões para perdas em empréstimos, enquanto que no primeiro todas as provisões são incluídas.

Analisando sob a ótica da garantia que os depósitos possuem nos EUA, amparados que são pelo FDIC, BENSTON (1994, p.349) ressalta que somente os recursos não cobertos pelo seguro deveriam ser protegidos por uma determinada quantia de capital. Assim se manifesta o autor:

For banks, capital should be defined as the sum of equity and debt that is not insured by the FDIC. Capital, so defined, serves two important purposes. One is to absorb losses incurred by a bank. ...

The second purpose of capital is to serve as an incentive to nongovernment agents to monitor a deposit-insured bank's risk taking and other activities.

\subsection{O Conceito de Risco}

No presente estudo, o termo "risco" será objeto de exaustivas referências, dada a sua relação direta com a adequação do capital dos bancos. Neste tópico, serão apresentadas as opiniões de diversos autores a respeito do conceito de risco, até chegarmos a um consenso da visão mais apropriada para ser utilizada ao longo deste trabalho. 
Dentre as várias conceituações de risco previstas na obra de AURÉLIO, aquela que ao nosso ver mais se aproxima do que pretendemos é a seguinte:

Risco significa perigo ou possibilidade de perigo.

No contexto dos bancos, por exemplo, o aumento da inadimplência por parte dos devedores constitui-se em um "perigo", que pode acarretar problemas de liquidez, solvência ou até desconfiança para os seus depositantes, caso o banco não disponha de recursos para atender aos saques.

Utilizando-se de uma linguagem voltada fundamentalmente para os fatores necessários a uma avaliação da taxa de juros, SOBRINHO afirma que risco é:

A probabilidade de o tomador do empréstimo não resgatar o dinheiro (1986, p.17).

Quando trata dos riscos do ativo, do passivo e total, CAPELO destaca a importância do conceito de risco para as abordagens probabilísticas e determinísticas da análise de investimento, devido às suas implicações na mensuração do custo do capital. No seu entender, risco, em sua essência, pode ser conceituado da seguinte forma:

A possibilidade, a chance, a probabilidade de ocorrência de um evento desagradável e indesejável, como um acidente ou uma perda. Em Finanças, entre outras coisas, o que se teme é o insucesso de um investimento que, em última análise, significa a não geração de resultados no montante mínimo 
requerido para deflagrar a decisão de nele investir, incluindo-se também a possibilidade de produzir prejuizos (1977, p.43).

GITMAN ressalta:

...os estatísticos diferenciam risco de incerteza ao afirmarem que o risco existe quando quem toma decisões pode estimar as probabilidades (distribuições probabilísticas objetivas, baseadas em dados históricos) relativas a vários resultados; enquanto que a incerteza, quando quem toma decisões não tem nenhum dado histórico e precisa fazer estimativas aceitáveis, a fim de formular uma distribuição probabilistica subjetiva (1984, p.131).

No estudo sobre análise de risco aplicada às decisões de investimento, MARTINS e ASSAF NETO abordam também o aspecto da incerteza na definição de risco. Para estes autores:

O risco refere-se basicamente à capacidade de mensurar o estado de incerteza através do conhecimento das probabilidades associadas à ocorrência de determinados resultados e valores (1986, p.456).

Voltando-se especificamente para a atividade bancária, CARVALHO (1993, pp.170171) define dois tipos de risco que, ao nosso ver, estão intimamente ligados à adequação de capital. Segundo este autor: 
Risco de Crédito: denominado, igualmente, "default” ou, ainda, qualidade de ativo, refere-se à probabilidade de receber fluxos de caixa de ativos quando prometidos.

Risco de "Leverage" - denominado, igualmente, capital, refere-se à minimização dos riscos de capital, visando proteger seus depositantes e investidores do declínio no valor de seus ativos.

Na visão de risco global de um banco, ROSENBERG e PERRY enfocam que devem ser levados em conta o valor de mercado das ações ordinárias e as mudanças na riqueza da empresa, quando afirmam:

The operating risk in a bank can be precisely defined as the unpredictable variability of the present value of the bank. Risk is most commonly studied by observing changes in the earnings or worth of the firm.

The market value of the bank's liabilities, at any point in time, is an estimate of the present value of the bank. The common stock is a large portion of the long-term capital of most banks, and it is that part with the greatest exposure to changes in the bank's present value (1981, p.371).

Vale ressaltar, também, o que afirmam os autores CATES e MORGAN a respeito da definição de risco, a qual defendem ser o denominador de uma importante taxa chamada de adequação de capital. Para eles: 
A única definição teórica que nós podemos aceitar é aquela baseada na variabilidade do fluxo de caixa líquido projetado a receber, relativamente às obrigações a serem cumpridas (1994, p.77).

Conforme demonstramos, o conceito de risco pode ser aplicado, tanto sob o aspecto global - do banco como um todo, como sob o aspecto específico - risco de crédito, de investimento etc. Porém, em ambos os casos, refere-se à probabilidade de ocorrência de eventos desfavoráveis, ou de insucesso no recebimento de eventuais retornos esperados. É sob esta ótica que serão abordadas as referências sob o risco no desenvolvimento deste trabalho.

\subsection{Tipos de Risco}

Nas instituições financeiras, e especificamente nos bancos, o risco se manifesta sob os mais diversos aspectos, dependendo do item ou dos itens que estejam sendo analisados. Neste segmento, detalharemos as mais diversas classificações de risco, ressaltando, no final, aquela a que os órgãos supervisores têm dado ênfase no seu controle.

GITMAN inicialmente apresenta uma classificação de risco conforme a quantidade de ativos que se esteja analisando. Para ele: "os conceitos básicos de risco podem ser vistos com relação a um ativo individual mantido isoladamente ou a uma carteira, ou coleção, de ativos”. Em seguida, ao tratar do modelo CAPM (modelo de precificação de ativos financeiros), aquele autor afirma que, sob este novo enfoque, existem dois componentes do risco de um título ou de uma carteira (1984, pp.131,139,144): 
- risco diversificável: representa a parcela do risco de um ativo que pode ser eliminada pela diversificação (greves, processos, ações regulatórias etc);

- risco não-diversificável: também chamado de sistemático, é atribuído às forças que afetam todas as empresas (guerra, inflação, incidentes internacionais e eventos políticos).

Embora apresente idêntica classificação à mencionada no parágrafo anterior, PAULA LEITE apud MARTINS e ASSAF NETO cita as principais fontes do risco diversificável, dividindo-as em três tipos:

- risco financeiro: refere-se à probabilidade de insolvência da empresa;

- risco de administração: relacionado à qualidade dos dirigentes da empresa;

- risco do setor: identificado nas crises do mercado.

Sobre o risco sistemático, PAULA LEITE afirma:

Tem origem nas flutuações a que está sujeito o sistema econômico como um todo, sendo as suas principais fontes as variações nas taxas de juros, o processo inflacionário e o comportamento das cotações do mercado de títulos (1986, p. 467).

CAPELO (1977, pp.48-49), ao tratar da inter-relação entre a remuneração requerida pelos acionistas e o risco, apresenta uma interessante abordagem, na qual decompõe o risco total da empresa em risco do ativo e risco do passivo. Conforme este autor: 
- risco do ativo: cuida de mensurar a variabilidade do lucro operacional produzido pelos ativos e diz respeito ao tipo de atividade que a empresa desempenha, à natureza dos bens e serviços que comercializa, às características mercadológicas e tecnológicas do setor onde se inclui e à administração que possui. É o risco básico de uma empresa em particular;

- risco do passivo: está vinculado à forma como a aquisição dos ativos foi financiada. É a visão do risco operacional feita como que através de lentes especiais, sendo que cada categoria de financiamento dispõe de sua lente específica, que é, cada vez mais, ampliadora de risco, quanto mais baixo se encontra o investidor na escala de preferências dos financiadores da empresa.

COMPTON, em seu livro Princípios da Atividade Bancária, aponta para a existência de dois tipos de risco (1990, p.226):

- risco de crédito: diz respeito ao fato de o tomador ser ou não capaz de amortizar conforme programado;

- risco de mercado: se o detentor de um investimento pretende vendê-lo a qualquer momento, as condições de mercado e a procura geral daquele título determinarão o valor de mercado, ou seja, o vendedor não pode controlar essas condições.

No entender de MAISON (1981, pp.33-34), para se avaliar um risco dever-se-ia dar ênfase ao exame das grandes classes de risco, ao invés de levar em conta apenas determinados empréstimos. Uma classificação adequada pode chamar a atenção para os pontos mais críticos, permitindo uma melhor otimização dos esforços. Desta forma, os tipos de riscos poderiam ser: 
- risco de oscilação das taxas de juros: se as taxas de juros aumentam, mudanças adversas significativas podem causar a insolvência dos bancos. O grau do perigo depende das datas estabelecidas para os fluxos de caixa dos ativos e passivos e da magnitude das alterações na estrutura das taxas de juros;

- risco de crédito: risco dos tomadores de empréstimo não quitarem as suas dívidas nas datas aprazadas;

- risco operacional: é o decorrente da deterioração da margem operacional. Esta depende do recebimento dos ativos, do custo dos fundos e dos gastos operacionais. O mau gerenciamento destes itens pode fazer com que o banco incorra em problemas de liquidez;

- risco de fraude: depende do tamanho do banco, tendo maior peso nos pequenos. À medida que um banco cresce, a probabilidade da fraude causar insolvência tende a decrescer;

- risco de fracasso na diversificação: tal fracasso pode decorrer tanto da concentração em operações de longo prazo, como na alocação de grande volume de recursos para um determinado cliente.

No modelo internacional para medição e padronização do capital apresentado pelo Comitê da Basiléia, encontramos referências a diversos tipos de riscos, porém com a ressalva de que, inicialmente, aquele comitê só levaria em conta no seu modelo o risco de crédito - dado que, segundo os seus autores, representava o risco de maior peso - e, como um de seus aspectos adicionais, o risco de transferência internacional. Este último consiste no risco de crédito oriundo de empréstimos concedidos a governos, instituições do setor público 
e bancos de outros países, podendo, ainda, ser subdividido, segundo REED e GILL (1983, p.539) em:

- risco de moeda: está ligado à conversibilidade e à estabilidade da unidade monetária do país do tomador;

- risco político ou do país: inclui determinadas incertezas que surgem de acontecimentos políticos e econômicos no país anfitrião e que influenciam a capacidade e disposição de os tomadores satisfazerem os compromissos assumidos;

- riscos regulamentários: são os riscos decorrentes das imposições ou alterações drásticas nas exigências de reservas, quociente capital/ativo, taxas especiais e uma variedade de outras regulamentações que obstruam as atividades bancárias.

O Suplemento de Janeiro de 1996, adendo ao Acordo da Basiléia de Julho de 1988, trata da exigência de capital sobre o risco de mercado ${ }^{2}$. Ao tratar deste tipo de risco, o Comitê assim o define:

Risco de perdas nas negociações e certas posições incluidas, ou não no balanço, oriundas de oscilações nos preços de mercado.

\footnotetext{
${ }^{2}$ Os riscos sujeitos a tais exigências são os seguintes: os riscos pertinentes a títulos de dívida e valores mobiliários contabilizados em carteira; o risco cambial e o risco com commodities que o banco incorre.
} 


\subsection{Mensuração do Risco}

O desenvolvimento de técnicas de aferição do risco presente nos negócios bancários tem sido constante ao longo da evolução desta atividade. A velocidade com que surgem novos produtos tem colocado os bancos diante de problemas complexos relativamente à medição dos riscos e aos sistemas de controle interno. Conseqüentemente, a mensuração do nível geral de risco dos bancos não tem sido fácil, exigindo para tanto o uso, por profissionais especializados, de recursos modernos de informática para a realização de cálculos matemáticos e estatísticos mais precisos.

Especificamente com relação ao risco de crédito, os bancos têm realizado provisões para fazer face às prováveis perdas com os créditos de liquidação duvidosa. No Brasil, o Conselho Monetário Nacional, através da Resolução $\mathrm{n}^{\circ}$ 1748, de 30.08.90, determinou os seguintes critérios para registro dos valores considerados como créditos duvidosos:

$\checkmark 20 \%$ sobre as operações amparadas por garantias que, a juízo das instituições, sejam consideradas suficientes à cobertura do saldo devedor atualizado, registradas em contas em atraso;

$\checkmark 50 \%$ sobre as operações amparadas por garantias que, a juízo das instituições ou a critério do Banco Central do Brasil, não sejam consideradas suficientes à cobertura do saldo devedor atualizado, registradas em contas em atraso;

$\checkmark 100 \%$ dos créditos inscritos em contas de créditos em liquidação.

As provisões calculadas conforme estabelecido pelo BACEN eram consideradas como despesas dedutíveis integralmente para efeito do imposto de renda até 1993. Após este 
ano, houve mudança de critério e a Receita só passou a aceitar como despesa dedutível os créditos que não foram pagos depois de todas as tentativas possíveis, ou seja, quando chegam à fase de cobrança judicial. Como deixou de existir a vantagem fiscal, os bancos não se sentem estimulados para o reconhecimento dos créditos como de liquidação duvidosa. Neste caso, deveria prevalecer a essência do fenômeno, ou seja, a perda real ocorrida no patrimônio do banco, independentemente da legislação tributária. Um procedimento correto seria divulgar um demonstrativo com base em dados reais (prevalecendo a essência ao invés da forma), para a tomada de decisões tanto dos acionistas quanto do órgão arrecadador de tributos.

Além da necessidade de realizar provisões sobre os riscos crédito na forma estipulada pela Resolução no 1748, o CMN estipulou regras relativas às exigências de Capital de acordo com os riscos de crédito dos ativos dos bancos, na forma prevista no Acordo da Basiléia, a qual trataremos com mais detalhe no item 4.1 do Capítulo IV.

O BACEN divulgou ${ }^{3}$ uma sistemática adicional de controle do risco de crédito presente no sistema financeiro nacional, a ser implementada a partir do segundo semestre de 1998. Segundo aquele Órgão, as instituições financeiras fornecerão mensalmente informações sobre as dívidas de clientes de valor superior a $\mathrm{R} \$ 50.000,00$, de forma a possibilitar uma estreita monitoração dos créditos, visando a estabilidade e solvência dos bancos.

Quanto ao risco de mercado, o Comitê da Basiléia elaborou, em janeiro de 1996, propostas - já devidamente aprovadas pelos países que compõem o Grupo dos Dez - que

\footnotetext{
${ }^{3}$ Gazeta Mercantil de 20 de agosto de 1997.
} 
estabelecem padrões de capital mínimo requeridos para as instituições financeiras, objetivando protegê-las contra tais riscos.

A partir de janeiro de 1998, os bancos serão obrigados a adotar uma das seguintes metodologias sugeridas por aquele Comitêt:

\section{Metodologia baseada no Modelo Interno de Gestão de Risco}

Esta metodologia possibilita aos bancos utilizarem os seus próprios modelos de avaliação de risco, desde que sejam observadas as seguintes condições:

a) certos critérios gerais a respeito da adequação do sistema de gestão de risco;

b) padrões qualitativos para fiscalização interna do uso dos modelos, com ênfase especial deste uso pela gerência;

c) orientações para se especificar um conjunto de fatores de risco de mercado apropriados;

d) padrões quantitativos que descrevem o uso de parâmetros estatísticos mínimos e comuns para se avaliar o risco;

e) processos de validação para auditoria externa do uso dos modelos;

f) regras para os bancos que utilizam uma combinação de modelos e do método padronizado.

\footnotetext{
${ }^{4}$ Referidas metodologias serão tratadas com maior detalhe no capítulo IV, item 4.7.
} 


\section{Metodologia Padronizada (Standard)}

NAKAMURA, quando se refere a este assunto assim se expressa: "Esse método usa a abordagem de "blocos de construção", em que os riscos específicos e riscos gerais de mercado são calculados separadamente e o risco total é obtido somando-se os riscos aritmeticamente" (1996, p.296).

Para os bancos que utilizam modelos internos com foco somente na exposição ao risco geral de mercado, o Comitê acredita que há necessidade de aporte de capital para cobrir os riscos específicos (proteção contra oscilações adversas no preço de um título, devido a fatores relacionados com o emitente) não capturados em seus modelos.

\subsection{Insolvência}

Neste tópico abordaremos os principais fatores que levam um banco à insolvência, baseados na contribuição de MAISEL que trata com bastante detalhe a respeito deste assunto.

MAISEL ressalta que a falta de planejamento é um fator preponderante para o declínio de um banco. Para ele:

A causa mais freqüente das perdas e da insolvência das instituições financeiras é o seu fracasso em planejar adequadamente os eventos possiveis de ocorrer. Desta forma, os bancos tornam-se insolventes quando, consciente ou inconscientemente, concentram grande parte dos seus empréstimos, investimentos ou atividades em áreas onde eventos 
imprevistos podem ser causadores de perdas substanciais. A possibilidade de altos lucros os induzem, também, a altos riscos no seu portfólio (1981, p. 2).

Para reduzir os riscos e conseqüentemente diminuir a possibilidade de insolvência, aquele autor cita quatro abordagens:

1. diversificar os componentes do ativo e do passivo a fim de que o impacto de eventos inesperados não seja irrecuperável;

2. medir o risco decorrente da não-diversificação ou da ocorrência de eventos inesperados através da distribuição de probabilidade dos resultados previstos. O conhecimento de tais riscos pode ser usado para os bancos reduzi-los a níveis considerados aceitáveis;

3. aumentar o capital, de modo que ele seja suficiente para absorver prováveis perdas;

4. reduzir o risco através da obtenção de seguro da FDIC.

Ao tratar da insolvência, MAISEL (1981, p.6) afirma que:

No início de qualquer período, um banco tem uma certa distribuição de ativos, passivos, compromissos e um volume de atividades a serem realizadas. Em termos econômicos, ele tem capital e reservas iguais à diferença entre o valor de mercado de seus ativos e de seus passivos. Com isso, espera obter um certo resultado durante o curso do ano, bem como efetuar os pagamentos dos seus passivos exigíveis. No começo do período, 
o seu resultado e a quantidade a ser paga aos seus fornecedores de recursos somente pode ser estimada. O seu valor esperado $e$ a probabilidade da ocorrência de eventos imprevistos causarão pequenas alterações desses valores dependendo da forma como o banco seleciona os seus ativos, suas operações e de movimentações na economia. No fim do periodo, os eventos imprevistos provavelmente causarão resultados bastante diferentes daqueles projetados.

O risco de o banco tornar-se insolvente depende do nível de resultado esperado e dos pagamentos a serem efetuados, da provável variância dos seus resultados e do seu capital inicial. O banco se tornará insolvente se os eventos formadores do seu resultado forem tão negativos que superem o seu capital mais as contribuições obtidas, deduzidas dos dividendos pagos durante o ano. A quantidade de risco depende tanto da probabilidade de insolvência provocada pelos movimentos negativos no resultado comparado com o capital inicial e reservas como da quantidade requerida pelos depositantes, emprestadores e investidores se a insolvência ocorrer.

Para o propósito de medir a adequação de capital, um banco pode ser considerado insolvente quando a sua liquidez é tão baixa que ele não pode pagar as suas dívidas; ou quando o valor de mercado de seus ativos, reduzidos pelos custos da falência, seja menor do que o valor de suas obrigações para com os seus clientes. 
Para MAISEL (1981, p.22):

A real determinação da insolvência não é um procedimento simples. Uma determinação acurada requer o cálculo do valor presente do banco baseado nos fluxos de caixa descontados. Deve existir também uma estimativa se em períodos futuros o banco estará hábil para suportar as demandas de caixa projetadas. Quando são descontados para determinado valor presente, os fluxos de caixa futuros devem ser ajustados pelos seus riscos e incertezas. Se os passivos do banco mais o custo da falência forem maiores que os ativos, ele estará insolvente.

\subsection{Desregulamentação e Regulamentação Bancária}

O simples fato de trabalhar em grande parte com recursos de terceiros - em alguns casos, a serem exigidos em qualquer momento - faz com que o banco seja um tipo de empresa que possui características bastante peculiares. Este fato, aliado a acontecimentos relacionados às sucessivas falências, má administração, localização incorreta de agências, problemas de liquidez etc, obriga os governos, através de seus órgãos supervisores, a impor normas conservadoras que possibilitem ao sistema bancário demonstrar confiança aos agentes poupadores da economia. Por outro lado, a indústria bancária ao se defrontar com uma gama de novos instrumentos financeiros, em um mercado cada vez mais competitivo e sem fronteiras, busca formas de regulamentação mais flexíveis para se adaptar a este novo ambiente. Tal fato gera uma busca por um ponto que otimize o interesse dos banqueiros com os dos órgãos regulamentadores. 
Neste tópico, serão mostrados os pontos de vista de diversos autores a respeito da desregulamentação e regulamentação bancária. No bojo dessas regras, encontraremos argumentos que tentam justificar a exigência de capital mínimo para acobertar eventuais perdas decorrentes de ativos sujeitos aos mais diversos tipos de risco. Como contribuição adicional, apresentamos no anexo 1 um quadro contendo o resumo da regulamentação vigente na Suíça, Alemanha, França, Reino Unido, Japão, Canadá e Estados Unidos, extraído da obra de SWARY e TOPF, através do qual depreende-se a preocupação dos órgãos regulamentadores em controlar os riscos oriundos das atividades bancárias, mesmo em prejuízo do processo decisório e das oportunidades de lucro.

A fim de percebermos a abrangência dos regulamentos na atividade bancária, citaremos, inicialmente, as afirmações de COMPTON (1990, p.306) ao se referir à regulamentação vigente nos Estados Unidos:

Muitos observadores de dentro e de fora do setor bancário o caracterizam como o setor com regulamentação e inspeção mais rígidas, freqüentes $e$ completas de todos os setores do país. Os sistemas de controle externos impostos pelos organismos do governo atuam mesmo antes de um banco iniciar suas operações; antes de poder aceitar seu primeiro depósito, um banco deve ser submetido a uma série de testes de qualificação, referentes à sua solicitação de carta patente.

Durante toda a sua vida, o banco está sujeito a uma série interminável de controles que o mantém alvo de inspeções detalhadas e restringem a gama de seus serviços. Mesmo após o banco ter fechado, oficialmente, os sistemas de controle externos se aplicam até que o último depositante 
tenha sido pago e que a última reivindicação tenha sido liqüidada. Talvez não haja empresas não bancárias sujeitas a tantas regulamentações $e$ restrições.

Embora o excesso de regulamentação seja motivo de severas críticas por parte dos banqueiros, a ausência total de regras também não é aceita nem pelos banqueiros nem pelos órgãos supervisores. Acerca da desregulamentação, COMPTON assim se expressa (1990, p.308):

\begin{abstract}
A desregulamentação não pode ser interpretada de forma a significar uma ausência total de controle federal ou estadual sobre a atividade bancária; ao invés disso, é uma expressão que indica o desejo de retirar algumas das restrições existentes enquanto se preserva os direitos dos governos de exercer um grau de regulamentação e supervisão do sistema bancário.
\end{abstract}

SWARY e TOPT (1992, p.3), quando discorrem sobre a tendência de desregulamentação existente nos principais mercados financeiros do mundo, citam exemplos que refletem os efeitos da competitividade e dos novos instrumentos financeiros no processo de desregulamentação da atividade bancária:

1. liberalização da taxa de juros, inclusive com remuneração dos depósitos;

2. redução das reservas compulsórias;

3. fim das restrições sobre expansão geográfica e das entidades não bancárias;

4. liberdade para os bancos participarem do mercado de capitais, inclusive os estrangeiros; 
5. possibilidade de utilização de novos instrumentos financeiros.

REED e GILL ao tratarem da desregulamentação bancária apresentam as seguintes considerações:

A opinião de que a regulamentação das empresas, em alta nesta última metade de século, deve ser revertida para fomentar um maior crescimento econômico, culminou, até certo ponto, na desregulamentação de vários setores da economia no início dos anos 80. Ressaltam, também, a lei DIDMCA (Depository Institutions and Monetary Control Act), de 1980, como uma das peças mais importantes da legislação financeira americana desde a década de 30, por criar impacto na competitividade dos bancos comerciais, na estrutura da indústria bancária e no desempenho de todas as instituições financeiras.

Para um melhor entendimento da sistemática vigente de regulamentação das instituições financeiras no Brasil, teceremos algumas considerações a respeito do Sistema Financeiro Nacional (SFN) e dos subsistemas que o compõem: normativo e de intermediação.

A estrutura do atual SFN é resultado de amplas reformas ocorridas nas décadas de 60 e 70, a partir da vigência da Lei da Reforma Bancária n 4595, de 31 de dezembro de 1964, da Lei de Mercado de Capitais no 4728, de 14 de julho de 1965 e da Lei ${ }^{\circ}$ 6385, de 7 de dezembro de 1976, que criou a Comissão de Valores Mobiliários. 
No subsistema normativo, encontramos o Conselho Monetário Nacional (CMN), no qual funcionam juntamente a Comissão Técnica da Moeda e do Crédito e as sete comissões consultivas (de Normas e Organização do Sistema Financeiro, de Mercado de Valores Mobiliários e de Futuros, de Crédito Rural, de Crédito Industrial, de Crédito Habitacional e para Saneamento e Infra-Estrutura Urbana, de Endividamento Público e de Política Monetária e Cambial), o Banco Central do Brasil (BACEN) e a Comissão de Valores Mobiliários (CVM). Estes órgãos regulam, controlam e fiscalizam as instituições financeiras, disciplinando as operações de crédito, a emissão e a distribuição de valores mobiliários. As normas são implementadas em função das decisões do $\mathrm{CMN}$, que emite resoluções, regulamentadas pelas circulares, instruções e atos declaratórios subseqüentes.

A seguir, são relacionadas as principais competências dos organismos formadores do subsistema normativo:

- CMN: na qualidade de principal órgão do sistema financeiro brasileiro, tem uma função exclusivamente normativa, responsabilizando-se pela fixação das diretrizes da política monetária, creditícia e cambial, harmonizando-as com as políticas de investimento, de capital estrangeiro, de comércio exterior, fiscal e salarial do Brasil;

- BACEN: é um órgão executivo, cabendo-lhe cumprir e fazer cumprir as disposições que lhe são atribuídas pelas legislação vigente e as normas emanadas do Conselho Monetário Nacional;

- CVM: voltada para o desenvolvimento, a disciplina e a fiscalização do mercado de valores mobiliários não emitidos pelo sistema financeiro (exceto as debêntures 
emitidas pelas sociedades de arrendamento mercantil - empresas que operam com leasing) e pelo Tesouro Nacional.

O subsistema de intermediação financeira é composto pelas seguintes instituições (bancárias, não bancárias e auxiliares), que operam em segmentos específicos do mercado monetário, de crédito, de capitais e cambial, todas porém subordinadas às normas legais expedidas pelos organismos do subsistema normativo: Banco do Brasil S.A., Banco Nacional de Desenvolvimento Econômico e Social-BNDES, Bancos Múltiplos, Bancos Comerciais Públicos e Privados, Bancos Estaduais de Desenvolvimento, Caixas Econômicas, Sociedades de Crédito Imobiliário, Sociedades de Poupança e Empréstimo, Sociedade de Crédito Financiamento e Investimento, Bancos de Investimento, Bolsas de Valores e Outras Instituições.

No atual sistema de regulamentação do Brasil, relativamente aos normativos emanados pelo CMN, verificamos a presença do Banco Central como organismo supervisor e orientador do sistema, através do qual se fazem cumprir as normas referentes ao capital mínimo, às provisões para fazer face aos créditos de difícil liquidação, à diversificação de risco por cliente, ao índice e alavancagem, de imobilização etc.

No cenário brasileiro, a desregulamentação mostrou-se presente com mais ênfase a partir de 31 de dezembro de 1994, com a entrada em vigor da Resolução no 2099 , do CMN, que tinha como principais objetivos, segundo o BACEN (1995, pp.12-14):

\section{Racionalização:}

- estabelecimento de condições idênticas para as instituições bancárias e não bancárias, oficiais e não oficiais; 
- eliminação do critério de atuação regionalizada e por praça aplicável às sociedades de crédito imobiliário, de crédito, financiamento e investimento, corretoras e distribuidoras de títulos e valores mobiliários;

- consolidação das normas, revogando-se mais de 50 normativos;

\section{Simplificação:}

- simplificação dos procedimentos relativos ao cálculo dos limites;

- redução do número de faixas de atuação das sociedades corretoras e distribuidoras de títulos e valores mobiliários;

- a maioria dos cálculos podem ser feitos com base em dados do COSIF;

\section{Modernização:}

- criação de transação via SISBACEN para cadastramento e troca de informações;

- adequação das normas vigentes ao modelo proposto pelo Acordo da Basiléia.

Quanto à regulamentação, COMPTON cita quatro fatores que, segundo ele, justificam o número e o tipo de restrições que são colocados sobre os bancos:

1. a atividade bancária tem um impacto imenso sobre a base monetária do país;

2. é essencial, para o bem-estar do país, que a confiança pública no sistema seja construída e preservada; 
3. nenhum setor afeta tanto o dia-a-dia dos outros como o setor bancário;

4. o alto grau de interdependência entre o bem-estar dos bancos e o da comunidade em que operam.

ELLERT, ao mencionar a forma como a regulamentação é vista em seu país, afirma:

\begin{abstract}
A regulamentação da atividade do mercado financeiro é vista como um meio de melhorar a eficiência econômica, um método de redistribuir os recursos financeiros de acordo com as prioridades nacionais e uma forma de promover a propriedade canadense no setor financeiro (1989, p.293).
\end{abstract}

A eficiência econômica estaria relacionada com a proteção do depositante, apoio à política monetária e manutenção de condições de concorrência nos mercados financeiros e não financeiros. A redistribuição incluiria o ensejo de assegurar a igualdade ou uniformidade no tratamento do mercado e proporcionar subsídios especiais a grupos específicos de participantes no mercado.

ELLERT cita diversos motivos que justificam a regulamentação bancária, ressaltando o que seria um princípio básico que nortearia os objetivos subjacentes. Ele parte do seguinte princípio:

Crença de que os mercados financeiros reais contêm imperfeições, sendo o objetivo da regulamentação atenuá-las, reduzindo o custo das transações de mercado, forçando os participantes do mercado a atuarem como tomadores de preço (para eliminar os lucros de monopólios) e melhorando o acesso às informações a respeito de preços e risco de mercado (1989, pp.293-294). 
Como objetivos específicos ELLERT destaca:

- manter a confiança pública no mecanismo de pagamentos (objetivo de política de longo prazo);

- promover a concorrência e limitar o exercício de poder de mercado;

- assegurar a solidez financeira do sistema bancário, através da limitação da estrutura de ativo e passivo, de esquemas de seguros de depósitos, de capital etc);

- influenciar a alocação do crédito, ou seja, promover a uniformidade de tratamento nos recursos financeiros e proporcionar subsídios especiais para categorias específicas de tomadores e credores.

Finalmente, aquele autor aponta alguns pré-requisitos que caracterizam um sistema ideal de regulamentação do mercado financeiro:

- redução dos custos das transações;

- melhoria do fluxo de informações a respeito de preços e riscos de mercado;

- manutenção de um cenário competitivo;

- reconhecimento dos custos diretos e indiretos de aplicar e acompanhar as limitações legais;

- manutenção da regulamentação somente quando os benefícios esperados excedessem os custos esperados; 
- funcionamento do sistema de regulamentação através de incentivos para atingir os resultados almejados;

- reconhecimento das diferenças nas categorias de risco;

- regulamentação semelhante para instituições financeiras envolvidas em atividades semelhantes;

- adaptabilidade, objetivando reconhecer a evolução de novas formas de instrumentos financeiros, novas tecnologias no fornecimento de serviços financeiros e alterações na estrutura de concorrência do mercado.

Na opinião de MAISEL (1981, p.137), o sistema de regulamentação existente objetiva controlar o capital, a liquidez, a diversificação e os riscos, ao mesmo tempo em que promove um gerenciamento sólido dos bancos. No entanto, o autor apresenta algumas críticas relacionadas às bases de controle e às avaliações subjetivas, quando afirma:

However, controls are based on tradition, industry norms, and subjective evaluations. How to measure risks and what constitutes adequate capital have not been formulated in objective terms.

Apesar de citar quatro razões para a regulamentação nos bancos (níveis de risco, informação, instabilidade e benefício público), MAISEL ressalta que o mais importante é a forma como são feitas as regulamentações.

Com respeito aos fundos de seguros de depósitos, MAISEL tece críticas afirmando que muitas seguradoras ajustam os seus prêmios de seguro com base nos riscos assumidos 
pelos segurados, o que não acontece com o FDIC, que determina os seus prêmios baseado nos depósitos e não sobre as potenciais perdas.

Devido à sua ênfase sobre o aspecto do risco, MAISEL destaca que a principal forma de controlar o risco em um banco tem sido através do que ele denomina de "process of bank examination”. Como pontos positivos deste processo, são citados os seguintes argumentos (1981, p.144):

The examination aims at judging the bank's compliance with existing rules and regulations. Equally, or more important, the examiners attempt to judge the soundness of the bank, its prospects of avoiding insolvency, and its ability to meet current and future needs of its community. The soundness of the bank is a function of its management, ownership, and operating procedures; its liquidity or ability to meet future demands for cash; and, above all, its capital adequacy.

Contudo, o citado autor, também, apresenta as seguintes críticas a respeito da eficácia do referido processo:

- medição de tendências com base em ações passadas. As situações atuais sobre o banco são analisadas e sugestões são feitas para aperfeiçoamentos. Os examinadores não têm atentado em medir os riscos do portfólio que crescem devido à sua exposição a eventos futuros. Pouca atenção é dada às possíveis oscilações nas taxas de juros; 
- relevância nas análises detalhadas de empréstimos individuais. O destaque é sobre a validade dos registros e sobre os atrasos no pagamento dos empréstimos;

- coloca muita ênfase na verificação do status do banco, ao tempo em que fornece algum peso a respeito das perspectivas de perdas e ganhos nos empréstimos. Se um banco tem um capital inadequado, a solução tem sido sugerir aos seus administradores o aumento do capital ou o decréscimo do risco.

\subsection{Sistemas de Informações Gerenciais dos Órgãos Supervisores}

As agências federais americanas de regulamentação e supervisão - $F E D, O C C$ e FDIC - adotam, segundo MAISEL, um sistema que viabiliza a avaliação dos bancos, com base em cinco fatores operacionais críticos, que, levando em conta o peso de cada um, no agregado, evidencia uma taxa representativa do desempenho do banco, variando numa escala de 1 a 5. As dimensões examinadas são: a adequação do capital do banco; a qualidade dos ativos (empréstimos e investimentos); a habilidade no gerenciamento do banco; a quantidade e a qualidade dos ganhos e o nível de liquidez.

O BACEN dispõe, semelhantemente, inserido na estrutura do seu sistema de informações, um instrumento que dá suporte à sua área de fiscalização, denominado de sistema INDCON - Indicadores Econômico-Financeiros de Instituições sob Acompanhamento e Controle do Banco Central do Brasil.

O objetivo do INDCON é “fornecer ao seu usuário recursos para análise do desempenho das instituições financeiras e acompanhamento do direcionamento das operações realizadas pelos segmentos do sistema financeiro" (BACEN, 1994, p. 9). 
Os dados integrantes do sistema INDCON são oriundos basicamente dos balancetes mensais, da estatística econômico-financeira fornecida pelos bancos, pela posição da conta Reserva Bancária e pela composição societária/natureza das instituições.

O processo de avaliação que o INDCON se utiliza, apóia-se em 68 indicadores econômico-financeiros, classificados em 5 grupos (cujas iniciais formam a sigla "CAREL"), conforme abaixo especificado (1994, pp. 12-19):

\section{C-Capital:}

- Estrutura das origens de recursos: são indicadores que procuram identificar a estrutura de captações das instituições, medindo a participação do capital próprio nos recursos totais e em relação aos capitais de terceiros, a captação no mercado interno, os recursos captados em moeda estrangeira etc;

- Comprometimento patrimonial: são indicadores que medem o comprometimento do capital próprio com imobilizações, operações ativas com características de anormalidade ainda não usuais, fora dos objetivos sociais da instituição. Medem ainda sua alavancagem, ou seja, quantas vezes assumiu obrigações e riscos em relação à sua base patrimonial (similarmente ao Acordo da Basiléia);

\section{A - Ativos:}

- Estrutura das Aplicações: são indicadores que procuram identificar o direcionamento dos recursos captados a nível de aplicações em ativos de liquidez imediata, carteira ativa, operações não usuais e direcionamento dos créditos ao setor público, atividades privadas e pessoas físicas, habitação etc; 
- Comprometimento das Aplicações: são indicadores que medem, em relação às aplicações, o nível de inadimplência e o de provisionamento de ativos financeiros e operações de crédito;

- Política Operacional: são indicadores que, através da relação entre itens de captação e aplicação, procuram verificar o equilíbrio da política operacional, comparando as captações totais com as aplicações em operações usuais, a parcela das operações usuais financiada por recursos sem remuneração e a aplicação em operações ativas de recursos competitivos captados no mercado;

\section{R - Rentabilidade:}

- Rentabilidade dos Recursos Próprios: são indicadores que medem a rentabilidade ou o retorno sobre o patrimônio líquido, mês a mês e ao longo do semestre, além de segregarem itens de receita ou despesa não monetária, cujo registro não implica alterações no fluxo de caixa;

- Rentabilidade Operacional: são indicadores que comparam o lucro líquido com o total das receitas, avaliam a participação do resultado não operacional, da carteira de câmbio e das rendas de prestação de serviços, além de calcular a taxa de retorno dos ativos;

- Remuneração das aplicações: são indicadores que apuram a margem operacional (spread) praticada pela instituição mediante a relação entre a taxa média de aplicação versus a taxa média de captação;

- Encargos e Custos: são indicadores que informam sobre o comportamento dos encargos das captações: recursos a prazo, em moeda estrangeira e captação total. 
Inferem a influência dos custos fixos (administrativos, com ênfase às despesas de pessoal) relacionando-os com as receitas operacionais e com o ativo envolvido;

\section{E - Eficiência Gerencial:}

- Desempenho das Dependências: são indicadores que medem os níveis de captação, aplicação e custos administrativos por agência ou dependência mantida. Acompanham o esforço para recuperação de créditos levados a prejuízo;

- Indicadores de Evolução: são indicadores que medem a evolução real do patrimônio líquido e das operações ativas usuais. Avaliam a participação da empresa no mercado mediante a variação de sua participação nas captações e aplicações em operações ativas usuais;

\section{L - Liquidez:}

- Liquidez: são indicadores que medem a situação financeira da instituição por meio dos índices tradicionais de liquidez, com destaque à obtenção de assistência financeira junto ao BACEN.

\subsection{A Resolução no 2099 do Conselho Monetário Nacional e o Acordo da Basiléia}

O Banco Central do Brasil divulgou, em 17.08.94, a Resolução nº 2099, do CMN, na qual foram implementadas, dentre outras medidas, as exigências de capital mínimo previstas no relatório International Convergence of Capital Measurement and Capital Standards, mais conhecido como Acordo da Basiléia, de julho de 1988. Deste primeiro relatório podemos destacar os seguinte pontos ${ }^{5}$ :

\footnotetext{
${ }^{5}$ Um estudo mais detalhado sobre o Acordo da Basiléia encontra-se no Capítulo IV.
} 
- Objetivo: atingir uma convergência na regulamentação e estabelecer padrões de adequação de capital que limitassem o risco do sistema financeiro internacional;

- Componentes do Acordo: representantes dos bancos centrais e autoridades supervisoras dos países do Grupo dos Dez (Alemanha, Bélgica, Canadá, Estados Unidos, França, Itália, Japão, Países Baixos, Reino Unido, Suécia e Suíça), além de Luxemburgo;

- Metodologia Adotada: foi adotada a técnica denominada "capital ajustado ao risco", na qual o capital mínimo dos bancos depende da estrutura dos seus ativos e dos riscos a eles inerentes;

- O Capital dos Bancos: é definido o que pode ser considerado como capital dos Bancos. Para tanto, são destacados dois tipos de capital ${ }^{6}$ : “Tier 1"(capital básico, formado pelo patrimônio líquido, acrescido das participações minoritárias e deduzido do ágio) e “Tier 2" (capital suplementar, formado pelas provisões adicionais para devedores duvidosos, acrescida de reservas ocultas, empréstimos subordinados etc.);

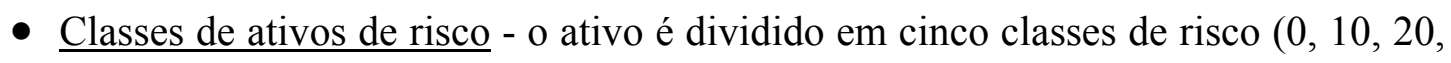
50 e 100 por cento), cuja exigência de capital estaria vinculada diretamente à classe de risco à qual o ativo estivesse enquadrado;

- Índice de Capitalização: o capital deveria representar, no mínimo, 8\% dos ativos ponderados pelo risco, de tal forma que o risco deixou de ser medido no passivo para ser medido no ativo, onde efetivamente ocorre;

\footnotetext{
${ }^{6}$ CARVALHO, Sílvio Aparecido de. Desenvolvimento de Novas Técnicas para a Gestão Bancária no Brasil.
} 
- Itens Fora do Balanço: em virtude do crescimento destes itens (cartas de crédito, compromissos de empréstimos, promessas de garantias etc) o Comitê exigiu um respaldo correspondente de capital, observando determinados fatores de conversão de crédito. Para as operações com derivativos (instrumentos financeiros que derivam ou dependem do valor de outro ativo) foi prevista uma metodologia específica.

No Brasil, o Conselho Monetário Nacional adotou em agosto de 1994 o índice de capitalização de 8\%, a ser observado a partir de 31.12.94, ocorrendo, porém, alguns ajustes devido às particularidades do sistema financeiro nacional - quanto à classificação dos ativos e à atribuição dos respectivos pesos (vide item 3.2 do capítulo seguinte). Desta forma, o cálculo do valor do Patrimônio Líquido Exigido pelo BACEN observou a seguinte fórmula:

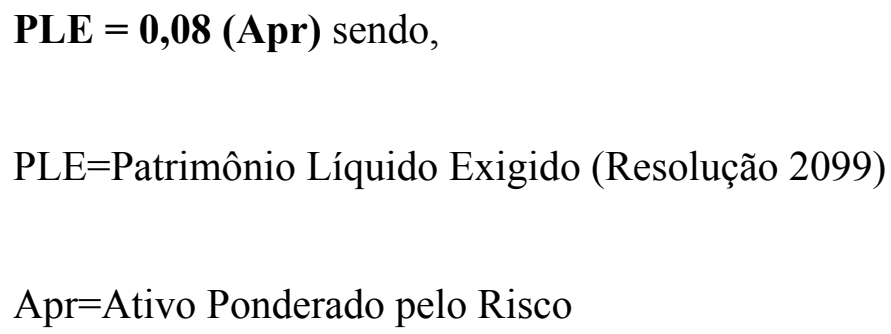

Tal fórmula foi alterada pela Resolução ${ }^{0}$ 2139, de 29.12.94, devido à inclusão das operações de "swap", em virtude do crescente número deste tipo de operação nos bancos e da necessidade de se aportar capital compatível com os seus riscos. Referida modificação entrou em vigor a partir de $1^{\circ}$ de julho de 1995 , exigindo um patrimônio líquido de acordo com a seguinte fórmula:

PLE = 0,015 (Sw) + 0,08 (Apr) sendo, 
Apr=Ativo Ponderado pelo Risco

$\mathrm{Sw}=$ valor total "notional" das operações de "swap" registradas em conta de compensação.

Em junho de 1997, a Resolução no 2399 do CMN elevou a exigência de capitalização dos bancos $8 \%$ para $10 \%$ dos ativos ponderados pelo risco, bem como alterou a forma de cálculo do capital necessário para cobrir o risco de crédito das operações de "swap":

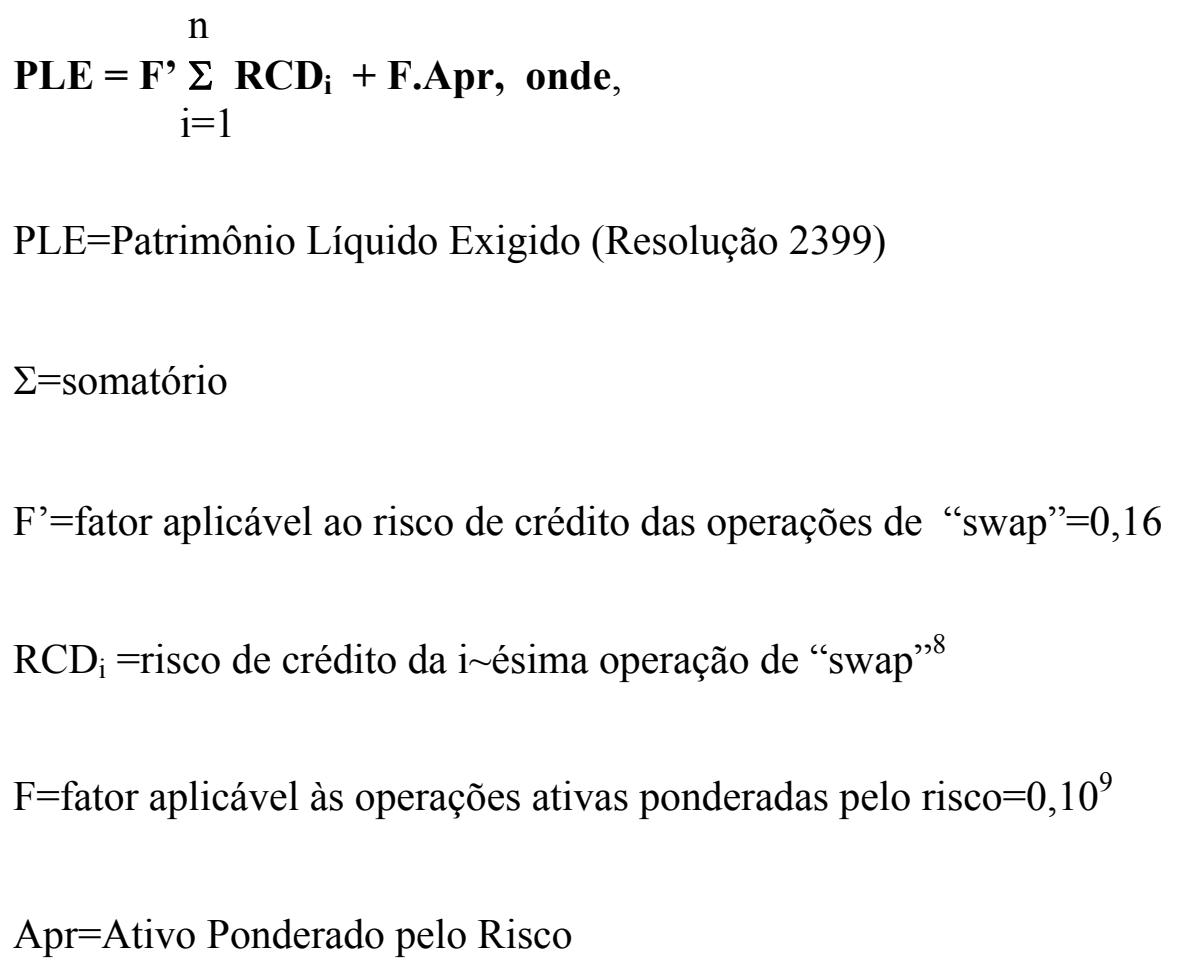

Em 27 de novembro de 1997, o Banco Central do Brasil, com o objetivo de reforçar a solidez do sistema financeiro nacional, através da Circular $\mathrm{n}^{\circ} 2784$, aumentou o fator de risco F para 0,11 e o F’ para 0,20 e, consequentemente, a exigência de patrimônio líquido dos bancos para as operações de crédito e de "swap".

\footnotetext{
${ }^{7}$ Valor do contrato de "Swap" no qual são gerados percentuais de responsabilidade efetiva.

${ }^{8}$ A fórmula do RDC encontra-se no capítulo IV, item 4.5, que trata do risco de crédito dos derivativos.

${ }^{9}$ Fator utilizado para as instituições autorizadas a funcionar pelo BACEN antes de 17/11/95.
} 
O Conselho Monetário Nacional, atento à evolução dos negócios envolvendo operações com "swap", determinou, através da Resolução $\mathrm{n}^{\circ} 2.138$, que as instituições financeiras atestassem, junto ao Banco Central do Brasil, a utilização de modelo de gerenciamento de risco compatível com a estrutura das referidas operações. Para tanto, as instituições financeiras encaminham àquele Órgão declaração - firmada pelo administrador tecnicamente qualificado, pertencente à sua diretoria - de que o modelo adotado propicia condições para o tempestivo acompanhamento dos riscos envolvidos em tais operações.

NAKAMURA (1996, p.295), ao discorrer sobre as medidas tomadas pelo CMN assim se expressa:

As novas disposições do CMN, isto é, capital adicional para operações de "swap" e controles para operações de derivativos estão em consonância com discussões ainda em andamento no Comitê da Basiléia, que pretende introduzir padrões de avaliação de risco de mercado e exigência de capital adicional para tanto (um “Tier 3”).

Conforme o Boletim do Federal Reserve, de março de 1996, o Comitê da Basiléia publicou, em 19 de janeiro daquele ano, um Suplemento Anexo ao Acordo da Basiléia, no qual trata especificamente da avaliação do risco de mercado, sendo composto por três documentos:

- Overview of the Amendment to the Capital Accord to Incorporate Market Risks;

- Amendment to the Capital Accord to Incorporate Market Risks; 
- Supervisory Framework for the Use of "Back-testing” in Conjuntction with the Internal Models Approach to Market Risk Capital Requeriments.

No que se refere ao conceito de capital, o Conselho Monetário Nacional não adotou o previsto no Acordo da Basiléia (capital principal e suplementar), mantendo como base de cálculo para o índice de capitalização o Patrimônio Líquido, ajustado às suas contas de resultado (PLA).

Embora não seja objeto do presente estudo, outro aspecto importante a se destacar na Resolução no 2099 foi a exigência de limites mínimos de capital realizado e patrimônio líquido para as instituições financeiras autorizadas a funcionar pelo BACEN. Ao requerer níveis mínimos mais elevados que os exigidos nos regulamentos anteriores, o CMN agiu prudentemente, com o objetivo de preservar a solidez do sistema financeiro, muito embora, tenha sido objeto de críticas de uma parcela de especialistas do mercado, que considera tal decisão uma forma de fixar barreiras à concorrência, ou seja, dificultar a competitividade no setor bancário, contribuindo conseqüentemente para sua oligopolização.

\subsection{Os Limites Operacionais e a Resolução nº 2099}

Alguns autores alegaram a superposição de regulamentos quando da entrada em vigor da Resolução $\mathrm{n}^{\circ}$ 2099, relativamente aos limites operacionais anteriormente previstos no Manual de Normas Internas do Banco Central do Brasil, tendo como conseqüência um aumento da regulamentação sobre os bancos brasileiros.

Para que se possa fazer um paralelo entre as duas situações, relacionamos os limites operacionais anteriores à Resolução $n^{\circ} 2099$ : 
a) Limite de Endividamento: 15 vezes o PLA (Patrimônio Líquido Ajustado);

b) Índice de Imobilização: O total de recursos aplicados no Ativo Permanente não pode ultrapassar a $90 \%$ do PLA;

c) Limite de diversificação de risco por cliente; Limite a ser observado nas operações de subscrição para revenda e de garantia de subscrição de valores mobiliários de emissão de uma única empresa; e, Limite de aplicação em títulos e valores mobiliários de um mesmo emitente: $30 \%$ do PLA;

d) Limite sobre operações compromissadas (operações com títulos públicos federais): até 10 vezes o PLA.

Dos limites acima citados, a Resolução n 2099 modificou o grau de endividamento dos bancos, reduzindo-o de 15 para 12,5 vezes $^{10}$ o valor do PLA, na medida em que exigiu uma capitalização mínima em $8 \%$ dos ativos ponderados por categorias de risco.

Na sistemática anterior, o risco era observado em função do endividamento do banco, não levando em conta as eventuais perdas nos ativos correspondentes. Para evitar os riscos inerentes à excessiva concentração de recursos em determinados clientes ou grupos econômicos, aplicar-se-iam os limites de diversificação de risco acima citados.

CAMPELLO expressa o seu ponto de vista da seguinte forma:

${ }^{10}$ Com a elevação do índice para $10 \%$ o endividamento foi reduzido para 10 vezes o PLA. Para as cooperativas de crédito, o endividamento ainda permanece em 15 vezes o PLA. Com a vigência da Circular $\mathrm{n}^{\mathrm{o}} 2784$, elevando o percentual para $11 \%$, o endividamento foi reduzido para 9,1 vezes o PLA. 
A adoção das normas da Basiléia não exime os bancos brasileiros da observância simultânea de limites operacionais ainda vigentes, implicando superposição de regulação (1995,p.34).

Analisando o conteúdo da Resolução n ${ }^{\circ}$ 2099, em sua edição especial, a ANDIMA ${ }^{11}$ Associação Nacional das Instituições do Mercado Aberto destaca o seguinte aspecto:

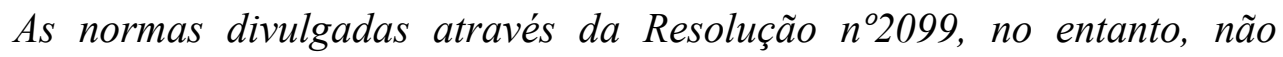
revogaram os limites operacionais hoje vigentes.

Assim, as instituições financeiras devem se preparar não só para cumprir as regras da Basiléia adaptadas para o Sistema Financeiro brasileiro nos prazos estipulados pelo Banco Central, como também para observar os limites ora vigentes para operações ativas, quanto a diversificação de risco, grau de imobilização e valores mobiliários...

A aplicação da Resolução $n^{\circ}$ 2099, a partir de dezembro de 1994, concomitantemente às exigências previstas nos limites constantes nas alíneas "c" e "d" acima, provocou a seguinte situação, caracterizada pela ANDIMA como um excesso de controle sobre as instituições financeiras: uma instituição que teoricamente só possuísse títulos federais, pelas novas regras teria alavancagem infinita, em virtude de apresentar risco zero. Por outro lado, limita-se à alavancagem de 10 vezes o PLA (alínea "d”) e aos parâmetros estipulados nas normas de diversificação de risco por cliente (alínea “c”).

\footnotetext{
${ }^{11}$ ANDIMA. Novas Regras redefinem o Sistema Financeiro.
} 


\section{CAPÍTULO III}

\section{METODOLOGIA DA PESQUISA}

$\mathrm{Na}$ elaboração de pesquisa de natureza acadêmica, no que se refere ao aspecto metodológico, faz-se necessário tecermos alguns comentários a respeito dos principais parâmetros que foram utilizados. Neste capítulo apresentaremos algumas considerações sobre o tipo de estudo adotado, das variáveis analisadas, da população, do plano amostral e da forma como os dados foram coletados.

\subsection{Tipologia do Estudo}

Ao tratar da tipologia de estudo que pode ser adotada nos trabalhos científicos, MARTINS (1992, p.27) apresenta um levantamento dos tipos mais utilizados nas pesquisas não experimentais - indicados para serem aplicados às áreas de Administração, Economia e Contabilidade - dentre os quais destacamos:

a) empírico-analíticas: abordagens que apresentam em comum a utilização de técnicas de coleta, tratamento e análise de dados marcadamente quantitativas. Privilegiam estudos práticos;

b) fenomenológico-hermenêuticas: abordagens que utilizam técnicas não quantitativas. Privilegiam estudos teóricos e análise de documentos e textos;

c) bibliográfica: trata-se de estudo para conhecer as contribuições científicas sobre determinado assunto. Tem como objetivo recolher, selecionar, analisar e interpretar as contribuições teóricas já existentes sobre determinado assunto; 
d) pesquisa descritiva: é aquela em que o pesquisador observa, registra, analisa e correlaciona fatos ou fenômenos (variáveis);

e) pesquisa exploratória: é uma abordagem indicada para a busca de maiores informações sobre determinado assunto de estudo;

f) pesquisa-ação: o investigador desempenha papel ativo no equacionamento dos problemas encontrados; etc.

A classificação acima não prevê fronteiras rígidas entre um tipo de pesquisa ou outra, podendo existir, conforme o objeto da pesquisa, combinações de duas ou mais modalidades. Desta forma, o presente trabalho posicionou-se entre as pesquisas do tipo empírico-analítica e fenomenológico-hermenêutica. O enquadramento dentro da primeira abordagem decorre do fato de termos efetuado uma coleta dos dados referentes à composição dos ativos e do capital dos principais bancos brasileiros, no período de dezembro/94 a dezembro/96, ou seja, após a obrigatoriedade da adoção do padrão de capital conforme a Resolução 2099, do CMN. A evolução de tais dados nos permitiu demonstrar o comportamento do índice de capitalização dos bancos. Situamo-nos também na segunda abordagem, uma vez que foram feitas diversas leituras e realizados vários posicionamentos no que se refere aos estudos teóricos já existentes sobre o tema - notadamente na literatura estrangeira, dada a escassez de estudos sobre este assunto no Brasil - além de documentos oficiais, críticas e análises de especialistas no assunto.

Além dos aspectos teóricos acima citados, convém ressaltar que a experiência do autor na atividade bancária, aliada à participação em seminários, entrevistas com técnicos de instituições financeiras, bem como, visitas às entidades de classe (Associação Brasileira de Instituições Financeiras de Desenvolvimento-ABDE, Associação Brasileira dos Bancos 
Comerciais Estaduais-ASBACE, Federação Brasileira dos Bancos-FEBRABAN etc), em muito contribuíram para enriquecer o presente trabalho de pesquisa.

\subsection{Caracterização das Variáveis}

MARTINS (1992, p.24) classifica as variáveis, no que se refere à sua especificidade, em variáveis gerais: que não podem ser imediatamente mensuradas; e variáveis empíricas: indicam diretamente os elementos e/ou características a serem observadas e medidas.

A fórmula que estabelece o índice de capitalização dos bancos (K=PLA/Apr) nos fornece as variáveis empíricas a serem analisadas no presente estudo. O PLA corresponde ao patrimônio líquido ajustado, de acordo com a seguinte fórmula, constante no plano contábil padronizado pelo Banco Central para as Instituições do Sistema Financeiro (COSIF): (+) patrimônio líquido Cód. $\mathrm{n}^{\mathrm{o}}$ 6.0.0.00.00-2, $(+)$ contas de resultado credoras Cód. $\mathrm{n}^{\circ}$ 7.0.0.00.00-9, (-) contas de resultado devedoras Cód. $\mathrm{n}^{\circ}$ 8.0.0.00.00-6.

No Ativo Ponderado pelo Risco (Apr), dada a impossibilidade de acesso aos níveis de subtítulos contábeis, o procedimento adotado foi o de se selecionar as seguintes categorias de ativos, que, após comparados os resultados obtidos, via simulação, em um período de nove trimestres, com os valores derivados da utilização de dados reais, encontramos diferenças irrelevantes no fator K (índice de capitalização), evidenciando um resultado muito próximo do que dispõe a Resolução nº 2099:

- Risco Nulo (Peso 0\%): Caixa, Reservas Livres em Espécie depositadas no BACEN, Aplicações em Operações Compromissadas, Depósitos Voluntários no Banco Central de Sociedades de Crédito Imobiliário, Aplicações em Títulos de 
Renda Fixa, Títulos Públicos Federais Depositados no BACEN e Valores Depositados no BACEN;

- Risco Reduzido (Peso 20\%): Depósitos Bancários de Livre Movimentação mantidos em Bancos, Aplicações Temporárias em Ouro Físico, Disponibilidades em Moedas Estrangeiras, Cheques e Outros Papéis Encaminhados ao Serviço de Compensação e Créditos Tributários;

- Risco Reduzido (Peso 50\%): Aplicações em Depósitos Interfinanceiros com Recursos Próprios, Aplicações em Depósitos de Poupança pelas Cooperativas de Crédito, Aplicações em Moedas Estrangeiras, Créditos Decorrentes de Repasses de Recursos a Outras Instituições Financeiras, Financiamentos Habitacionais;

- Risco Normal (Peso 100\%): Operações Vinculadas à Bolsas de Valores, de Mercadorias e de Futuros, Títulos Aceitos como Moeda de Privatização, Créditos Decorrentes de Transações com Correspondentes, Empréstimos e Títulos Descontados, Financiamentos, Financiamentos Rurais e Agroindustriais, Financiamentos de Títulos e Valores Mobiliários, Financiamento de Infra-estrutura e Desenvolvimento, Créditos Adquiridos que Contam com Coobrigação de Instituição Financeira, Operações de Créditos em Liqüidação, Arrendamentos a Receber, Subarrendamentos a Receber, Valores Residuais a Realizar, Créditos de Arrendamento Mercantil em Liquidação, Operações de Avais e Fianças Honradas, Operações de Câmbio, Rendas a Receber, Valores a Receber de Operações realizadas em Bolsas de Valores, Créditos Específicos da Caixa Econômica Federal-CEF e Banco Nacional de Desenvolvimento Econômico e Social-BNDES, Operações Especiais do Banco do Brasil com o Tesouro Nacional, Valores Específicos da CEF, Créditos Diversos, Outros Créditos em Liqüidação de 
Créditos Diversos, Investimentos Temporários em bens não de Uso Próprio, Ativo Permanente e Coobrigações e Riscos em Garantias Prestadas.

\subsection{População e Plano Amostral}

O sistema financeiro brasileiro é composto por uma população bastante heterogênea, porém com subpopulações homogêneas (estratos) bem definidas (os), que nos permitem obter os dados utilizando a técnica de amostragem estratificada.

Os estratos podem ser determinados das mais variadas formas, conforme a natureza do objeto pesquisado. No caso dos bancos, pode-se dividi-los, dentre outros, pelos seguintes seguimentos:

- Origem: nacional ou estrangeira;

- Tamanho: grande, médio ou pequeno;

- Região: norte, nordeste, centro-oeste, sudeste e sul.

Nesta dissertação, optamos pelas subpopulações correspondentes às regiões do País. Desta forma, foi extraída uma amostra de 10 instituições financeiras, que, ao serem subdividas pelas regiões com maior participação no setor financeiro, ficaram percentualmente assim distribuídas: Região Sudeste: 60\%; Região Nordeste: $20 \%$ e Região Sul: $20 \%$. Em termos de representatividade, os bancos selecionados possuíam, na posição de junho/95, 63,23\% do volume de ativos e $61,5 \%$ do patrimônio líquido dos 50 maiores bancos do sistema financeiro nacional. 
$\mathrm{Na}$ pesquisa foram utilizados como fonte de informação os Balancetes trimestrais ou os Balanços alusivos ao período de dezembro/94 a dezembro/96, sendo somente selecionadas instituições classificadas como bancos comerciais e múltiplos.

Os Bancos comerciais são instituições financeiras que recebem depósitos em contas de movimento (depósitos à vista), realizam empréstimos a curto e médio prazos, bem como prestam serviços auxiliares tais como cobrança, transferência de fundos, arrecadação de impostos etc.

Os bancos múltiplos foram criados pela Resolução $n^{\circ}$ 1524/88, com o objetivo de racionalizar a administração das instituições financeiras que atuavam em áreas distintas, porém pertencendo a um mesmo grupo empresarial. Embora possuindo carteiras específicas nas áreas comercial, de investimento, de desenvolvimento etc, podem contabilizar todas as operações como uma única instituição, apresentando um balanço consolidado com significativa redução de custos.

\subsection{Coleta e Tratamento dos Dados}

Os dados referentes às variáveis Patrimônio Líquido Ajustado (PLA) e Ativo Ponderado pelo Risco (Apr) dos bancos que constituíram a amostra, foram obtidos através do sistema de correio eletrônico do BACEN - SISBACEN, até o nível de consulta permitido, ou seja, de desdobramento de subgrupo (nível 3). Os valores alusivos ao PLA e ao Apr considerados apenas em Milhares de Reais (R\$ MIL) - corresponderam aos dados primários que alimentaram a planilha ALFA, cujo modelo apresentamos no anexo 2, e que nos permitiram o cálculo do Índice de Capitalização $(\mathrm{K})$ e o estudo da sua evolução através da utilização de gráficos. 


\section{CAPÍTULO IV}

\section{ANÁLISE DAS REGRAS DO ACORDO DA BASILÉIA}

No presente capítulo faremos uma análise mais aprofundada dos principais pontos tratados no Acordo da Basiléia e de determinados aspectos contábeis inerentes ao tema: Os Componentes do Capital, Classes de Risco, Risco de Transferência de País, Itens fora do Balanço, O Risco de Crédito dos Derivativos, A Contabilidade e o Controle dos Riscos, Índice Padrão e Metodologias de Mensuração dos Riscos de Mercado. Em cada tópico, citaremos o conteúdo das partes a serem analisadas, para, em seguida, discorrermos sobre determinados aspectos que julgamos relevantes. No final do capítulo, apresentaremos um quadro-resumo, extraído da obra de HALL, que coloca de forma didática as deficiências por ele verificadas no citado acordo, bem como as suas sugestões para serem estudadas em eventuais aperfeiçoamentos que no futuro possam existir.

\subsection{Os Componentes do Capital}

Quando trata da "nova definição de capital", o acordo o divide em dois tipos: restrito e amplo. A medida restrita, também denominada Tier 1(core ou capital essencial), consiste basicamente das ações ordinárias e lucros retidos, deduzidos do goodwill e dos investimentos em subsidiárias não consolidados nos sistemas nacionais. A medida ampla ou Tier 2 é igual à soma do capital essencial com o capital suplementar.

Mais recentemente, em janeiro de 1996, o Comitê da Basiléia emitiu um adendo ao Acordo firmado em 1988 - ampliando o conceito de capital -, no qual prevê uma nova 
categoria denominada Tier 3 (obrigações vinculadas de curto prazo) necessária para cobrir parte $^{12}$ dos riscos de mercado, estando sujeita às seguintes restrições:

- deverá ter vencimento original de pelo menos dois anos e será limitado a $250 \%$ do nível 1 de capital (Tier 1) do banco que estiver alocado para suportar o risco de mercado;

- é somente aceitável para cobrir os riscos de mercado, incluindo o risco de câmbio e o de commodities;

- até o ponto em que os limites globais do acordo de capital de 1988 não sejam violados, os elementos no nível 2 de capital (Tier 2) poderão ser substituídos pelo nível 3 (Tier 3) até o mesmo limite de 250\%;

- deverá estar sujeita a uma restrição, que impede o pagamento dos juros e/ou o principal nos casos em que este pagamento signifique o comprometimento do capital total do banco, tornando-o menor que as exigências mínimas de capital.

Relativamente ao capital suplementar, o acordo de 1988 prevê que podem ser incluídos:

- dívida subordinada: inclui instrumentos de capital de dívida subordinada convencionais não garantidos, com vencimento fixo original de mais de cinco anos e ações preferenciais resgatáveis de vida limitada. Este instrumento de captação não existe no Brasil;

12 A principal forma de capital elegível para cobrir os riscos de mercado consiste no patrimônio líquido e lucros acumulados (Tier 1) e capital suplementar (Tier 2), como definido no Acordo de Capital de 1988 (Análise e Controle do Risco de Derivativos). p. 6. 
- instrumentos híbridos de capital: inclui ações preferenciais perpétuas, ações preferenciais a longo prazo no Canadá, instrumentos de dívida perpétua no Reino Unido etc;

- reservas não publicadas: são incluídas apenas as reservas que, embora não divulgadas, tenham transitado pelo demonstrativo de resultado e são aceitas pelas autoridades supervisoras do banco. Tais reservas sofreram restrições (vide comentários subseqüentes);

- reserva de reavaliação: pode ser formal ou latente. A primeira é incorporada ao valor dos ativos fixos no balanço, enquanto que a segunda é decorrente de ativos registrados tradicionalmente a custo histórico, mas que a qualquer momento podem ser realizados a preços de mercado, sendo o lucro utilizado para compensar eventuais prejuízos;

- provisões gerais/reservas gerais para perdas em empréstimos: incluem provisões não destinadas a um ativo em particular.

Embora estivesse dentro da sua estrutura sob o título de Definição de Capital, na realidade, o acordo não trouxe uma nova definição nem sugeriu uma mais abrangente, a ponto de tornar claro este termo. O acordo optou por sugerir duas categorias de capital, relacionando os elementos que podem compô-las. Existiu uma preocupação óbvia em aceitar, em princípio, somente os itens que estivessem permanentemente disponíveis para absorver perdas, evitar insolvência, falta de liquidez e, conseqüentemente, desconfiança por parte dos depositantes (capital básico). 
Contudo, a característica de solvência inerente ao capital varia enormemente de país para país, devido à diversidade de práticas contábeis neles existentes, dos aspectos relacionados com a inflação, dos instrumentos híbridos de capital etc. Em decorrência de tal fato, o Comitê admite a inclusão também como capital, desde que sujeitos a algumas restrições, dos itens formadores do capital suplementar.

A dívida subordinada, por exemplo, possui vencimento fixo e impossibilidade de absorver perdas, exceto na hipótese de liqüidação. Tal característica, conforme prevê o Acordo da Basiléia, a impossibilita de fazer parte do capital básico, limitando-a a $50 \%$ do mesmo. Esta dívida é uma forma alternativa de captação de recursos a longo prazo, utilizada nos países como Canadá, França, Suíça, Reino Unido e Estados Unidos, sendo, quando de sua emissão, subordinada aos direitos dos depositantes por determinação das autoridades supervisoras. Para REED e GILL:

A subordinação faz com que a dívida atenda à mesma função de proteção que o patrimônio líquido (equity) do ponto de vista dos depositantes (1994, p.203).

No Brasil, as captações de recursos a longo prazo, através da emissão de títulos representativos de dívidas, podem ser na forma de aceites cambiais, letras imobiliárias, hipotecárias e debêntures, todas enquadradas no exigível, embora possuam natureza semelhante à dívida subordinada. Tal fato, limita o poder de alavancagem dos bancos que possuem recursos desta espécie.

Já os instrumentos híbridos de capital possuem características que os qualificam como títulos patrimoniais e títulos de dívida, podendo, quando necessário, absorver perdas sem a necessidade de negociá-los. No Brasil, embora as debêntures conversíveis em ações 
(títulos de dívida passíveis de serem convertidos em títulos patrimoniais) possuam estas características, o BACEN não as enquadra como componente do capital, reduzindo, também, a possibilidade de alavancagem das instituições financeiras.

As reservas não publicadas, embora possuam as mesmas qualidades inerentes às dos lucros retidos publicados, devido à falta de transparência, não poderiam ser consideradas como capital básico, mesmo porque tornar-se-ia impossível uma comparabilidade deste elemento entre os países. A sua constituição poderia ser realizada de diversas formas, de acordo com o regime de contabilidade de cada país.

Ao fazer a comparação dos elementos que constituem o capital suplementar no Reino Unido, no Japão e nos Estados Unidos, HALL esclarece que as reservas não publicadas somente estariam presentes no sistema contábil do Reino Unido (undisclosed reserves) e, mesmo assim, com a seguinte limitação:

Undisclosed reserves will only be allowed until the end of 1992, in accordance with the EC's Bank Accounts Directive, de 1986 (1994, p.174).

No caso da reavaliação, cuja técnica é adotada apenas por determinados países sendo um fator limitante da comparabilidade - , o produto resultante, seja formal ou latente, é aceito como base de capital somente se forem adotados critérios prudentes, ou seja, que reflitam na totalidade as chances de flutuação de preço e de venda forçada, e que sejam aceitos pela autoridade supervisora. Especificamente com relação às reservas latentes, a sua inclusão como capital suplementar é admitida - uma vez que as mesmas podem ser utilizadas para absorver perdas - , desde que se adote um desconto $(55 \%$ da diferença entre o valor 
histórico e o valor de mercado) que reflita a volatilidade do mercado, bem como as despesas tributárias relativas aos ganhos realizados.

O tema "reavaliação" foi objeto de um Pronunciamento do IBRACON, aprovado pela CVM através da Deliberação $n^{0}$ 183, de 19 de junho de 1995, o qual tem como objetivo, segundo aquela entidade: "adaptar o pronunciamento anterior às normas internacionais de contabilidade, bem como à própria evolução desse tema no Brasil”. Dentre os seus principais pontos, teceremos alguns comentários sobre os seguintes:

- restrição do uso da avaliação apenas para os bens tangíveis do ativo imobilizado, desde que não esteja prevista a sua descontinuidade operacional;

Comentário: Desta restrição decorre que a reavaliação a ser considerada como capital nos bancos brasileiros, limitar-se-á à realizada formalmente e mesmo assim somente àquelas realizadas sobre os bens tangíveis do ativo imobilizado. A reavaliação latente (títulos e valores contabilizados ao preço de aquisição, e não da avaliação do mercado), prevista no Acordo da Basiléia, não é computada no caso brasileiro. Na Resolução 2099, o BACEN admitiu a inclusão dos valores correspondentes à reserva formal de reavaliação como capital, uma vez que os mesmos compõem o patrimônio líquido ajustado.

- adoção de periodicidade anual, para as contas sujeitas a variações significativas;

Comentário: a obrigatoriedade de reavaliação anual dos bens sujeitos a grandes oscilações de preço implicará na manutenção de saldos crescentes na contas de reserva de reavaliação, o que auxiliará os bancos no cálculo do índice de capitalização (PLA crescente). 
- o reconhecimento da carga tributária no momento do registro da reavaliação, a ser apropriada quando das realizações;

Comentário: o registro da carga tributária em uma conta retificadora da reserva de reavaliação reduzirá o efeito alavancador da reserva de reavaliação.

- impossibilidade de utilizar a reserva de reavaliação para aumento de capital ou amortização de prejuízo enquanto não realizada.

Comentário: Em termos econômicos, a reserva de reavaliação só poderia ser considerada como capital, no momento de sua realização. Antes disso, é utilizar-se de um potencial de ganho para fazer face a eventuais perdas, o que tecnicamente não é aceito. O Acordo da Basiléia, ao admitir a citada reserva como capital suplementar, refere-se ao aspecto da realização apenas para as reservas latentes, mesmo assim reduzindo-as (a título de prudência) com um desconto de 55\% sobre a diferença entre o valor histórico e o valor de mercado. Quanto às reservas formais não é mencionado nenhum desconto, o que subtende a sua consideração na totalidade como capital suplementar, o que corresponde uma falha, pois somente deveria ser reconhecida como tal, por ocasião de sua realização.

Finalmente, no que se refere às provisões gerais/reservas gerais contra perdas em empréstimos, dada a dificuldade de diferenciá-las das provisões constituídas para cobrir perdas sobre determinados ativos, o comitê chegou à conclusão de que as mesmas deveriam se restringir ao montante equivalente a $1,25 \%$ do total dos ativos de risco. Neste ponto, é importante tecermos alguns comentários sobre a diferença existente entre esses dois termos, reportando-nos ao que dispõe o Manual de Contabilidade das Sociedades por Ações (1990, pp.409-410): 
- Provisão: "são reduções de ativos ou acréscimos de exigibilidades que reduzem o patrimônio líquido, e cujos valores não são ainda totalmente definidos” ou “perdas economicamente incorridas ou prováveis valores a desembolsar originados de fatos já acontecidos";

- Reserva: "são parcelas que representam a diferença entre o patrimônio líquido e o capital, se positivas". "Não têm nenhuma característica de exigibilidade imediata ou remota".

Das definições acima, depreende-se que: os valores provisionados já têm finalidade específica, ou seja, destinam-se ao reconhecimento de uma perda já incorrida ou à transformação de parte do patrimônio líquido em exigível. No caso das provisões gerais previstas no Acordo da Basiléia, em virtude das mesmas não estarem vinculadas nem a uma perda específica, nem a uma exigibilidade, em termos econômicos, poderiam estar enquadradas totalmente na qualidade de capital. O Comitê, adotando uma postura conservadora, limitou-as a $1,25 \%$ do total dos ativos de risco, conforme já mencionado. A literatura pesquisada, ora se refere à expressão "provisões gerais" ora se refere a "reservas gerais", ambas, porém, possuindo a essência do capital, isto é, estão disponíveis para absorver eventuais perdas, em virtude de não estarem vinculadas especificamente a despesas já incorridas ou a exigibilidades.

No Brasil, a Resolução 2099 do CMN não adotou a classificação estabelecida pelo Acordo da Basiléia (Capital dividido em três categorias) referindo-se somente à expressão "patrimônio líquido ajustado na forma da regulamentação em vigor" (vide item 3.2) como base de cálculo para os limites operacionais exigidos para os bancos brasileiros. No patrimônio líquido ajustado não se encontra, dentre os seu elementos formadores, a provisão 
para créditos de difícil liquidação. Tal provisão é constituída para fazer face às perdas incorridas oriundas dos créditos vencidos e não pagos, tendo, portanto, um vínculo prédeterminado, não podendo conseqüentemente ser considerada como capital.

\subsection{Classes de Risco}

Com o objetivo de classificar os riscos inerentes a cada ativo, o comitê estabeleceu uma metodologia de índice por peso, dividindo o ativo em cinco categorias de risco $(0,10$, 20, 50 e 100 por cento), cuja exigência de capital estaria vinculada diretamente à classe de risco à qual o ativo estivesse enquadrado. Com esse procedimento, aquele organismo achava que poderia obter: base mais justa para comparações internacionais; incorporação dos riscos oriundos de atividades fora do balanço; nenhum impedimento com relação aos bancos com ativos de baixo risco.

É neste ponto onde recaem as maiores críticas. Inicialmente porque o acordo limitava-se à avaliação do risco de crédito, justificando que o mesmo é o principal risco de um banco. Somente em janeiro de 1996, o Comitê emitiu um suplemento ao acordo de 1988, incluindo a exigência de capital para suportar os riscos com derivativos.

A respeito do risco de crédito, convém ressaltar a crítica de HALL (1994, p.271) ao analisar a visão restrita do acordo, em detrimento de uma visão mais abrangente de risco:

Of the deficiencies identified, probably the most important is that relating to the adoption of a spurious methodological approach to the assessment of portfolio risk. Overlooking, for now, the fact that risks other than credit risks are largely ignored, it remains the case that overall portfolio risk is 
rarely the simple sum of individual on-balance-sheet and off-balance-sheet risks that the G-10 approach assumes. Rather, standard portfolio theory (Tobin, 1965) teaches us that portfolio risk (measured as the variance in returns) depends, inter alia, on the variance of expected returns for the individual assets and on the correlations between those expected returns.

Aquele autor chega até a afirmar que:

A metodologia defendida pelo G-10 é incompleta e conseqüentemente incapaz de assegurar uma solvência estável dos bancos.

HALL (1994,p.278) se posiciona contra o processo simplista adotado pelo Comitê, que além de se limitar ao risco de crédito, induz ao entendimento incorreto de que o risco de todo o portfólio de um banco se resumiria apenas à soma dos riscos atribuídos a cada categoria. Para ele:

Dever-se-ia analisar os ativos individualmente, a fim de verificar a variabilidade dos seus retornos esperados e a correlações existentes entre eles. Na prática, porém, esta técnica só é possivel de ser realizada por especialistas no gerenciamento de ativos, por disporem dos dados relativos às taxas de juros, aos prazos, à qualidade dos ativos, às probabilidades de reembolsos etc.

Outro ponto que podemos destacar é que os próprios fatores de ponderação $(0,10,20$, 50 e 100\%), por si sós, já são arbitrários, uma vez que não tomam por base os princípios da Teoria de Finanças. Dado que o principal foco é sobre o risco de crédito, ficava claro que o 
conjunto de pesos estabelecidos não contemplava todas as atividades de um banco. Por exemplo, as atividades voltadas para a concessão de empréstimos aos governos, às entidades do setor público, ao setor privado, dentre outros, todas estão contempladas com os seus respectivos pesos, porém, aquelas relacionadas aos investimentos em títulos e valores mobiliários, às operações de câmbio, aos derivativos etc, ficavam a critério dos órgãos supervisores incluí-las ou não.

No caso específico do Brasil, na Resolução $n^{0} 2099$ foram utilizados critérios adicionais que possibilitaram a classificação dos ativos em quatro categorias $(0,20,50$ e 100\%), dentro das quais levou-se em consideração os aspectos relacionados à modalidade operacional, à liquidez, à volatilidade, às garantias etc. Esta visão mais abrangente, considerando outros fatores além do risco de crédito, proporcionou, por exemplo: a inclusão das aplicações em ouro e das disponibilidades em moedas estrangeiras na categoria de 20\%; a atribuição de pesos distintos para os títulos do governo federal e municipal; o enquadramento na categoria de $100 \%$ aos créditos de qualquer natureza, com exceção dos empréstimos imobiliários; etc.

Um aspecto importante a ressaltar no caso brasileiro é que os créditos aos governos (federal, estadual e municipal) ou às entidades a eles vinculadas se equiparam na mesma categoria de 100\% (no Acordo da Basiléia tais créditos se enquadram na categoria de 0\%). Tal linearidade exigirá mais aporte de capital para os bancos inseridos nas políticas globais de desenvolvimento, no momento em que o país retomar os seus investimentos, notadamente nas áreas de infra-estrutura, saúde e educação. 


\subsection{Risco de Transferência de País}

No início, houve uma dificuldade para se criar uma metodologia satisfatória que incorporasse esse tipo de risco na estrutura de medição. Foram propostas duas sistemáticas: a primeira consistia na diferenciação entre créditos contra instituições internas (governo central, setor público e bancos) e créditos contra os países estrangeiros; a segunda, selecionava os países por grupos considerados de boa ou má situação de crédito.

Prevaleceu a segunda sistemática. Desta forma, o comitê separa os países por ele considerados de alto risco, com a justificativa de que o risco de transferência varia enormemente de país para país e que, dada a sua magnitude, não pode ser aferido simplesmente pelo critério de crédito interno ou externo com referência a determinado país. Outro argumento, favorável à segunda opção, foi o fato de a Comunidade Econômica Européia exigir que todos os seus membros deveriam ser tratados de uma única forma. Deste modo, foi formado um grupo denominado $\boldsymbol{O C D E}$, composto pelos próprios membros efetivos da Organização para Cooperação e Desenvolvimento Econômico (OCDE) ou de países que tivessem obtido condições especiais de empréstimos junto ao Fundo Monetário Internacional (FMI).

Em decorrência da escolha acima, a classificação dos pesos para os casos de risco de transferência de país ficou assim especificada:

- créditos contra governos centrais da OCDE: peso zero (ou um baixo peso se a autoridade supervisora decidir incorporar o risco de taxa de juros); 
- créditos contra entidades da OCDE pertencentes ao setor público (governos estaduais, autoridades locais etc.), que não sejam do governo central: pesos baixos, variando de 0 a 50\%, com exceção das empresas comerciais, que têm um peso de $100 \%$;

- créditos contra governos centrais e bancos centrais externos à OCDE, desde que estejam denominados em moeda nacional e cujos passivos correspondentes estejam na mesma moeda: peso zero (ou um baixo peso se a autoridade supervisora decidir incorporar o risco de taxa de juros);

- créditos contra bancos de qualquer nacionalidade, com maturidade de até um ano inclusive: $20 \%$;

- créditos a prazos mais longos contra bancos incorporados na OCDE: 20\%;

- créditos a prazos mais longos contra bancos externos à OCDE: $100 \%$.

Pelos argumentos e pela classificação acima apresentados, verifica-se que predominou um certo corporativismo na atribuição de baixos pesos aos créditos contra governos, entidades públicas e bancos pertencentes à OCDE. Não se procedeu, portanto, a uma análise individual de cada país, dos governos ou das entidades a eles vinculadas (que captam e emprestam recursos no mercado internacional), considerando os seguintes aspectos:

- econômicos: estabilidade monetária, balança de pagamento, nível de endividamento etc;

- financeiros: posição das reservas cambiais e capacidade de pagamento; 
- contábeis: o sistema contábil vigente no país e seus efeitos nos demonstrativos financeiros;

- políticos: estabilidade política e institucional do país.

\subsection{Itens fora do Balanço}

Os diversos tipos de negócios praticados pelos bancos, e ainda não incluídos nos seus balanços, foram analisados e inseridos dentro da proposta para convergência dos padrões de capital, numa tentativa de que aquelas instituições aportem também um capital mínimo, o suficiente para cobrir os riscos de crédito correspondentes.

Contudo, o Comitê reconheceu, dado o caráter inovador de tais operações, a dificuldade para avaliar os respectivos riscos, bem como em justificar a utilização de controles complexos, em alguns países, diante do pequeno volume de operações da espécie. A posição adotada pelo comitê foi a seguinte: todas as categorias de negócios fora do balanço serão convertidas a equivalentes de risco de crédito através da multiplicação do valor nominal do principal por um fator de conversão de crédito, sendo os resultados pesados de acordo com a natureza da outra parte.

O comitê dividiu as atividades fora do balanço em cinco categorias (trataremos sobre derivativos no item 4.5 seguinte), dando um certo grau de liberdade para se incluir, dentro de uma dessas subdivisões, os instrumentos com características específicas de cada mercado. Relacionamos, a seguir, as referidas categorias, com os esclarecimentos necessários sobre os seus principais instrumentos, conforme o relatório "A administração dos riscos de crédito 
fora do balanço dos bancos: uma perspectiva da supervisão", publicado pelo Comitê da Basiléia, em março de 1986:

1. substitutos para empréstimos, com fator de conversão de risco de crédito de $100 \%$ : garantias gerais de endividamento, aceites bancários e cartas de crédito standby que servem como garantias financeiras sobre empréstimos e títulos;

- garantias e aceites: são obrigações com a finalidade de dar sustentação a terceiros. São consideradas substitutos diretos de crédito com risco equivalente ao de um empréstimo para um tomador final ou para o sacador de um instrumento no caso de aceite;

- cartas de crédito standby: uma obrigação, por parte do banco, perante um beneficiário designado, de cumprir ou fornecer pagamento nos termos dos contratos básicos a que se refere, no caso de cliente do banco deixar de fazê-lo.

2. certos itens contingentes relacionados às transações, com fator de conversão de risco de crédito de $50 \%$ : cartas de fiança;

- cartas de fiança: em princípio, são muito parecidas com as garantias gerais no aspecto de que o risco de crédito depende da capacidade de um terceiro (o cliente do banco) cumprir suas obrigações. Mas, de uma forma geral, não são substitutos diretos de crédito. Elas não garantem uma obrigação financeira existente, mas a capacidade de um cliente em atender a suas obrigações rotineiras de negócios e, às vezes, estão relacionadas com contratos específicos. 
3. passivos contingentes de curto prazo, auto-liquidáveis, oriundos de transações com mercadorias, com fator de conversão de risco de crédito de $20 \%$ : créditos documentários garantidos pelos embarques a eles relacionados;

- créditos documentários: carta de crédito garantindo o pagamento pelo banco emitente em favor de um exportador contra a apresentação de documentos de embarque e outros.

4. compromissos com vencimento original acima de um ano, as linhas de crédito com emissão de notas (NIFs) e as linhas rotativas para subscrição (RUFs), com fator de conversão de risco de crédito de $50 \%$;

- compromissos com vencimento original acima de um ano: um banco se compromete com uma transação futura que normalmente resultará na aquisição, pelo banco, de um risco de crédito, em alguma data no futuro. Exemplo: venda de ativos e acordos de recompra: um acordo pelo qual o banco vende um empréstimo, título ou ativo fixo a um terceiro com o compromisso de recomprar o ativo depois de certo período ou na ocorrência de determinada contingência;

- linhas de crédito com emissão de notas e linhas rotativas para subscrição: um acordo pelo qual o tomador poderá sacar fundos até um limite determinado, durante um período prolongado, por meio de várias emissões no mercado de, por exemplo, notas promissórias de três ou seis meses. Se, a qualquer momento, as notas não puderem ser colocadas no mercado por um preço mínimo, o banco subscritor se compromete a comprá-las por um preço pré-determinado. 


\subsection{O Risco de Crédito dos Derivativos}

Os itens relacionados a taxas de juros e câmbio (swap, opções, futuros), por não ficarem expostos aos riscos de crédito pelo valor nominal do contrato, possuem um tratamento especial, no qual se prevê um custo potencial de substituição do fluxo de caixa, caso a contraparte inadimplir. São os seguintes os métodos propostos:

\section{Exposição Atual (Current Exposure):}

- os bancos calculariam o custo de reposição de todos os contratos com valor positivo, ou seja, o valor de cada contrato registrado a preço de mercado (mark to market), normalmente apurado na posição do último dia útil do mês; e

- adicionaria uma quantia correspondente ao potencial futuro de risco de crédito, baseada no valor do principal ponderado de acordo com o prazo a decorrer de cada operação, conforme segue:

TABELA I

CONSTANTE NO ACORDO DE JULHO DE 1988 (*).

\begin{tabular}{|l|c|c|}
\hline \multicolumn{1}{|c|}{ Prazo Residual } & Taxa de Juros & Taxa de Câmbio \\
\hline Menos de um ano & 0 & $1,0 \%$ \\
\hline Um ano e mais & $0,5 \%$ & $5 \%$ \\
\hline
\end{tabular}

(*) Modificada pela Tabela II abaixo. 
Em janeiro de $1996^{13}$, o Comitê da Basiléia modificou as séries de vencimentos residuais da matriz de julho de 1988, divulgando uma nova tabela na qual constam, também, novos tipos de contratos, conforme segue:

\author{
TABELA II
}

CONSTANTE NO SUPLEMENTO DE JANEIRO DE 1996

\begin{tabular}{|l|c|c|c|c|c|}
\hline \multicolumn{1}{|c|}{ Prazo Residual } & $\begin{array}{c}\text { Taxa } \\
\text { de } \\
\text { Juros }\end{array}$ & $\begin{array}{c}\text { Taxa } \\
\text { de } \\
\text { Câmbio }\end{array}$ & $\begin{array}{c}\text { Valores } \\
\text { Mobiliários }\end{array}$ & $\begin{array}{c}\text { Metais } \\
\text { Preciosos } \\
\text { exceto } \\
\text { Ouro }\end{array}$ & $\begin{array}{c}\text { Outras } \\
\text { Commodities }\end{array}$ \\
\hline Um ano ou menos & $0,0 \%$ & $1,0 \%$ & $6,0 \%$ & $7,0 \%$ & $10,0 \%$ \\
\hline $\begin{array}{l}\text { Acima de um ano até } \\
\text { cinco anos }\end{array}$ & $0,5 \%$ & $5 \%$ & $8,0 \%$ & $7,0 \%$ & $12,0 \%$ \\
\hline Acima de cinco anos & $1,5 \%$ & $7,5 \%$ & $10,0 \%$ & $8,0 \%$ & $15,0 \%$ \\
\hline
\end{tabular}

O Método de Exposição Atual foi considerado pelo Comitê como o melhor dentre as alternativas por ele oferecidas. Os bancos que negociam contratos a termo, de swap, opções ou outros contratos com derivativos baseados em valores mobiliários, metais preciosos, com exceção do ouro, ou outras commodities, deverão aplicar este método.

No Brasil, o Conselho Monetário Nacional, através da Resolução n ${ }^{0}$ 2399, de 25 de junho de 1997, e das Circulares no 2770/97 e 2771/97 determinou que os bancos utilizassem tal metodologia ${ }^{14}$, a fim de estimar o risco de crédito das operações com derivativos, efetuando as devidas adaptações às operações usuais e às características do mercado financeiro brasileiro.

13 Embora os bancos tenham tomado conhecimento desta modificação deste abril de 1995, o Comitê da Basiléia só oficializou o Adendo ao Acordo de 1988, em janeiro de 1996 (Federal Reserve Bulletin, março de 1996, p. 220).

14 Esta sistemática entrou em vigor a partir de agosto/97, porém as instituições terão até o final do ano para se enquadrar às novas regras. 
Tais adaptações consistem na marcação dos derivativos (especificamente operações de swap) a valor de mercado, com base nas informações divulgadas regularmente pelo Banco Central do Brasil, utilizando-se de uma amostra de cerca de 30 instituições. Após realizada, pelos bancos, a avaliação a preço de mercado, os contratos com valor positivo deverão ser contabilizados no subtítulo adequado "valor de mercado positivo de swap", os quais serão considerados na categoria de ativos com fator de ponderação de $100 \%$, conforme previsto na Resolução n 2099.

$\mathrm{Na}$ exposição futura, o risco de crédito dos derivativos $\left(\mathrm{RCD}_{\mathrm{i}}\right)$ será medido pela multiplicação do valor inicial do contrato por um fator de risco potencial que considera o prazo a transcorrer, as volatilidades de cada uma das pontas da operação e o coeficiente de correlação entre os referenciais ativos e passivos, apresentados conforme a fórmula e as tabelas abaixo:

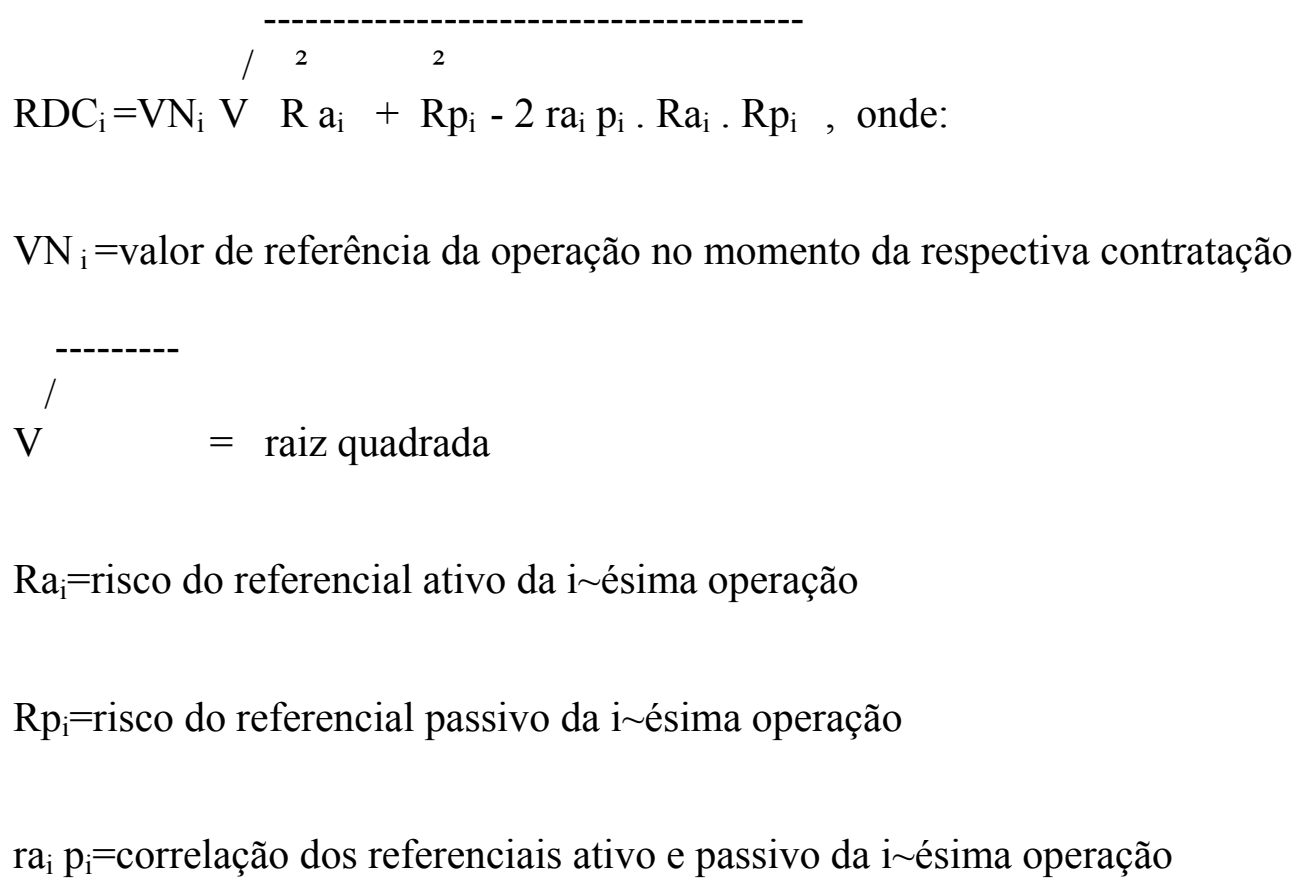




\begin{tabular}{|c|c|c|c|c|c|c|c|c|c|}
\hline \multicolumn{10}{|c|}{$\begin{array}{l}\text { TABELA I } \\
\text { FATORES DE RISCO DOS REFERENCIAIS ATIVOS E PASSIVOS APLICÁVEIS ÀS OPERAÇÕES DE } \\
\text { "SWAP" }\end{array}$} \\
\hline PRAZO & CDI & $\begin{array}{l}\text { DÓL } \\
\text { COM }\end{array}$ & $\begin{array}{l}\text { DÓL } \\
\text { FLU }\end{array}$ & OURO & ÍNDICE & $\begin{array}{r}\text { TR/ } \\
\text { TBP }\end{array}$ & ANBID & SELIC & OUTROS \\
\hline 30 & 0,0020 & 0,0084 & 0,0084 & 0,0408 & 0,0228 & & 0,0018 & 0,0020 & 0,0202 \\
\hline 60 & 0,0034 & 0,0132 & 0,0132 & 0,0576 & 0,0323 & 0,0029 & 0,0031 & 0,0034 & 0,0286 \\
\hline 90 & 0,0058 & 0,0152 & 0,0152 & 0,0706 & 0,0395 & 0,0050 & 0,0052 & 0,0058 & 0,0350 \\
\hline 120 & 0,0108 & 0,0196 & 0,0196 & 0,0803 & 0,0449 & 0,0094 & 0,0097 & 0,0108 & 0,0404 \\
\hline 150 & 0,0160 & 0,0240 & 0,0240 & 0,0901 & 0,0504 & 0,0137 & 0,0144 & 0,0160 & 0,0452 \\
\hline 180 & 0,0210 & 0,0284 & 0,0284 & 0,0998 & 0,0559 & 0,0180 & 0,0189 & 0,0210 & 0,0495 \\
\hline 210 & 0,0316 & 0,0346 & 0,0346 & 0,1067 & 0,0598 & 0,0270 & 0,0284 & 0,0316 & 0,0535 \\
\hline 240 & 0,0420 & 0,0410 & 0,0410 & 0,1136 & 0,0636 & 0,0360 & 0,0378 & 0,0420 & 0,0572 \\
\hline 270 & 0,0526 & 0,0472 & 0,0472 & 0,1205 & 0,0675 & 0,0448 & 0,0473 & 0,0526 & 0,0606 \\
\hline 300 & 0,0630 & 0,0534 & 0,0534 & 0,1274 & 0,0714 & 0,0538 & 0,0567 & 0,0630 & 0,0639 \\
\hline 330 & 0,0736 & 0,0598 & 0,0598 & 0,1343 & 0,0752 & 0,0628 & 0,0662 & 0,0736 & 0,0670 \\
\hline 360 & 0,0840 & 0,0660 & 0,0660 & 0,1412 & 0,0791 & 0,0718 & 0,0756 & 0,0840 & 0,0700 \\
\hline 390 & 0,0868 & 0,0682 & 0,0682 & 0,1461 & 0,0818 & 0,0743 & 0,0781 & 0,0868 & 0,0729 \\
\hline 420 & 0,0898 & 0,0706 & 0,0706 & 0,1509 & 0,0846 & 0,0769 & 0,0808 & 0,0898 & 0,0756 \\
\hline 450 & 0,0926 & 0,0728 & 0,0728 & 0,1559 & 0,0872 & 0,0892 & 0,0833 & 0,0926 & 0,0783 \\
\hline 480 & 0,0956 & 0,0752 & 0,0752 & 0,1607 & 0,0900 & 0,0817 & 0,0860 & 0,0956 & 0,0808 \\
\hline 510 & 0,0984 & 0,0774 & 0,0774 & 0,1656 & 0,0927 & 0,0842 & 0,0886 & 0,0984 & 0,0833 \\
\hline 540 & 0,1014 & 0,0796 & 0,0796 & 0,1704 & 0,0955 & 0,0868 & 0,0913 & 0,1014 & 0,0857 \\
\hline 570 & 0,1042 & 0,0820 & 0,0820 & 0,1753 & 0,0981 & 0,0891 & 0,0938 & 0,1042 & 0,0881 \\
\hline 600 & 0,1072 & 0,0842 & 0,0842 & 0,1802 & 0,1009 & 0,0916 & 0,0965 & 0,1072 & 0,0904 \\
\hline 630 & 0,1100 & 0,0866 & 0,0866 & 0,1851 & 0,1036 & 0,0941 & 0,0990 & 0,1100 & 0,0926 \\
\hline 660 & 0,1130 & 0,0888 & 0,0888 & 0,1899 & 0,1064 & 0,0967 & 0,1017 & 0,1130 & 0,0948 \\
\hline 690 & 0,1158 & 0,0910 & 0,0910 & 0,1948 & 0,1091 & 0,0990 & 0,1042 & 0,1158 & 0,0969 \\
\hline 720 & 0,1188 & 0,0934 & 0,0934 & 0,1997 & 0,1119 & 0,1015 & 0,1069 & 0,1188 & 0,0990 \\
\hline \multicolumn{10}{|c|}{$\begin{array}{c}\text { TABELA II } \\
\text { COEFICIENTES DE CORRELAÇÃO }\end{array}$} \\
\hline & CDI & $\begin{array}{l}\text { DÓLC } \\
\text { OM }\end{array}$ & $\begin{array}{l}\text { DÓL } \\
\text { FLU } \\
\end{array}$ & OURO & ÍNDICE & TR & ANBID & SELIC & OUTROS \\
\hline CDI & 1,0 & 0,3 & 0,3 & 0,2 & 0,4 & 0,8 & 0,8 & 1,0 & 0 \\
\hline DÓL COM & 0,3 & 1,0 & 0,95 & 0,3 & 0,2 & 0,3 & 0,3 & 0,3 & 0 \\
\hline DÓL FLU & 0,3 & 0,95 & 1,0 & 0,3 & 0,2 & 0,3 & 0,3 & 0,3 & 0 \\
\hline OURO & 0,2 & 0,3 & 0,3 & 1,0 & 0,1 & 0,2 & 0,2 & 0,2 & 0 \\
\hline ÍNDICE & 0,4 & 0,2 & 0,2 & 0,1 & 1,0 & 0,4 & 0,4 & 0,4 & 0 \\
\hline TR/TBF & 0,8 & 0,3 & 0,3 & 0,2 & 0,4 & 1,0 & 0,7 & 0,8 & 0 \\
\hline ANBID & 0,8 & 0,3 & 0,3 & 0,2 & 0,4 & 0,7 & 1,0 & 0,8 & 0 \\
\hline SELIC & 1,0 & 0,3 & 0,3 & 0,2 & 0,4 & 0,8 & 0,8 & 1,0 & 0 \\
\hline OUTROS & 0 & 0 & 0 & 0 & 0 & 0 & 0 & 0 & 0 \\
\hline
\end{tabular}


2. Exposição Original (Original: Exposure):

- neste método, o banco aplica ao valor do principal de cada instrumento um dos dois conjuntos de fatores de conversão seguintes, conforme a natureza e o prazo de vencimento de cada um:

\section{TABELA III}

CONSTANTE NO ACORDO DE JULHO DE 1988 (*).

\begin{tabular}{|l|c|c|}
\hline \multicolumn{1}{|c|}{ Vencimento } & $\begin{array}{c}\text { Contratos de Taxa de } \\
\text { Juros }\end{array}$ & $\begin{array}{c}\text { Contratos de Taxa de } \\
\text { Câmbio }\end{array}$ \\
\hline Menos de um ano & $0,5 \%$ & $2,0 \%$ \\
\hline Um ano e menos de dois anos & $1,0 \%$ & $6,0 \%($ i.e. $2 \%+4 \%)$ \\
\hline Para cada ano adicional & $1,0 \%$ & $4,0 \%$ \\
\hline
\end{tabular}

(*) Modificada pela Tabela IV abaixo. 
Em janeiro de 1996, o Comitê da Basiléia modificou as séries de vencimentos da matriz acima, divulgando uma nova tabela na qual inclui o contratos de derivativos baseados em ouro, conforme segue:

TABELA IV

CONSTANTE NO SUPLEMENTO DE JANEIRO DE 1995.

\begin{tabular}{|l|c|c|}
\hline \multicolumn{1}{|c|}{ Vencimento } & $\begin{array}{c}\text { Contratos de Taxa de } \\
\text { Juros }\end{array}$ & $\begin{array}{c}\text { Contratos de Taxa de } \\
\text { Câmbio e Ouro }\end{array}$ \\
\hline Menos de um ano & $0,5 \%$ & $2,0 \%$ \\
\hline Um ano e menos de dois anos & $1,0 \%$ & $5,0 \%($ i.e. $2 \%+3 \%)$ \\
\hline Para cada ano adicional & $1,0 \%$ & $3,0 \%$ \\
\hline
\end{tabular}

O Método da Exposição Original foi considerado pelo Comitê como uma técnica mais simples, comparativamente ao da Exposição Atual. Este método prevê a sua utilização para contratos de taxas de juros, de câmbio e de ouro, sobre os quais é atribuída uma quantia de capital como suporte para cobrir os risco de crédito potencial, não se utilizando do valor de mercado, em uma determinada data, como critério de avaliação. A instituição financeira só poderá utilizar este método até que as exigências de capital relacionadas a risco de mercado sejam implementadas.

No Brasil, o Conselho Monetário Nacional vem adotando medidas que se adequam às exigências constantes do Acordo da Basiléia. Para tanto divulgou normativos que determinam ao mercado financeiro brasileiro observar alguns procedimentos para se aferir o 
risco de crédito dos derivativos, através da Resolução no 2399/97 e Circulares 2770/97 e 2771/97. Além disso, para se prevenir contra os riscos de mercado, emitiu a Resolução no 2.149/95, na qual enumera as operações de liquidação futura passíveis de serem realizadas em balcão, bem como exige, dentre outras obrigações, a indicação, pela instituição financeira, de diretor estatutário, tecnicamente qualificado, para ser responsável junto ao Banco Central do Brasil.

ALEXANDER (1988, p. 11) sugere alguns procedimentos que devem ser adotados a fim de proteger convenientemente os bancos dos riscos inerentes às atividades fora do balanço:

- um processo formal para aprovar todos os novos produtos financeiros antes que sejam usados. Tal processo deveria incluir uma avaliação do aspecto contábil, tributário e jurídico, a fim de assegurar que toda a gama de risco relativo a cada instrumento seja entendido;

- Uma política definida sobre cada produto financeiro. A política deveria definir a natureza da transação; fornecer uma avaliação detalhada do risco envolvido; os parceiros com os quais o banco realizará o negócio; bem como os indivíduos que efetivamente podem participar em tais transações e os seus respectivos limites;

- Um especialista na área de crédito, responsável pela avaliação dos riscos e desenvolvimento de políticas que regulem as transações. $\mathrm{O}$ especialista também deveria monitorar e assegurar o cumprimento dessas políticas.

- Um mecanismo através do qual um fator de risco possa ser atribuído para cada tipo de transação, de acordo com a contraparte da negociação. Diante da 
diversidade dos produtos bancários hoje existentes, é sempre uma tarefa difícil para o banco descobrir mecanismos que evidenciem quais riscos ele tem relativamente à contraparte da operação. Através da atribuição de fatores de risco, um banco estará mais habilitado a avaliar o seu risco total;

- Um bom relacionamento de trabalho com os auditores. Os auditores podem assegurar a adequação dos procedimentos operacionais implementados. Um banco que estabelece estreita ligação com os seus auditores se defrontará com poucas surpresas.

Dentre os procedimentos acima relacionados por ALEXANDER, existe uma lacuna, ao nosso ver, no que se refere ao aspecto econômico, ou seja, à apuração do resultado dos eventos relacionados aos itens fora do balanço. Entendemos que, da mesma forma como em qualquer outro evento, deve-se identificar, com clareza, a(s) entidade(s) dentro do banco que realiza(m) tais transações, os gestores responsáveis, os custos e as receitas variáveis, a margem de contribuição, os custos fixos e o resultado correspondente. Com base nesses parâmetros, pode-se avaliar o desempenho das áreas e viabilizar os ajustes necessários, nos casos em que ocorram resultados desfavoráveis.

\subsection{A Contabilidade e o Controle dos Riscos}

Nos grandes bancos dos países desenvolvidos, as operações fora do balanço têm representado uma alternativa importante para a obtenção de resultados favoráveis, sem a necessidade de se disponibilizarem grandes quantias de capital. A demanda no mercado financeiro por estes produtos tem sido intensa devido à forte competição entre os provedores de recursos da economia, que sempre estão dispostos a buscar fontes de recursos a custos os 
mais baixos possíveis. Nesse contexto, tanto os banqueiros como as entidades supervisoras questionam se os custos das operações fora do balanço são tão baixos que compensem os respectivos riscos.

Portanto, a dúvida em relação ao risco de tais operações é uma realidade. Na prática, embora as avançadas técnicas utilizadas na administração de ativos e passivos viabilizem ferramentas para mensurar os riscos de tais operações, o constante surgimento de novos produtos requer indivíduos especialistas no mercado financeiro, com conhecimentos nas áreas de economia, engenharia financeira, contabilidade, administração etc. A ausência de um controle rigoroso das operações com derivativos, por exemplo, pode eventualmente conduzir qualquer instituição financeira a sérias dificuldades.

O fato de não se encontrarem na estrutura do balanço, não quer dizer que sejam transações de pouca relevância. Ao contrário, revela uma limitação no campo da técnica contábil, principalmente no que se refere às fases de identificação e registro simultâneo do evento, bem como dos seus respectivos efeitos subseqüentes.

\subsubsection{O “Conservadorismo" nos Normativos (Prudência)}

$\mathrm{Na}$ atual estrutura de regulamentação do Brasil, relativamente aos normativos emanados pelas autoridades monetárias, verificamos a existência de regras de natureza conservadora, através das quais o Banco Central - na qualidade de organismo supervisor e orientador das instituições financeiras - estabelece procedimentos que buscam manter a solidez do sistema financeiro nacional, de tal forma que ela seja refletida nos demonstrativos contábeis dos bancos e possibilite a confiança dos agentes poupadores da economia. São as seguintes as principais normas prudenciais: limite de endividamento; índice de imobilização; 
limite de diversificação de risco por cliente; limite para as operações de subscrição para revenda e de garantia de subscrição de valores mobiliários de emissão de uma única empresa; limite de aplicação em títulos e valores mobiliários de um mesmo emitente; limite sobre operações compromissadas; limite para constituição da provisão sobre operações de liquidação duvidosa; e, limite mínimo de capitalização dos bancos (Acordo da Basiléia).

O princípio da prudência requer que os ativos e as receitas sejam avaliados pelo menor valor, e os passivos e as despesas sejam evidenciados pelo maior valor, dentre as alternativas possíveis, objetivando retratar prejuízos potencialmente existentes. No Brasil, os prejuízos potencialmente existentes nos balanços dos bancos liquidados pelo Banco Central (Econômico e Bamerindus), não foram devidamente reconhecidos nos seus demonstrativos contábeis (balanço e demonstração de resultado), os quais, conseqüentemente, não retratavam as respectivas situação econômica e financeira. Os ativos e passivos de tais instituições estavam, portanto, super e sub avaliados, respectivamente, distorcendo a análise dos seus demonstrativos e implicando em índices de capitalização confortáveis, comparativamente ao percentual exigido pela Resolução 2099 (Acordo da Basiléia).

Especificamente com relação ao Banco Econômico, a Gazeta Mercantil destacou, no dia 11 de setembro de 1995, em um encarte especial intitulado "O Caso Econômico", os principais pontos que determinaram o fracasso daquela instituição ${ }^{15}$ :

- dez devedores com uma inadimplência de quase US\$ 600 milhões, dos quais US\$ 200 milhões devidos unicamente por uma construtora;

15 Em Apêndice, segue resultado da pesquisa do índice de capitalização de 10 bancos, no qual mostramos os efeitos na capitalização do Banco Econômico, na hipótese em que um montante de ativos duvidosos fossem baixados em contrapartida com o patrimônio líquido daquela instituição, nos trimestres compreendidos no período de dez/94 a jun/95. 
- investimento em empresa de destilaria de álcool, que tempos depois veio a falir;

- crédito junto ao governo de US\$ 300 milhões oriundo do saldo do Fundo de Compensação de Variações Salariais;

- empréstimos a empresas ligadas a diretores;

- elevados índices de imobilização (dez/94=82\%; mar/95=99\%; jun/95=96\%);

- fraudes e golpes praticados pelos próprios funcionários.

Quanto à contabilização dos derivativos, NAKAMURA (1996, p.363) ressalta os problemas existentes nos procedimentos atualmente utilizados: prejudicam o "matching" de receitas e despesas e, por conseguinte, da apuração do lucro; e, falta de sintonia com os efeitos econômico-financeiros das operações. Conclui, apresentando os seguintes critérios, baseados na teoria contábil e aplicáveis aos derivativos, que se efetivados contribuirão, sobremaneira, para um correto controle destas operações:

- Ativo: deve-se considerar como ativo o ganho embutido no contrato de derivativos, ainda não pago, à exceção do contrato a termo;

- Passivo: deve-se considerar como passivo a perda embutida no contrato de derivativo, ainda não paga, à exceção do contrato a termo;

- Valor nocional: não se constitui em ativo ou passivo, à exceção do contrato a termo;

- Contrato a termo: por envolver entrega futura do ativo-objeto e fluxo de caixa do valor principal, deve-se reconhecer o ativo e o exigível integralmente; 
- Avaliação do Ativo e do Exigível em geral (não apenas derivativo): pelo "fair value", isto é, “a importância pela qual um ativo pode ser transacionado ou um passivo liquidado, entre partes conhecedoras do assunto e dispostas, numa transação sem favorecimento ('arm's lenght transaction')";

- Receitas e despesas reconhecidas em resultado à medida que o "fair value" dos instrumentos financeiros fosse alterando-se, sem admitir critérios de diferimentos;

- Reconhecimento de lucro ou prejuízo "all-inclusive";

\subsubsection{A Transparência nos Balanços (Evidenciação)}

A quebra sucessiva de diversos bancos, a partir de dezembro de 1994, gerou uma crescente descrença quanto à confiabilidade dos balanços apresentados pelas instituições financeiras brasileiras. De fato, balanços aparentando uma "sólida" situação econômicofinanceira, simplesmente não retratavam a realidade dos bancos em insolvência. Na prática, as regras de contabilidade existentes para os bancos, não eram observadas a contento, ou mesmo, sendo seguidas, deixavam arestas que permitiam constar no balanço ativos de baixa ou nenhuma liquidez. A Resolução $n^{0}$ 1748, por exemplo, determina que os empréstimos concedidos por um banco e não pagos até 60 dias depois de vencidos devem ser lançados como despesa, pelo menos em parte. Ocorre, porém, casos de operações de crédito em atraso - estando o devedor reconhecidamente incapacitado de pagar suas obrigações (falido) -, são mantidas como "ativos" no balanço do banco, até ultrapassar o prazo de 60 dias permitido pelo BACEN, gerando inclusive "receitas efetivas" integralmente. Em tais casos, o correto seria baixar tais ativos imediatamente como prejuízos, independentemente do crédito estar vencido ou vincendo. Com este procedimento, o balanço evidenciaria a real situação das operações de crédito da instituição credora. 
Há casos, também, das operações de crédito em atraso renegociadas, que deixam de figurar como "operações em atraso", mas que na maioria dos casos, não representam ativos de boa liquidez, ou seja, não geram fluxos de caixa favoráveis à instituição financeira. Nestes caso, é imprescindível uma ressalva pelos auditores, evidenciando o montante da receita gerada pelo ativo, sem a correspondente entrada de recursos financeiros para o banco.

BYDALEK sugere a adoção de oito medidas, necessárias para proporcionar maior transparência às demonstrações financeiras dos bancos:

1. O balanço consolidado do banco comercial, banco de investimentos, financeira, companhia de leasing, companhia de crédito imobiliário, corretora de títulos e valores mobiliários, filiais e subsidiárias internacionais, como é fornecido do Banco Central, deve ser divulgado trimestralmente para o mercado. As subsidiárias do banco no exterior, hoje reportadas apenas por equivalência patrimonial, devem ser consolidadas linha por linha, permitindo uma avaliação das dimensões e qualidade dos Ativos e Passivos;

2. Os auditores devem ser os mesmos para todo o conglomerado financeiro, inclusive nas filiais e subsidiárias internacionais e mesmo nas atividades nãobancárias, se houver;

3. Todos os bancos detêm investimentos de conversão imediata em dinheiro, e devem ter condições de convertê-los em dinheiro a qualquer momento. Nas notas explicativas o banco deve especificar a qualidade desses títulos:

3.1 Liquidez dos títulos: especificar os títulos de liquidez imediata e os que estão em garantia, como aqueles mantidos no Banco Central como reservas compulsórias; 
3.2 Origem dos títulos: público (distinguindo entre Federal, Estadual e Municipal) e privado (distinguindo entre liquidez imediata e pouco ou nenhuma liquidez por falta de mercado disponível para negociação);

3.3 Tipo de moeda do título: real ou moeda estrangeira;

3.4 Prazos de vencimento dos títulos: até 90 dias; de 91 a 180 dias; de 181 a 360 dias; mais de 360 dias;

4. Os bancos devem mostrar, sem mencionar os nomes, o total emprestado aos vinte maiores tomadores e o total de empréstimos feitos ao maior tomador, nas demonstrações trimestrais;

5. A carteira de créditos deve indicar a área de atividade do tomador, não podendo cada categoria (montadoras de caminhão e automóveis, indústria de autopeças, papel e celulose, varejo, serviços financeiros etc) ultrapassar a $10 \%$ do total;

6. Os empréstimos para capital de giro renegociados devem ser divulgados como renegociação nos balancetes trimestrais e nas notas explicativas dos balanços semestrais auditados. Uma grande proporção de créditos renegociados, em comparação com o total das operações de crédito, é um sinal de fragilidade potencial da instituição. $\mathrm{O}$ detalhamento dos empréstimos reestruturados sinalizaria, ao mercado, a qualidade dos ativos de crédito e a qualidade do fluxo de caixa do banco;

7. Todas as operações de crédito deveriam ser registradas, claramente, nos balanços. Ativos e operações de crédito de risco oculto podem minimizar, por vezes, de maneira significativa, o verdadeiro risco de crédito de um banco. Os bancos 
vendem créditos a terceiros, mas continuam a garanti-los. Os ativos de crédito diminuem, mas o banco continua responsável pelo pagamento. Esses tipos de garantia são extensões de crédito e devem ser visíveis, como ativos de risco;

8. Os recursos transferidos de empresas coligadas, família ou acionistas, ou quaisquer outros ligados ao banco e seus acionistas controladores, devem ser informados abertamente. CDBs comprados por uma indústria de propriedade dos mesmos acionistas que controlam o banco, ou pela subsidiária internacional do banco, ou seus acionistas, merecem ser examinados.

NAKAMURA aponta, também, para a importância da evidenciação das operações com derivativos, sugerindo procedimentos tanto para operações dentro como fora do balanço (1996, p.364):

- "Disclosure on-balance-sheet": Ativos e Passivos avaliados por critério homogêneo e com significado econômico, isto é, "fair value". Lucro (perda) evidenciado de modo "all-inclusive", mas evidenciando a divisão desse lucro (perda) em diferentes recipientes;

- "Disclosure off-balance-sheet":

Controle Contábil dos Contratos de Derivativos - contabilização do valor atual dos contratos em contas de compensação, nos moldes do controle gerencial em "livros", para servir de subsídio às notas explicativas; 


\section{"Disclosure"}

- Publicação de quadros (ou mesmo reagrupamento de contas do Balanço) - apresentando descasamento de posições da empresa como um todo, incluindo instrumento derivativos e não derivativos.

- Evidenciação de descasamento de prazos.

- Evidenciação do "Value-at-risk" (VAR).

- Evidenciação de valores médios anuais para os itens anteriores "offbalance-sheet".

- Evidenciação do risco de crédito dos derivativos.

\section{7. Índice Padrão}

O Comitê tinha, inicialmente, duas opções para determinar o índice padrão que representasse uma razão mínima entre o capital e o ativo ponderado pelo risco. A primeira consistia na escolha de um número baixo, na expectativa de que todos os bancos o observassem de imediato; a segunda, optava pela seleção de um número mais alto a ser atingido dentro de um prazo previamente estipulado. Prevaleceu a segunda opção, adotandose um índice de oito por cento (pelo menos metade do qual composto de capital essencial), condizente, no ponto de vista do comitê, com o objetivo de assegurar, com o passar do tempo, razões sólidas e consistentes de capital para todos os bancos internacionalmente ativos. 
Tal índice, segundo MAGLIANO (1994, p.4), é resultado de estatísticas realizadas a partir de estudos prévios entre os primeiros cinqüenta bancos dos EUA, que indicavam uma relação capital/ativos extremamente próxima. Para COOKE (1994, p.281) - presidente do Comitê da Basiléia - apud HALL, o percentual de oito por cento foi estabelecido "porque havia um grande consenso entre os países membros que o mesmo refletia os níveis de capital à época mantidos pelos bancos mais capitalizados, bem como representava uma meta razoável passível de ser atingida por todos os bancos no curso do período de transição".

No Brasil, a Resolução no 2099 estipulou o mesmo índice estabelecido pelo Acordo da Basiléia: 8\%. Em 25 de junho de 1997, referido índice foi elevado para 10\%, através da Resolução no 2399 do $\mathrm{CMN}$, reduzindo de 12,5 para 10 vezes o nível máximo de alavancagem das instituições financeiras (na hipótese de um portfólio todo composto de operações classificadas como de risco $100 \%$ ). Tal mudança entrou em vigor a partir de $1^{\circ}$ de agosto de 1997, tendo o mercado até 31/12/97 para eliminar eventuais faltas de enquadramentos, decorrentes da aplicação daquele normativo. Nova modificação foi efetuada em 27 de novembro de 1997, ocasião em que o Banco Central do Brasil, através da Circular $n^{\circ} 2784$, aumentou o índice para 11\%, dando um prazo até dezembro de 1998 para os bancos se ajustarem ao novo parâmetro.

\subsection{A Incorporação do Risco de Mercado ao Acordo da Basiléia - Metodologias de Mensuração}

A proposta inicial do Comitê da Basiléia não previa em seu conteúdo a exigência de aporte de capital para cobrir os riscos de mercado incidentes sobre as operações com derivativos. Contudo, o desenvolvimento do mercado de derivativos exigiu uma administração de risco mais apurada, tanto por parte dos órgãos supervisores como pelas 
instituições financeiras. Os riscos inerentes a tais operações, dependendo do seu volume e do porte do banco, demonstraram que podem comprometer a sua solidez, como nos casos dos Bancos Barings, Procter \& Gamble, Bankers Trust, Gibson Greetings etc.

O Comitê da Basiléia emitiu em janeiro de 1997, após ter submetido, no período de abril de 1993 a julho de 1998, para consulta, coleta de sugestões e aprovação dos diretores dos bancos centrais do Grupo dos Dez, um suplemento especial ${ }^{16}$ à proposta original de julho de 1988, no qual foi elaborada uma estrutura para aplicar encargos de capital ("Tier 3") aos riscos de mercado incorridos pelos bancos, com início previsto para janeiro de 1998.

Conforme comentamos no capítulo 2, o Comitê da Basiléia propôs a adoção pelos Bancos de uma das seguintes metodologias, que têm como objetivo quantificar os riscos inerentes às operações com derivativos e assim proporcionar um aporte adequado de capital pelas instituições financeiras: Metodologia Padronizada (Standard) e Metodologia baseada no Modelo Interno de Gestão de Risco.

Neste segmento descreveremos um resumo das metodologias de incorporação do risco de mercado ao Acordo da Basiléia.

\section{METODOLOGIA PADRONIZADA}

Esta metodologia introduz encargos de capital específicos a serem aplicados nas seguintes situações: ao valor corrente de mercado de posições em aberto (incluindo-se posições de derivativos) em títulos de dívida e valores mobiliários, na contabilidade dos bancos; e as posições globais em moedas dos bancos com relação ao risco cambial. 
As propostas para os títulos de dívidas e valores mobiliários são baseadas no método de segregação, que diferencia as exigências para riscos específicos - isto é, o risco de prejuízo causado por oscilações adversas de preços de um título, devido, principalmente, a fatores relacionados ao emitente deste título - das de risco geral de mercado - isto é, o risco de prejuízo que surge de mudanças adversas nos preços de mercado.

Convém ressaltar duas importantes exigências introduzidas na sistemática de avaliação padronizada: nas negociações com commodities, particularmente derivativos, os bancos deverão avaliar os riscos e aplicar o respectivo aporte de capital; no tratamento das opções, as várias alternativas diferentes serão permitidas, de acordo com os critérios estabelecidos pelas autoridades reguladoras.

\section{METODOLOGIA DE MODELOS INTERNOS}

O Comitê da Basiléia verificou que os bancos já possuíam modelos de gerenciamento capazes de calcular o valor da exposição global ao risco de mercado, os quais eram expressos em termos de "Value-at-Risk (VAR)". Segundo NAKAMURA, "value-at-risk" significa: "valor provável de perda que pode ser gerada pela instituição, em face das oscilações desfavoráveis de preços e taxas de juros ocorridas no mercado, com um certo grau de confiança estatística" (1996, p.298).

$\mathrm{Na}$ opção pelo uso de modelo interno, a instituição deverá seguir as seguintes orientações gerais emanadas pela autoridade reguladora: manutenção de provas que o sistema de risco do banco é consistente e está implementado com integridade; possuir um

${ }^{16}$ No Suplemento Especial também consta uma nova metodologia para tratamento do risco de crédito associados a certos itens não incluídos no balanço. 
número suficiente de profissionais preparados para usar modelos sofisticados não somente na área de operações, mas também na área de controle de risco, auditoria e, se necessário, nas de back office; ter modelos que permitam a previsão de perdas com uma exatidão razoável, assim como o histórico dessas previsões; conduzir teste-limite de esforço de acordo com o que estiver estabelecido no parágrafo seguinte.

Além das exigências acima, as instituições financeiras, que utilizarem modelos internos para avaliar seu capital, deverão observar os seguintes aspectos:

\section{A - Padrões Qualitativos}

Os banco centrais especificarão o número de critérios qualitativos que as instituições financeiras deverão seguir, antes que elas tenham a autorização para aplicar os modelos internos. O grau de observância pelos bancos de todos os critérios exigidos pela autoridade reguladora implicará na aplicação maior ou menor do fator de multiplicação para exigência de capital, na forma prevista na letra B seguinte. Seguem-se, abaixo, os critérios qualitativos:

a) o banco deve ter uma unidade de controle de risco independente que seja responsável pelo desenho e implementação do sistema de gestão de risco. A unidade deve produzir e analisar relatórios diários sobre o resultado do modelo de avaliação de risco do banco, incluindo uma avaliação da relação entre as avaliações de exposição de risco e limites de negociação. Essa unidade deve ser independente das unidades de negociação e deve reportar-se diretamente ao executivo principal da instituição;

b) a unidade deve conduzir um programa de testes a posteriori regular, isto é, uma comparação ex-post da medida de risco gerada pelo modelo contra mudanças 
diárias efetivas no valor da carteira durante longos períodos de tempo, bem como mudanças hipotéticas baseadas em posições estáticas;

c) o executivo principal da instituição deve manter-se sempre envolvido com o processo de controle de risco e reconhecê-lo como um aspecto fundamental para uma correta gestão dos seus negócios, destinando os recursos que se fizerem necessários para sua consecução. Adicionalmente, os relatórios diários preparados pela unidade de controle de risco devem ser revisados por uma autoridade hierarquicamente superior, com experiência suficiente para determinar reduções de posições tomadas por operadores individualmente e reduções na exposição de risco global do banco;

d) o modelo de mensuração do risco interno do banco deve estar integrado no processo de gestão de risco da instituição. Os resultados devem integrar o processo de planejamento, monitoração e controle do perfil do risco de mercado da instituição financeira;

e) o sistema de gestão de risco deve ser utilizado em conjunto com os limites internos de operações e exposição. Os limites operacionais devem estar relacionados com o modelo de risco do banco de modo consistente no tempo e de modo bem compreendido por operadores e pelo seu principal gestor;

f) deve se implantada uma rotina e um programa de testes-limite, para um suplemento da análise de risco baseada no resultado diário do modelo de avaliação de risco do banco. Os resultados de tais testes deverão ser revisados periodicamente pelo gestor principal do banco e devem ser refletidos nas políticas e limites estabelecidos pela gerência e pelo conselho de administração. Nos casos 
em que os testes-limite revelarem uma vulnerabilidade particular em determinadas situações específicas, medidas corretivas deverão ser tomadas imediatamente para anular tais riscos (por exemplo, realizando o hedge contra tal resultado ou reduzindo a exposição do banco);

g) os bancos devem ter rotinas que garantam o cumprimento de acordo com as políticas internas, controles e procedimentos com relação à operação de sistema de avaliação de risco. Por exemplo, o banco deve manter um manual de gestão de risco que descreva os princípios básicos do sistema de gestão de risco e forneça um detalhamento das técnicas empíricas utilizadas para se avaliar o risco de mercado;

h) deve ser realizada, pela auditoria interna do banco, uma revisão periódica - não menos do que uma vez por ano - do sistema de gestão de risco, com foco tanto sobre as atividades que efetivamente executam as tarefas de controle, quanto aquelas indiretamente vinculadas, devendo ser verificado, no mínimo:

- a adequação da documentação do sistema de gestão de risco e do processo;

- a organização da unidade de controle de risco;

- a integração das avaliações de risco de mercado na gestão de risco diária;

- o processo de aprovação para modelos de precificação de risco e sistema de avaliação utilizados por pessoal operacional e administrativo;

- a validação de qualquer mudança significante durante o processo de avaliação de risco; 
- a abrangência dos riscos de mercado captados pelo modelo de avaliação de risco;

- a integridade do sistema de informação gerencial;

- a exatidão e totalidade dos dados das posições;

- a verificação da consistência, oportunidade e confiabilidade das fontes de informações usadas para rodar os modelos internos, incluindo a independência dessas fontes de informação;

- a exatidão e adequação das hipóteses de volatilidade e correlação;

- a exatidão dos cálculos de transformação e valorização do risco;

- a verificação da exatidão do modelo através de testes a posteriori freqüentes como descrito na alínea "b" acima.

\section{B - Especificação dos Fatores de Risco de Mercado}

Os fatores de risco de mercado devem ser suficientemente adequados para capturar todos os riscos materiais inerentes à carteira, com relação às posições em negociação de itens constantes ou não do balanço. Segundo o Comitê, as seguintes orientações devem ser seguidas:

- para as taxas de juro, deve haver um conjunto de fatores de risco que corresponda às taxas de juro em cada moeda na qual o banco tenha posições, incluídas ou não no balanço; 
- para taxas de câmbio, o sistema de avaliação de risco deve levar em consideração os fatores de risco correspondentes a cada uma das moedas estrangeiras nas quais o banco tomou posição. Deverá haver fatores de risco que correspondam a taxa de câmbio entre a moeda doméstica e cada uma das moedas estrangeiras, na qual o banco possua uma exposição significativa;

- para os preços de ações e de índices de ações, deverá haver fatores de risco correspondentes a cada um dos mercados referenciados em valores mobiliários, no qual o banco detém fatores significantes. Por exemplo: fator que seja elaborado para captar as amplas oscilações de mercado das ações; fatores de risco correspondentes a vários setores do mercado de ações globais; fatores de risco correspondentes às volatilidades das emissões de ações;

- para os preços de commodities deve haver fatores de risco correspondentes a cada um dos mercados referenciados em commodities, no qual o banco detenha posições significativas.

\section{C - Padrões Quantitativos}

Especificados os fatores de risco de mercado, conforme descrito na letra "B" acima, calcula-se diariamente o "Value-at-Risk"(VAR), usando o $99^{\circ}$ percentil, intervalo de confiança de uma ponta, em um prazo mínimo de dez dias úteis. O período de observação histórico está sujeito à duração mínima de um ano. Os bancos devem reconhecer as correlações empíricas contidas dentro das amplas categorias de risco, mas o valor de risco abrangendo estas categorias deve ser agregado, baseado em somatório simples. Os modelos também devem captar com precisão os riscos peculiares associados às opções. O encargo de capital será o maior dos seguintes valores: 
- valor de risco do dia anterior;

- uma média do valor de risco diário sobre cada um dos 60 dias úteis anteriores, multiplicado por um fator avaliado pela autoridade supervisora, baseado em sua avaliação da qualidade do sistema de gestão de risco de cada banco, sujeita a um mínimo absoluto de três. Deve-se somar a este fator um elemento a mais que estará diretamente relacionado à performance posterior do modelo.

O cálculo do value-at-risk já vinha sendo uma metodologia bastante utilizada pelo mercado financeiro internacional, tanto para a administração dos recursos dos próprios bancos quanto os de terceiros. Os principais pontos que contribuíram para a sua aceitação foram: ser conhecida internacionalmente; ter boa fundamentação estatística; e, existência de modelos informatizados.

Foi J.P. MORGAN quem desenvolveu uma metodologia, denominada Risk Metrics para calcular o VAR, utilizando-se da aplicação direta da teoria do portfólio de Markowitz. A modelagem informa uma visão global, fornecendo um número que expressa o risco global da instituição, obtido através das correlações e das volatilidades dos instrumentos financeiros.

Como alternativa a este método para o cálculo do VAR existe a Simulação Histórica e a de Monte Carlo. A primeira utiliza os retornos reais históricos para traçar os cenários para o cálculo do risco; na segunda, os cenários são traçados de forma probabilística, de acordo com a família paramétrica previamente selecionada como representativa das variações dos fatores de mercado. 


\section{Segundo GONÇALVES:}

O VAR é calculado com base na distribuição das mudanças de preços ocorridas em um dado período histórico de observação. Um VAR de R\$ 1 milhão significa que a carteira em questão com 95\% de probabilidade, perderá um milhão no intervalo de 24 horas. Tal número permite aos agentes fixar as perdas máximas esperadas compativeis com a sua alocação de capital e aversão ao risco (1997, p.5).

No Brasil, grande parte dos gerentes financeiros, responsáveis pelo controle do risco sobre os instrumentos financeiros, se utilizam dos modelos oriundos do exterior, porém adaptando-os à realidade brasileira. Outros, porém, preferem criar os seus próprios modelos, de acordo com as especificidades da instituição financeira em que atua e o mercado em que está inserido.

Apresentamos, abaixo, duas das fórmulas necessárias para o cálculo do VAR (as fórmulas variam de acordo com os dias e números de títulos analisados), citadas por SILVA e RABBAT, no artigo Valor em risco e margem de garantia de portfólios de derivativos:

Valor em risco diário para cada ativo no dia $t$ :

$\mathrm{VAR}_{i, t}=\mathrm{VM}_{i, t} \times 2,33 \times \mathrm{DP}_{i, t}, \mathrm{i}=1 \ldots . .5$

Onde $\mathrm{VM}_{i, t}=$ valor de mercado do ativo $i$ no dia $t$;

$\mathrm{DP}_{i, t}=$ desvio padrão do retorno do ativo $i$ no dia $t$. 
O número 2,33 significa que o valor em risco cobre $99 \%$ dos movimentos adversos de preços esperados.

\section{Valor em risco diário para o dia $t$ para o portfólio como um todo:}

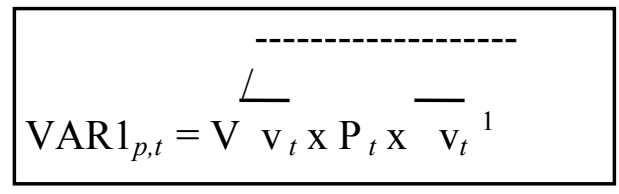

$\overline{\mathrm{v}_{t}}=$ vetor dos VAR1 individuais no dia $t$;

$\mathrm{P}_{t}=$ matriz de correlação dos retornos no dia $t$,

$\overline{\mathrm{v}^{1}}=$ vetor transposto dos VAR1 individuais.

\section{D - Validação}

Os modelos internos dos bancos devem ser validados por auditores externos e/ou pela autoridade reguladora, que tomarão, pelo menos, as seguintes medidas:

a) verificar se os processos de validade interna estão operando de forma satisfatória;

b) garantir que as fórmulas usadas no processo de cálculo e as precificações sejam confirmadas por unidade qualificada;

c) verificar se a estrutura dos modelos internos é adequada, relativamente às atividades do banco e à sua cobertura geográfica;

d) verificar os resultados dos testes a posteriori para garantir que o modelo forneça uma medida confiável de perdas potenciais com o tempo;

e) assegurar que os fluxos de informações e processos associados ao sistema de avaliação de risco sejam transparentes e acessíveis. 


\section{E - A Combinação dos Modelos Internos e a Metodologia Padronizada}

Os bancos que começarem a utilizar os modelos em uma ou mais categorias de fator de risco deverão, com o passar do tempo, estender seus modelos para todos os seus riscos de mercado. Um banco que tenha desenvolvido um ou mais modelos não mais poderá voltar a avaliar um risco, utilizando a metodologia padronizada uma vez que já o tenha calculado através de modelos.

\subsection{Quadro-Resumo das deficiências apresentadas no Acordo da Basiléia}

Maxilimilian J. B. Hall (1994, p.270), quando escreveu o estudo intitulado The Measurement and Assessment of Capital Adequacy for Banks: A Critique of the G-10 Agreement, apresentou um quadro-resumo - o qual transcrevemos abaixo - em que destaca as principais deficiências verificadas na abordagem baseada no risco para avaliar a adequação de capital, bem como sugeriu uma gama de alternativas que pudessem aperfeiçoar o citado acordo. 


\begin{tabular}{|c|c|}
\hline \multicolumn{2}{|c|}{$\begin{array}{l}\text { Quadro } 1 \\
\text { Uma Avaliação do Acordo do G-10: Deficiências e Alternativas para } \\
\text { Reformas }\end{array}$} \\
\hline Deficiências & Sugestões \\
\hline $\begin{array}{l}\text { O acordo não é legalmente compulsório, o que prejudica a } \\
\text { sua eficácia. }\end{array}$ & Incorporar o acordo dentro da estrutura legal. \\
\hline $\begin{array}{l}\text { A cobertura geográfica é limitada, desfavorecendo a } \\
\text { estabilidade do sistema bancário internacional. }\end{array}$ & $\begin{array}{l}\text { Ampliar a cobertura através da divulgação de benefícios } \\
\text { mais amplos e/ou promoção de debates em outros fóruns. }\end{array}$ \\
\hline $\begin{array}{l}\text { A metodologia é defeituosa uma vez que adota avaliações } \\
\text { de risco inadequadas. }\end{array}$ & Mudar a estrutura de avaliação de riscos. \\
\hline As convenções utilizadas e os pesos de riscos são inexatos. & $\begin{array}{l}\text { Rever os cálculos com mais freqüência de forma que reflitam } \\
\text { análises atualizadas. } \\
\text { Incorporar riscos adicionais dentro das medidas de risco. } \\
\text { Mudar a base de medição do risco. }\end{array}$ \\
\hline $\begin{array}{l}\text { A metodologia induz à incorreta alocação de capital dentro } \\
\text { da indústria bancária. }\end{array}$ & $\begin{array}{l}\text { Mudar a base de avaliação do risco. } \\
\text { Realçar a importância de outros fatores quando da alocação } \\
\text { do capital nos bancos. }\end{array}$ \\
\hline $\begin{array}{l}\text { A metodologia induz à incorreta alocação de capital entre o } \\
\text { setor bancário e não bancário. }\end{array}$ & $\begin{array}{l}\text { Mudar as bases de avaliação de risco e as exigências globais } \\
\text { de capital. }\end{array}$ \\
\hline $\begin{array}{l}\text { A metodologia induz a distorções no "pricing" dos bancos } \\
\text { e em outras decisões de negócios. }\end{array}$ & $\begin{array}{l}\text { Mudar as bases de avaliação de risco. } \\
\text { Ressaltar nos bancos a importância de considerar outros } \\
\text { fatores antes de se tomar qualquer decisão. }\end{array}$ \\
\hline $\begin{array}{l}\text { A metodologia induz à incorreta alocação de recursos } \\
\text { devido a uma restruturação "induzida" do balanço dos } \\
\text { bancos. }\end{array}$ & $\begin{array}{l}\text { Mudar as bases de avaliação de risco. } \\
\text { Rever os cálculos dos pesos de risco e fatores de conversão. }\end{array}$ \\
\hline $\begin{array}{l}\text { O Acordo pode gerar uma falsa idéia de solidez - a estrita } \\
\text { aderência ao Acordo por todos os bancos } \\
\text { internacionalmente ativos não assegura a solvência e } \\
\text { conseqüentemente a estabilidade do sistema financeiro. }\end{array}$ & $\begin{array}{l}\text { Ressaltar nos bancos e nos seus supervisores as limitações do } \\
\text { Acordo como um dispositivo para assegurar a solvência dos } \\
\text { bancos individualmente. A importância de medidas } \\
\text { complementares deveria ser enfatizada. }\end{array}$ \\
\hline $\begin{array}{l}\mathrm{O} \text { acordo não assegura } \mathrm{o} \text { objetivo de neutralidade } \\
\text { competitiva. }\end{array}$ & $\begin{array}{l}\text { Reduzir o âmbito da prudência. } \\
\text { Ampliar a cobertura geográfica. } \\
\text { Fazer alguma concessão para "redes" nas atividades fora do } \\
\text { balanço. }\end{array}$ \\
\hline $\begin{array}{l}\text { O Acordo pode ter contribuído para o desenvolvimento de } \\
\text { uma crise mundial de crédito. }\end{array}$ & $\begin{array}{l}\text { Levar em conta uma folga se o papel de colaboração puder } \\
\text { ser comprovado. }\end{array}$ \\
\hline $\begin{array}{l}\text { O Acordo pode induzir os bancos a aumentarem o risco do } \\
\text { portfólio, com a possibilidade de elevar o risco de } \\
\text { insolvência. }\end{array}$ & Mudar as bases de avaliação de risco. \\
\hline
\end{tabular}

Fonte: M.B.Hall, “Towards Better Banking Regulation and Supervision”,Geneva, 1992. 


\section{CAPítulo V}

\section{CONCLUSÕES E RECOMENDAÇÕES}

Nesta etapa conclusiva, procuramos destacar os aspectos mais relevantes tratados no desenvolvimento da pesquisa, fazendo um "link" com os recentes acontecimentos relacionados com as instituições financeiras. Tratamos, também, das vantagens e das deficiências apresentadas no Acordo da Basiléia, na experiência brasileira, bem como dos progressos que ainda podem ser feitos no que se refere à adequação de capital em bancos.

Verificamos que a tendência de redução do número de instituições financeiras não só no Brasil, mas a nível mundial, não teve somente como fator indutor o aumento das exigências de capital determinado pelo Acordo da Basiléia. Diversos fatores conjunturais contribuíram para tal ocorrência. Podemos destacar, dentre outros, os seguintes:

- queda acentuada dos ganhos inflacionários;

- o aumento da competitividade no setor financeiro;

- surgimento de novos instrumentos financeiros; e,

- desregulamentação da economia.

Após implementados todos os ajustes necessários à adaptação a um novo cenário, o capital das instituições financeiras tenderá a ficar mais fortalecido, não só pela exigência prevista no Acordo da Basiléia, mas também, pelo processo de fusão dos bancos, que tende a eliminar do mercado financeiro os créditos de difícil liquidação e compor a carteira de ativos dos bancos com operações "sadias", com maior probabilidade de retorno, suficientes para garantir a solidez do sistema. 
Em conseqüência, a redução do risco no portfólio dos bancos tende a diminuir, devido ao controle mais eficiente das autoridades supervisoras, às políticas conservadoras de concessão de crédito, da exigência de capitalização dos bancos e da necessidade de manutenção de profissionais mais qualificados, especialistas na aferição dos riscos envolvidos nos negócios.

Embora a exigência de adequação do capital no sistema bancário, na forma estabelecida pelo Acordo da Basiléia, contribua para uma maior capitalização das instituições financeiras, isto, por si só, não pode evitar possíveis problemas de solvência, dada a existência de outros fatores que devem ser analisados em conjunto com este indicador, tais como, qualidade dos ativos, rentabilidade, eficiência gerencial e liquidez.

Nas instituições financeiras liquidadas após a implementação do Plano Real, o índice de capitalização evidenciava, no período de dezembro/94 a junho/95, um percentual nunca inferior a $8 \%$, o que demonstra ser ineficaz uma análise isolada de tal indicador.

Tal deficiência, é resultado, também, das práticas de registros contábeis ainda deficientes, que não retratam os eventos que impactam o patrimônio das instituições financeiras de forma adequada e evidenciem a correta situação da empresa. As despesas com provisionamento sobre os créditos em atraso, por exemplo, são registradas com base nas regras estabelecidas pelo fisco, observando-se o limite aceito como dedução para o imposto de renda. Fica evidenciado o conflito entre a essência e a forma por ocasião do registro contábil, prevalecendo, em muitos casos, a opção pela forma, o que prejudica, sem dúvida, a transparência da real situação econômica do banco. Uma solução para este problema seria a observância de uma única legislação, que contemplasse os preceitos de avaliação econômica do patrimônio dos bancos, evidenciando, de uma forma mais realista possível o resultado 
econômico das instituições financeiras, eliminando desse modo a alternativa pela utilização de um demonstrativo enganoso, somente para atender a legislação tributária.

O surgimento de novos produtos financeiros tem sido um desafio adicional para aqueles que analisam e divulgam os efeitos de tais inovações sobre o patrimônio dos bancos. A aceitação pelo Acordo da Basiléia dos modelos de gestão de risco interno dos bancos representou um avanço na busca de mecanismos que possibilitem verificar o real impacto desses instrumentos sobre a riqueza dos bancos.

Os modelos internos, já utilizados pelos grandes bancos internacionais, representam metodologias capazes de calcular o valor da exposição global ao risco de mercado, expressos em termos de "Value-at-Risk". Novas técnicas estão sendo criadas, com o objetivo de incluir no "Value-at-Risk" a exposição dos bancos também aos riscos de crédito. Portanto, ficam abertos novos campos de pesquisa para os estudiosos das ciências vinculadas diretamente à gestão das empresas (administração, contabilidade, economia, estatística etc), na busca de soluções que vençam o desafio que está sendo imposto pelo mercado financeiro.

O pequeno número de categorias de risco $(0 \%, 20 \%, 50 \%$ e $100 \%)$ implica em um enquadramento de ativos de naturezas distintas em determinado grupo, e provoca uma avaliação incorreta da necessidade de capitalização da instituição financeira. Esta avaliação induzirá o mercado a tomar decisões distorcidas em relação ao banco analisado.

A obrigatoriedade de manter os ativos dentro de determinadas categorias, pode acarretar a formação de portfólios incompatíveis com as exigências que a demanda requer, diante de um cenário de crescimento econômico, onde a necessidade de investimentos na expansão do parque industrial, do comércio, dos serviços e da infra-estrutura, exigem um 
volume elevado de recursos em operações de crédito, consideradas na categoria de risco com ponderação de 100\%. Para possibilitar a correspondente alavancagem dos ativos será necessário reforçar o capital das instituições de fomento.

A necessidade de manter o percentual de capital mais elevado, relativamente às operações de crédito, pode induzir, em termos globais a uma crise mundial de crédito, ou, forçar o surgimento de outras alternativas de financiamento, via entidades não-bancárias. 


\section{APÊNDICE \\ ÍNDICE DE CAPITALIZAÇÃO \\ EVOLUÇÃO TRIMESTRAL \\ PERÍODO: DEZEMBRO/94 A DEZEMBRO/96}

Neste tópico, apresentamos através de gráficos a evolução trimestral do índice de capitalização (k) dos seguintes bancos: Banco do Brasil, Econômico, Banco do Nordeste, Bamerindus, Itaú, Bradesco, Nacional, Real, Safra e Meridional. O período observado teve como início o balanço de 31 de dezembro de 1994, data da entrada em vigor da Resolução no 2099 do Conselho Monetário Nacional, e como término o balanço de 31 de dezembro de 1996.

Foram selecionados os balancetes/balanços correspondentes aos trimestres compreendidos entre os meses de dezembro/94 a dezembro/96 (ambos, inclusive), perfazendo um total de oitenta e nove demonstrativos ${ }^{17}$. Os dados foram inseridos em uma planilha eletrônica (Excel 7), sendo utilizados para o cálculo de percentuais, índices, fatores de ponderação e gráficos. Para viabilizar uma análise comparativa, construímos, também, uma tabela matricial (Tabela 1), onde constam os dez bancos selecionados, os trimestres pesquisados e os respectivos índices de capitalização resultantes.

17 O balancete de dezembro de 1996 do Banco Nacional, até a data da última pesquisa no Sisbacen, ainda não tinha sido validado pelo BACEN. 


\section{Banco do Brasil}

\section{PERCENTUAL I DEMONSTRATIVO DA EVOLUÇÃO DO FATOR "k"}

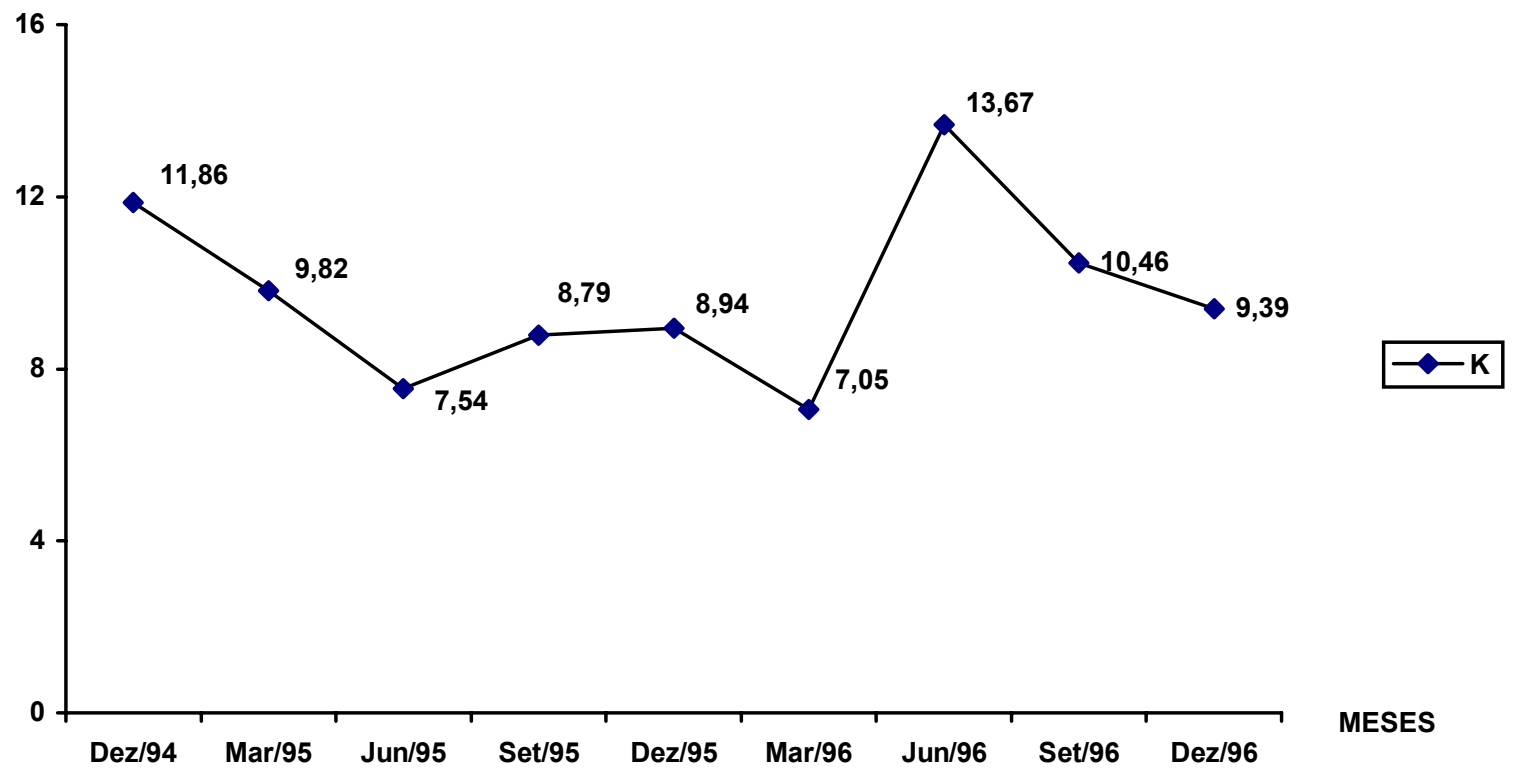

2. Econômico ${ }^{18}$

PERCENTUAL DEMONSTRATIVO DA EVOLUÇÃO DO FATOR "k"

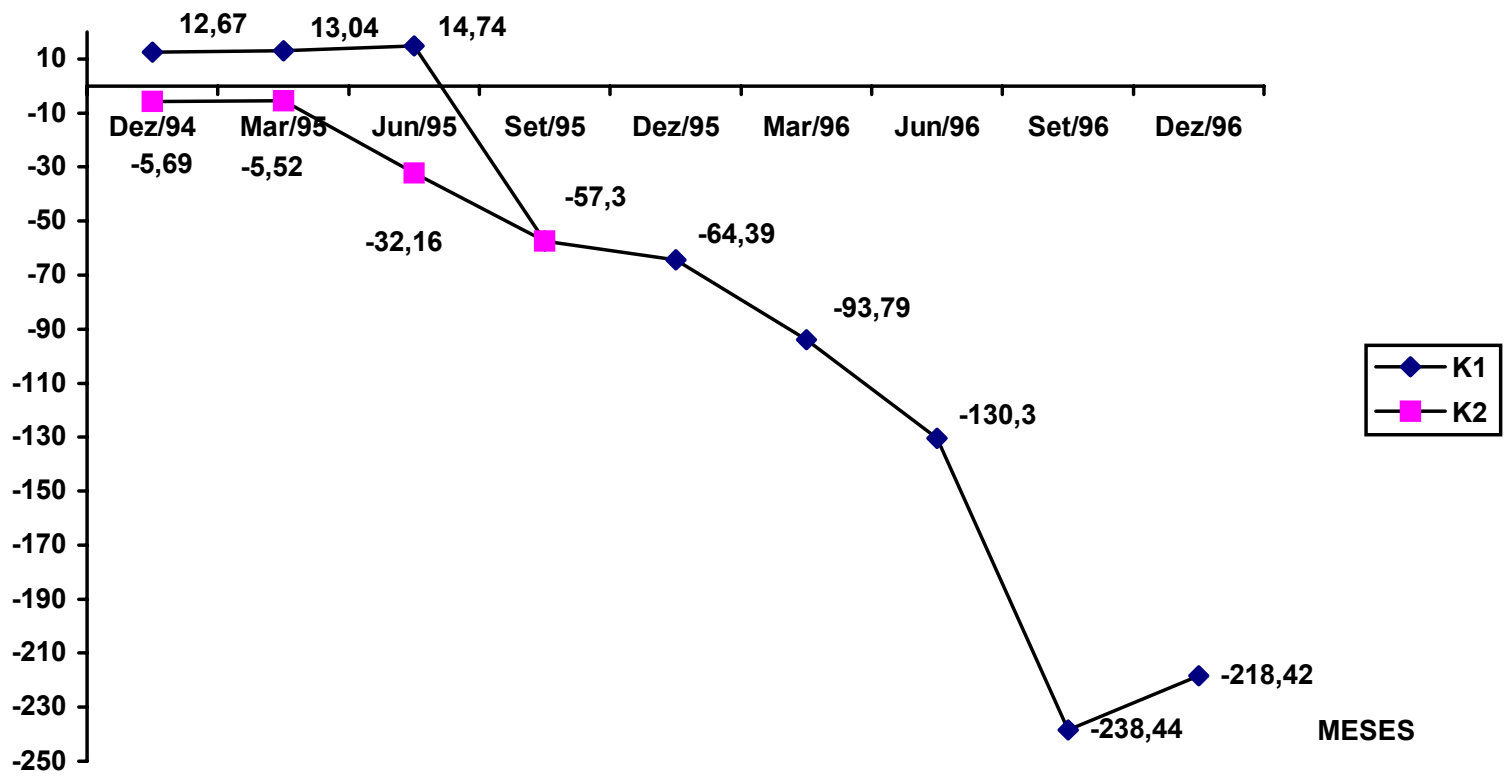

18 K1 = Índice de capitalização até jun/95 com base nos balancetes divulgados pelo Banco Econômico; K2 = índice de capitalização, considerando a baixa do ativo de US\$ 900 milhões/R $\$ 900$ milhões - supondo paridade US\$1,00=R $\$ 1,00$-, nos trimestres de dez/94 e mar/95;e, R\$1,8 bilhão, em jun/95. 


\section{Banco do Nordeste}

\section{PERCENTUAL DEMONSTRATIVO DA EVOLUÇÃo dO FATOR "k"}

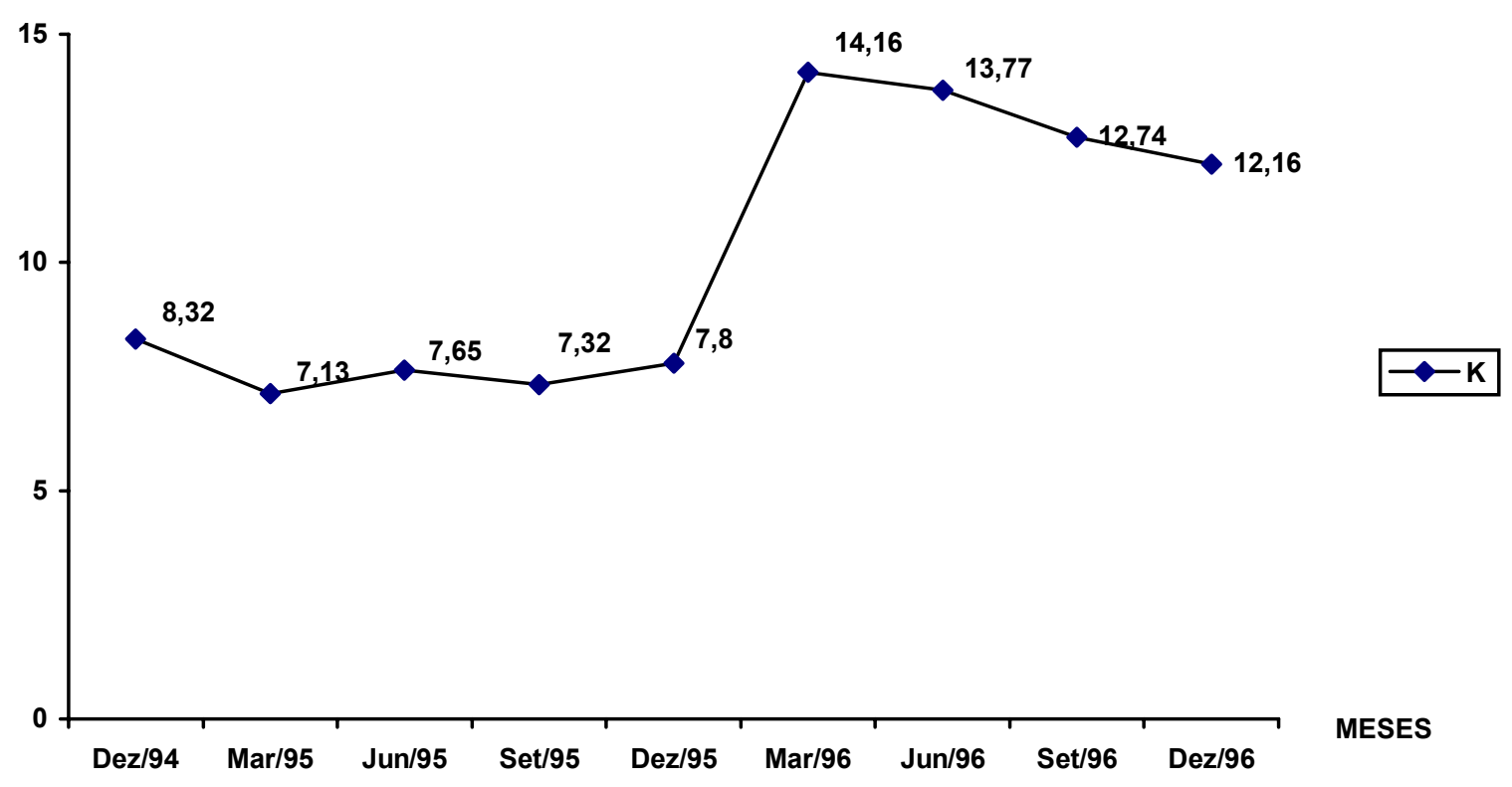

4. Bamerindus ${ }^{19}$

PERCENTUAL DEMONSTRATIVO dA EVOLUÇÃo dO FATOR "k"

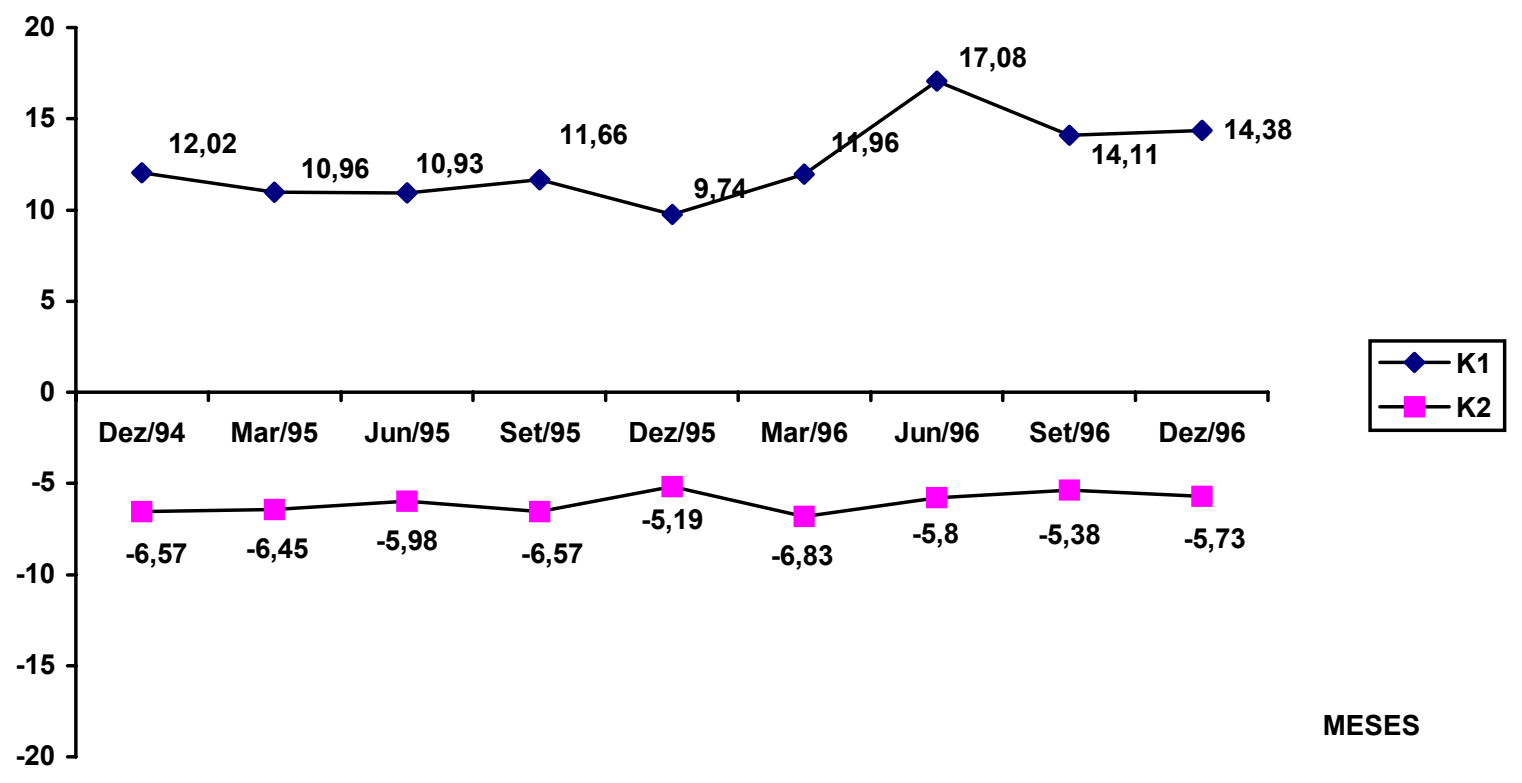

19 K1 = Índice de capitalização até dez/96 com base nos balancetes divulgados pelo Bamerindus; K2 = índice de capitalização, simulado, considerando baixados ativo: 50\% dos Empréstimos; 25\% dos Financiamentos, inclusive imobiliários e rurais. 


\section{Itaú}

PERCENTUAL DEMONSTRATIVO DA EVOLUÇÃO DO FATOR "k"

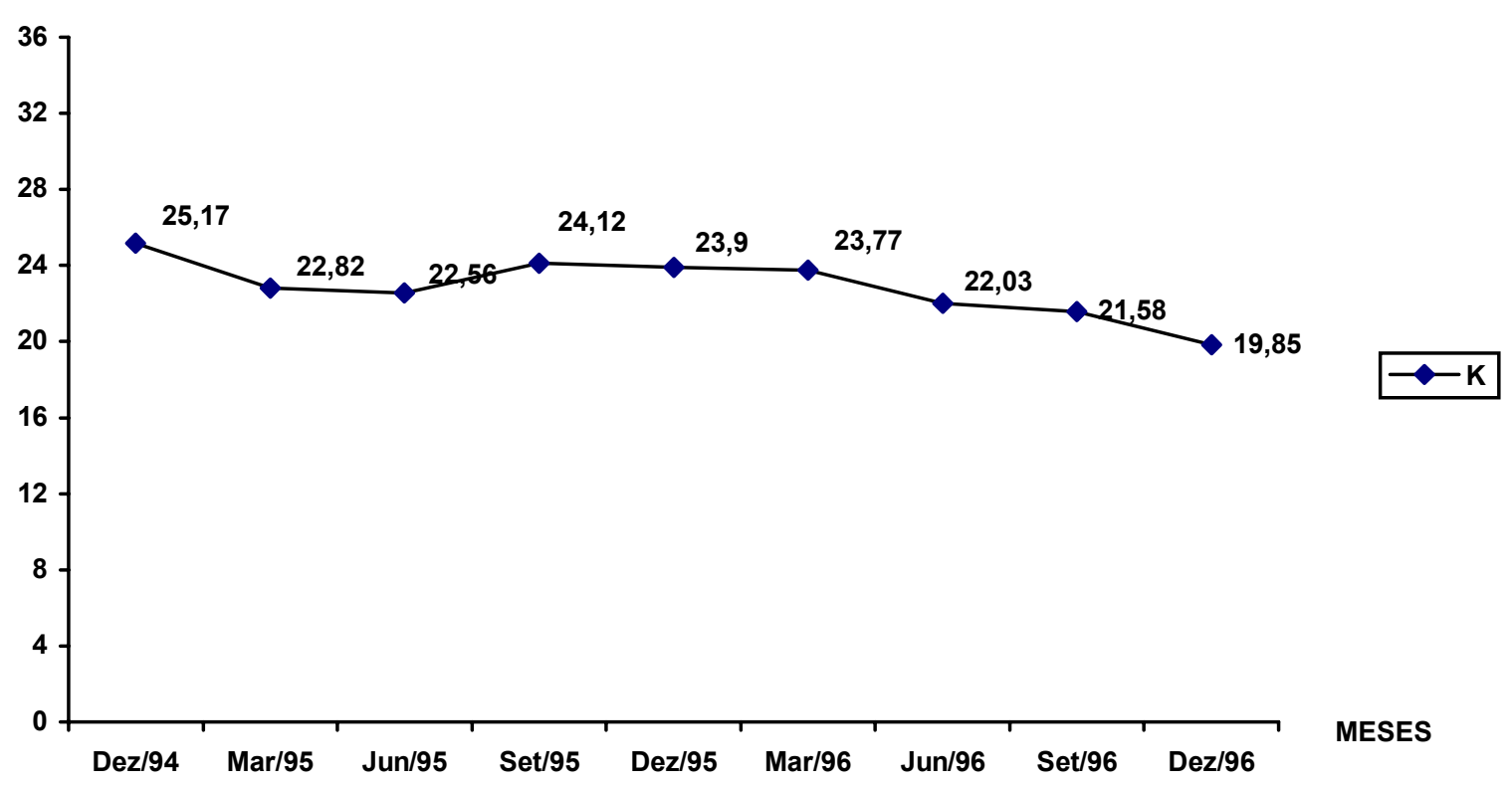

6. Bradesco

PERCENTUAL DEMONSTRATIVO DA EVOLUÇÃO dO FATOR "k"

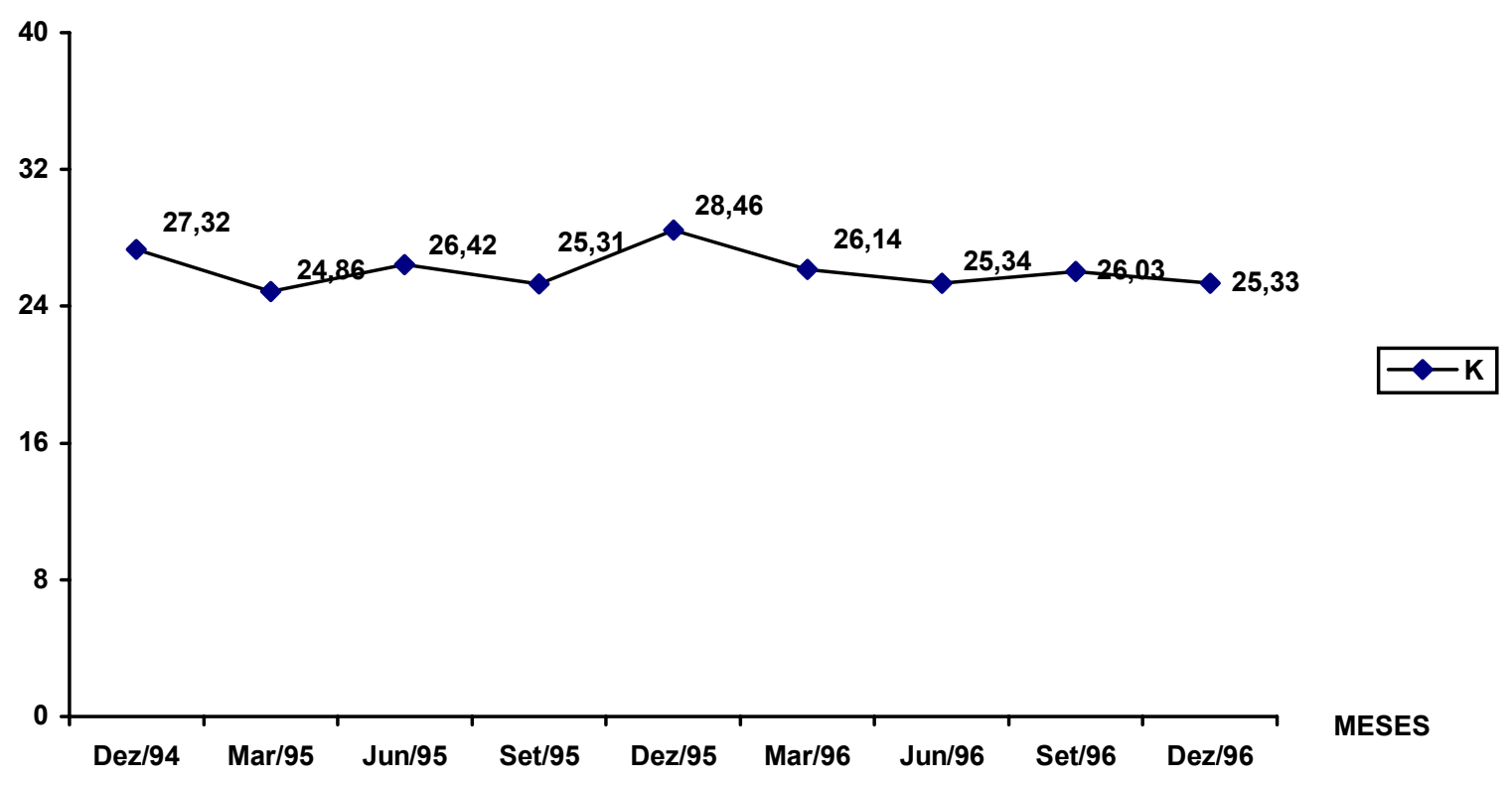


7. Nacional $^{20}$

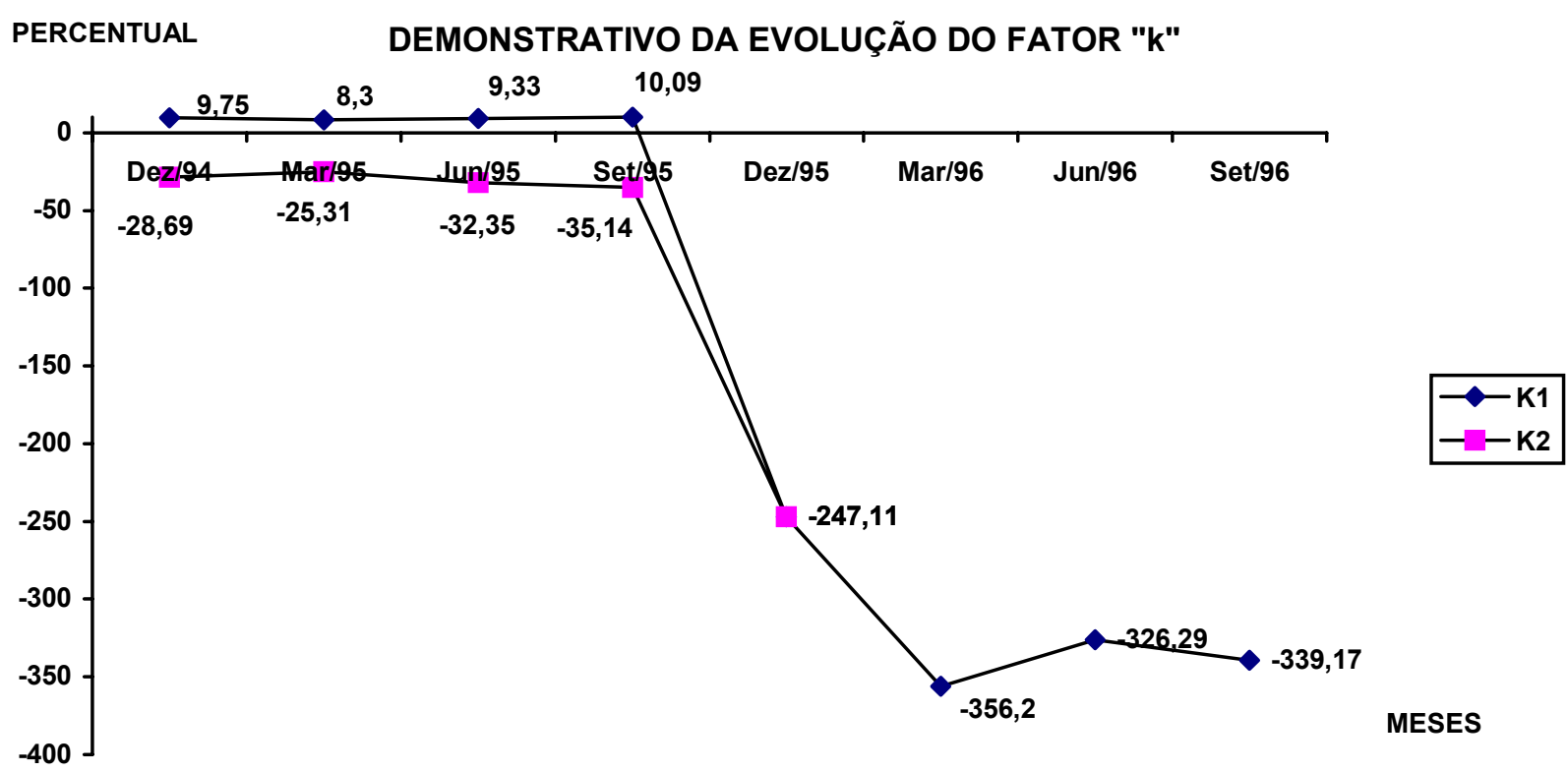

8. Real

PERCENTUAL DEMONSTRATIVO DA EVOLUÇÃO DO FATOR "k"

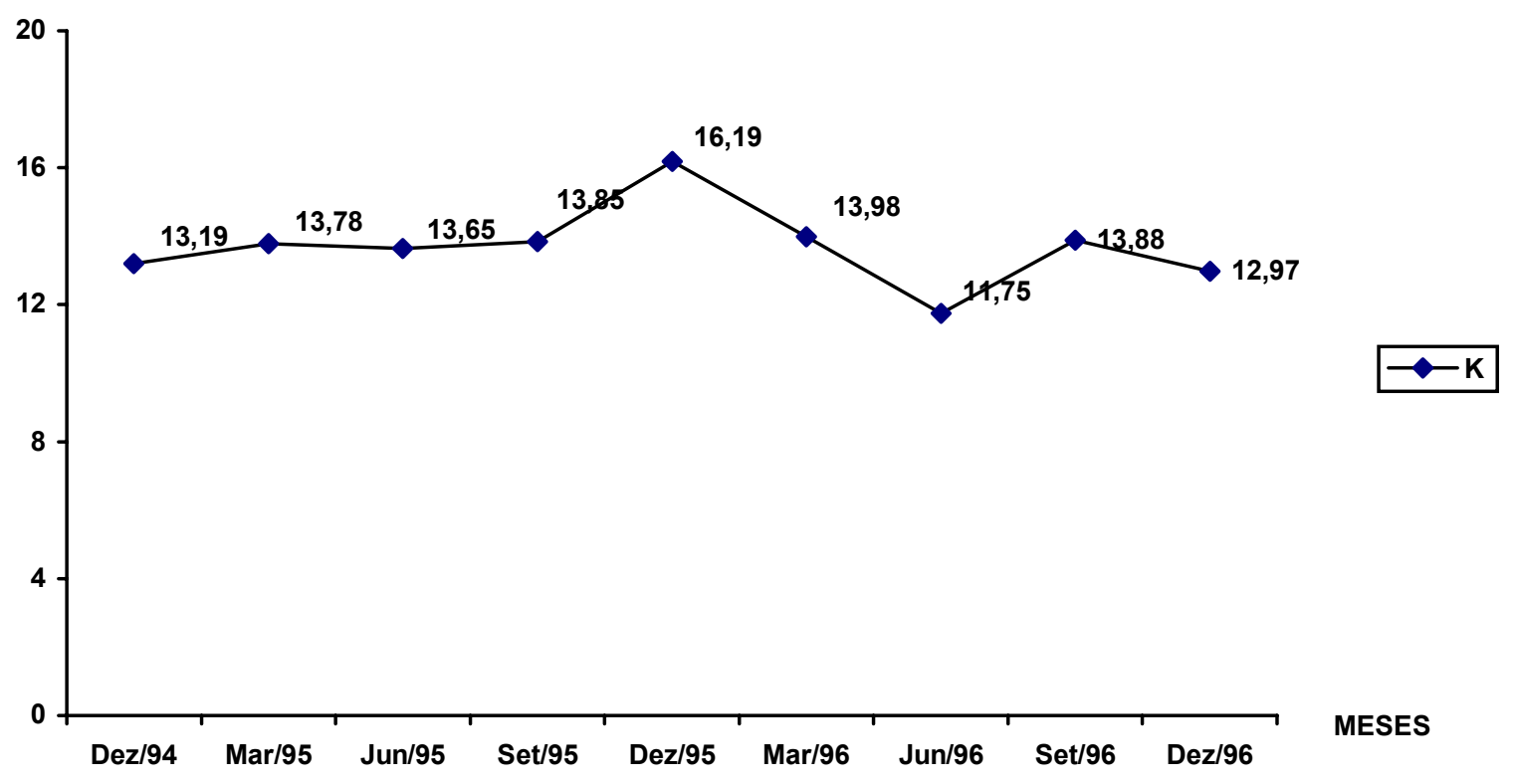

${ }^{20} \mathrm{~K} 1$ = Índice de capitalização até set/96 com base nos balancetes divulgados pelo Banco Nacional; K2 = índice de capitalização, simulado, considerando baixados ativo: 50\% dos Empréstimos e Financiamentos, inclusive imobiliários e rurais. 


\section{Safra}

PERCENTUAL ～～～DEMONSTRATIVO DA EVOLUÇÃO DO FATOR "k"

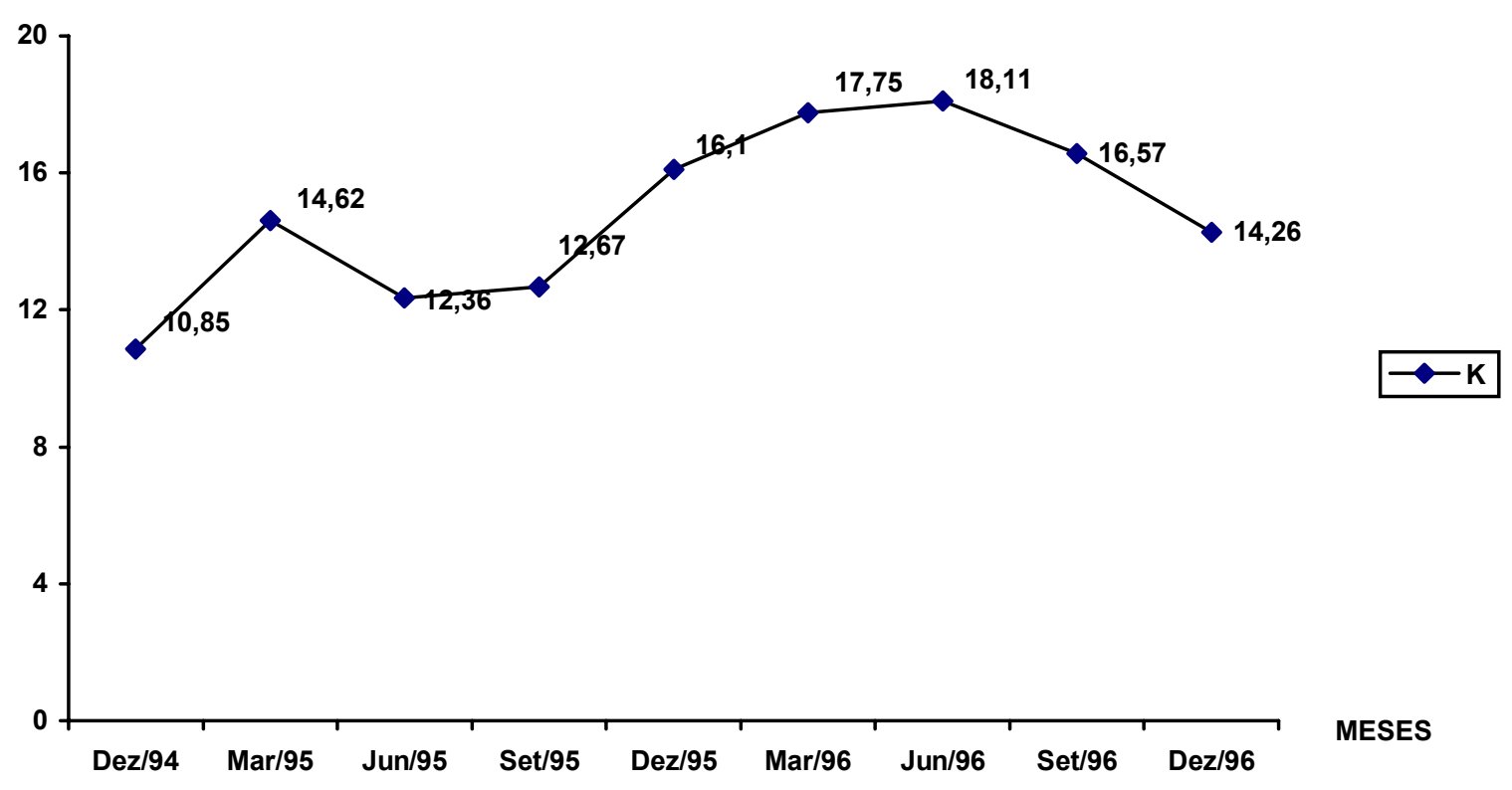

10. Meridional

PERCENTUAL DEMONSTRATIVO DA EVOLUÇÃO DO FATOR "k"

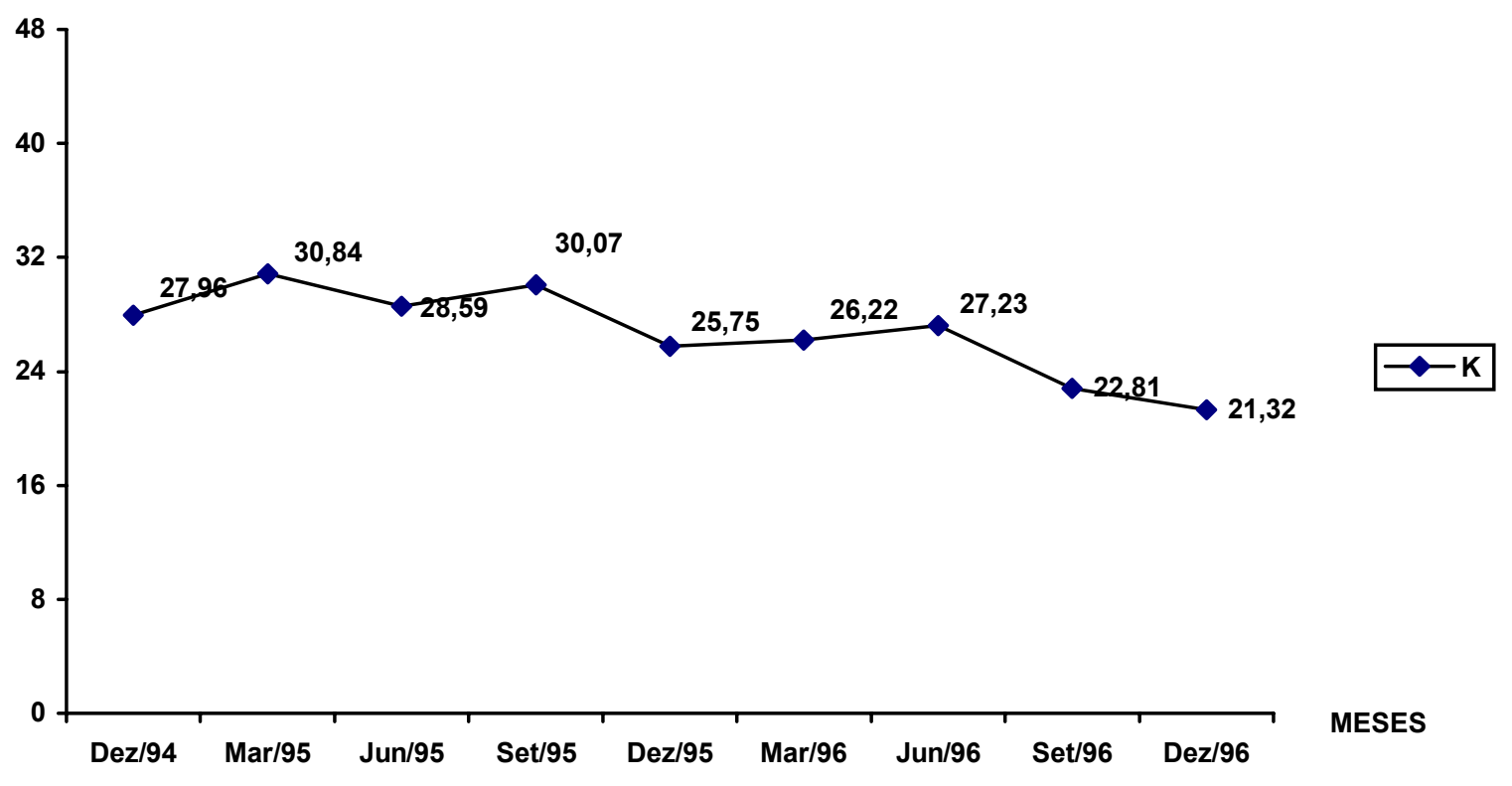


TABELA 1

\begin{tabular}{|c|c|c|c|c|c|c|c|c|c|}
\hline \multicolumn{10}{|c|}{ ÍNDICE DE CAPITALIZAÇÃO (\%) } \\
\hline BCOS\TRIM. & DEZ/94 & MAR/95 & JUN/95 & SET/95 & DEZ/95 & MAR/96 & JUN/96 & SET/96 & DEZ/96 \\
\hline BRASIL & 11,86 & 9,82 & 7,54 & 8,79 & 8,94 & 7,05 & 13,67 & 10,46 & 9,39 \\
\hline ECONÔMICO & 12,67 & 13,04 & 14,74 & $-57,30$ & $-64,39$ & $-93,79$ & $-130,03$ & $-238,44$ & $-218,42$ \\
\hline NORDESTE & 8,32 & 7,13 & 7,65 & 7,32 & 6,78 & 14,16 & 13,77 & 12,74 & 12,16 \\
\hline BAMERINDUS & 12,02 & 10,96 & 10,93 & 11,66 & 9,74 & 11,96 & 17,08 & 14,11 & 14,38 \\
\hline ITAÚ & 25,17 & 22,82 & 22,56 & 24,12 & 23,90 & 23,77 & 22,03 & 21,58 & 19,85 \\
\hline BRADESCO & 27,32 & 24,86 & 26,42 & 25,31 & 28,46 & 26,14 & 25,34 & 26,03 & 25,33 \\
\hline NACIONAL & 9,75 & 8,30 & 9,33 & 10,09 & $-247,11$ & $-356,20$ & $-326,29$ & $-339,17$ & $(*)$ \\
\hline REAL & 13,19 & 13,78 & 13,65 & 13,85 & 16,19 & 13,98 & 11,75 & 13,88 & 12,97 \\
\hline SAFRA & 10,85 & 14,62 & 12,36 & 12,67 & 16,10 & 17,75 & 18,11 & 16,57 & 14,26 \\
\hline MERIDIONAL & 27,96 & 30,84 & 28,59 & 30,07 & 25,75 & 26,22 & 27,23 & 22,81 & 21,32 \\
\hline
\end{tabular}

FONTE: Balancete/Balanço Patrimonial (SISBACEN)

(*) Documento da instituição não validado pelo BACEN. Pesquisa realizada em 18/01/98 às 14:43 min.

A Tabela 1 mostra a evolução trimestral do índice de capitalização (k=Patrimônio Líquido Ajustado (PLA)/Ativo Ponderado pelo Risco (Apr) dos dez bancos pesquisados, a ser comparado com o índice de 8\% ${ }^{21}$, até então vigente, exigido pela Resolução n 2099.

Com exceção do Bamerindus, que foi submetido a um processo de intervenção do Banco Central, e, mesmo assim, apresenta bons índices de capitalização no período, os demais bancos apresentaram indicadores que retratam adequadamente a capitalização dos bancos constantes da amostra.

Os bancos Econômico e Nacional, por apresentarem passivo a descoberto, e por estarem também sob intervenção, evidenciam índices de capitalização excessivamente

\footnotetext{
21 O Conselho Monetário Nacional, em 25/06/97, através da Resolução no 2.399 , alterou o índice para $10 \%$. O Banco Central do Brasil, em 27/11/97, novamente modificou referido índice, elevando-o para 11\%, conforme Circular 1784.
} 
negativos. Até a conclusão deste trabalho, apenas o Banco Nacional não tinha atualizado totalmente os seus demonstrativos, faltando o trimestre de dezembro de 1996.

Os bancos privados encontram-se bem mais capitalizados que os bancos públicos, com destaque para o Bradesco, que manteve no período média de $26 \%$.

Dos bancos públicos, o Meridional destaca-se por apresentar uma boa margem para alavancar suas operações. É importante ressaltar que a função institucional dos bancos públicos de fomentar o desenvolvimento de suas regiões, implica necessariamente em um elevado número de operações de crédito, principalmente de longo prazo, - consideradas pelo BACEN como operações com risco normal e portanto com peso $100 \%$-, e, conseqüentemente, a necessidade de um aporte de recursos compatível para cobrir os riscos a elas inerentes.

Os bancos privados, diferentemente, aplicam os seus recursos substancialmente em títulos públicos e privados, fundos de investimento e operações de crédito de curto prazo, com elevado giro e margem de lucro, o que possibilita manter um portifólio de ativos de baixo risco em seus balanços e elevados índices de capitalização. 


\section{BIBLIOGRAFIA}

ADEQUACY, Agreement on Capital - Bankers' set the Standard, Banking World, Agosto, 1988.

ADEQUACY, Capital - Playing by the same Rules, Banking World, Janeiro/1988.

ALEXANDER, Williard A. - Managing Off Balance Sheet Risk, The Bankers Magazine, Novembro-Dezembro/1988.

ANDIMA. Novas Regras redefinem o Sistema Financeiro-Edição Especial

BACEN, DENOR/COBAN - Projeto Basiléia, Transparências apresentadas no Seminário sobre o Acordo da Basiléia e as Instituições Financeiras de Desenvolvimento, Brasília, 1995.

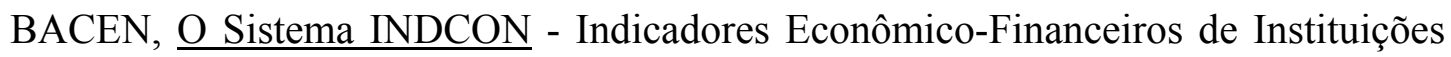
sob Acompanhamento e Controle do Banco Central do Brasil, Brasília, 1994.

BASOMBRIO, Ignacio. Notas sobre Las Normas Del Comite de Basileia y La Banca de Desarrollo, ALIDE, Outubro, 1994.

BENSTON, George J. - The Purpose of Capital for Institutions with Government Insured Deposits, in: Global Risk Based Capital Regulations - Capital Adequacy, Edited by Charles A. Stone and Anne Zissu, Irwin, Illinois, 1994.

BERGER, Allen N.; UDELL, Gregory F. - Did Risk-Based Capital Allocate Bank

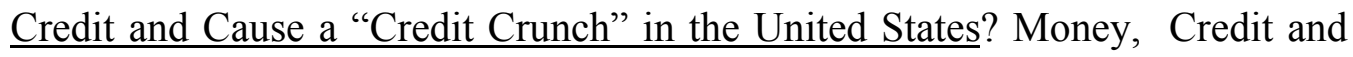
Banking. 
BYDALEK, Paul L. - Bancos, transparência e auto-regulamentação. Gazeta Mercantil, 31/01/97, p. A-3.

CAPELO, Emílio Recamond - $\underline{\text { Racionamento de Capital - Análise Determinística de }}$ Propostas de Investimento, Dissertação de Mestrado apresentada à Escola de Administração de Empresas de São Paulo (EAESP) da Fundação Getúlio Vargas, São Paulo, 1977.

CAMPELO, Murilo. O Acordo da Basiléia e a Indústria Bancária Brasileira. Revista Conjuntura Econômica, Outubro de 1995, p.34.

CARVALHO, Sílvio de Aparecido - Desenvolvimento de Novas Técnicas para a Gestão Bancária no Brasil, Tese apresentada à Faculdade de Economia, Administração e Contabilidade da Universidade de São Paulo, São Paulo, 1993.

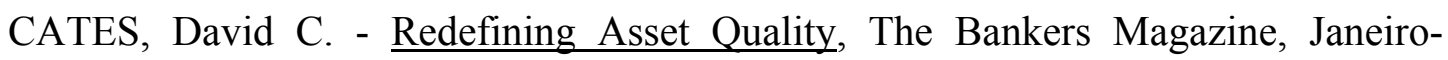
Fevereiro/1988.

CATES, David C.; MORGAN, Bruce W. - The Trouble with Risk-Based Capital, in: Global Risk Based Capital Regulations - Management and Finding Strategies, Edited by Charles A. Stone and Anne Zissu, Irwin, Illinois, 1994.

CHAMBERS, R. J. - Income and Capital: Fisher's Legacy, in: Journal of Accounting Reseach, primavera de 1971.

CHURCHMAN, C. West - Introdução à Teoria dos Sistemas, Editora Vozes, $2^{\text {a }}$ Edição, Petrópolis, 1972.

COMPTON, Eric N. - Princípios das Atividades Bancárias, Obra traduzida pelo Institulo Brasileiro de Ciência Bancária (IBCB), $3^{\text {a }}$ Edição, São Paulo, 1990. 
COSIF - Plano Contábil das Instituições do Sistema Financeiro, BACEN.

CVM - Reavaliação de Ativos, Deliberação nº 183, de 19 de junho de 1995.

DREYFUSS, Peat Marwick - Adequação de Capital Sensível ao Risco,_Atualidades na Área Financeira, KPMG, Junho, 1989.

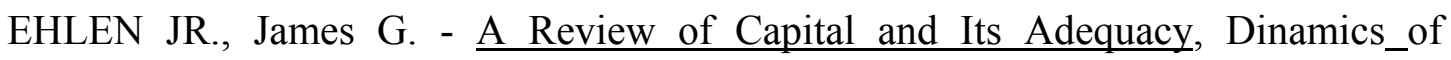
Banking.

ELLERT, James C. - Bank Financial Management, Obra traduzida pelo Institulo Brasileiro de Ciência Bancária (IBCB), São Paulo, 1990.

FERREIRA, Aurélio Buarque de Holanda - Novo Dicionário Aurélio da Lingua Portuguesa, Editora Nova Fronteira, 2a Edição, Rio de Janeiro, 1986.

FORTUNA, Eduardo - Mercado Financeiro - Produtos e Serviços, Editora Qualitymark, 2a edição, Rio de Janeiro, 1993.

GITMAN, Lawrence J. - Princípios de Administração Financeira, Editora Harbra, $3^{\mathrm{a}}$ Edição, São Paulo, 1984.

GONÇALVES, Everton P. de Souza - Value at Risk. Disclousure das Transações Financeiras-Julho 1997.p. 5.

HALL, Maximilian J. B. - The Measurement and Assessment of Capital Adequacy for Banks: A Crítique of the G-10 Agrement, in: Global Risk Based Capital Regulations - Capital Adequacy, Edited by Charles A. Stone and Anne Zissu, Irwin, Illinois, 1994. 
HENDRICKSEN, Eldon S. - Accounting Theory, Homewood: Richard D. Irwin, $4^{\text {a }}$ Edição, Illinois, 1982.

HUMPHREY, Stacie F.; HUMPHREY, David B. - $\underline{\text { How Risk-Based Capital Will }}$ Affect Bank Operations, The Bankers Magazine, Março-Abril, 1988.

IUDÍCIBUS, Sérgio de - Teoria da Contabilidade, Editora Atlas, $2^{\mathrm{a}}$ edição, São Paulo, 1987.

KAPSTEIN, Ethan B. - Supervising International Banks: Origins and Implications of The Basle Accord, in: Global Risk Based Capital Regulations - Capital Adequacy, Edited by Charles A. Stone and Anne Zissu, Irwin, Illinois, 1994.

KEETON, William R. - Risk Based Capital Requirements for Comercial Banks, in: Global Risk Based Capital Regulations - Capital Adequacy, Edited by Charles A. Stone and Anne Zissu, Irwin, Illinois, 1994.

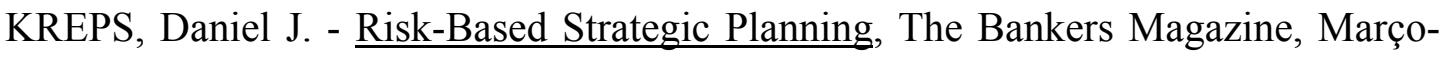
Abril/1994.

MAGLIANO, Augusto C. - Acordo sobre o Regime de Capitais Mínimos para Entidades Financeiras e suas Consequências, Trabalho apresentado no X Congresso da Federação Iberoamericana de Associações Financeiras (FIBAFIN), em Assunção, Paraguai, in: Revista da ANDIMA, 1994.

MAISEL, Sherman J. - Risk and Capital Adequacy in Commercial Banks, National Bureau of Economic Reseach, Chicago, 1981. 
MARTINS, Eliseu - Contribuição à Avaliação do Ativo Intangível, Tese apresentada à Faculdade de Economia, Administração e Contabilidade da Universidade de São Paulo, São Paulo, 1972.

MARTINS, Eliseu; ASSAF NETO, Alexandre - Administração Financeira- As Finanças das Empresas sob Condições Inflacionárias, Editora Atlas, $1^{\text {a }}$ Edição, São Paulo, 1985.

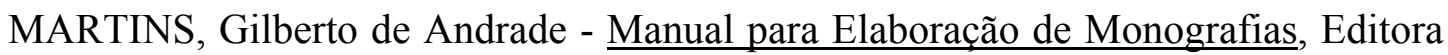
Atlas, $1^{a}$ Edição, São Paulo, 1992.

MONOBE, Massanori - Contribuição à Mensuração e Contabilização do Goodwill não Adquirido, Tese apresentada à Faculdade de Economia, Administração e Contabilidade da Universidade de São Paulo, São Paulo, 1987.

MOST, Kenneth S. - Accounting Theory, Grid Publishing, 2a Edição, 1982.

NAKAMURA, Angela Mie - Contribuição ao Estudo dos Procedimento e Evidenciação Contábeis Aplicáveis a Operações com Derivativos, voltados a Instituições Financeiras, Tese apresentada à Faculdade de Economia, Administração e Contabilidade da Universidade de São Paulo, São Paulo, 1996.

REED, Edward W.; GILL Edward K. - Bancos Comerciais e Múltiplos, Traduzido por Maria Claudia S. Ribeiro, Makson Books, São Paulo, 1994.

RESOLUÇÃO No 2099 DO CMN - Regulamentos: Anexo II e IV, de 17 de agosto de 1994. 
ROSENBERG, Barr; PERRY, Philip R. - The Fundamental Determinants of Risk in Banking, in: Risk and Capital Adequacy in Commercial Banks, National Bureau of Economic Reseach, Chicago, 1981.

SALOMON, Délcio Vieira - Como Fazer uma Monografia, Editora Martins Fontes,

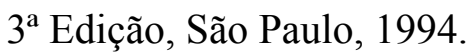

SOBRINHO, José Dutra Vieira - Matemática Financeira, Editora Atlas, $3^{\text {a }}$ Edição, São Paulo, 1986.

SHOME, Dilip K.; SMITH, Stephen D.; HEGGESTAD, Arnold A. - Do Banks Have Adequate Capital? The Bankers Magazine, Julho-Agosto/1987.

SWARY, Itzhak; TOPF, Barry - Global Financial Deregulation - Commercial Banking at the Crossroads, Blackwell Finance, $1^{\text {a }}$ Edição, Cambridge, Massachusetts, 1992.

TROSTER, Roberto Luis - O Capital Mínimo dos Bancos no Brasil, Seminário sobre o Acordo da Basiléia e as Instituições Financeiras de Desenvolvimento, ABDE, Brasília, maio/1995.

WALMSLEY, Julian - Understanding The International Capital Adequacy Proposals, The Bankers Magazine, Setembro-Outubro/1987. 
ANEXO 1

REGULAMENTAÇÃO BANCÁRIA INTERNACIONAL

\begin{tabular}{|c|c|c|c|c|c|}
\hline País & Solvência & Riscos & $\begin{array}{l}\text { Exigências } \\
\text { de reservas }\end{array}$ & $\begin{array}{l}\text { Restrições de } \\
\text { Investimento }\end{array}$ & Outros \\
\hline Suíça & $\begin{array}{l}\text { Regras de adequação de } \\
\text { capital conservadoras. } \\
\text { Incluem off-balance- } \\
\text { sheet. }\end{array}$ & $\begin{array}{l}\text { Empréstimos sem } \\
\text { garantias não podem } \\
\text { exceder a } 20 \% \text { do } \\
\text { capital. Empréstimos } \\
\text { com garantias não } \\
\text { podem exceder } 40 \% \text {. }\end{array}$ & $\begin{array}{l}\text { Reserva Primária - } 2,5 \% \\
\text { das obrigações de curto } \\
\text { prazo. Reserva } \\
\text { Secundária - } 33 \% \text { do } \\
\text { que exceder as } \\
\text { obrigações de curto } \\
\text { prazo. }\end{array}$ & Nenhuma & $\begin{array}{l}\text { Obrigatoriedade de } \\
\text { constituir reserva legal } \\
\text { de } 5 \% \text { do lucro líquido. }\end{array}$ \\
\hline Alemanha & $\begin{array}{l}\text { Empréstimos e } \\
\text { investimentos: máx. } 18 \\
\text { vezes o capital + lucros } \\
\text { retidos. Exigências de } \\
\text { capital do BIS. }\end{array}$ & $\begin{array}{l}\text { Máx. } 50 \% \text { do PL para } 1 \\
\text { cliente. Total dos } \\
\text { empréstimos }>15 \% \text { do } \\
\text { PL limitado a } 800 \% \\
\text { deste. }\end{array}$ & $\begin{array}{l}\text { Obrigação de manter } \\
\text { parcelas dos depósitos } \\
\text { em reserva, de acordo } \\
\text { com a maturidade. }\end{array}$ & Nenhuma & $\begin{array}{l}\text { Posição diária em } \\
\text { moeda estrangeira: máx. } \\
30 \% \text { do PL. }\end{array}$ \\
\hline França & $\begin{array}{l}\text { Limite min. de fundos } \\
\text { para os ativos fixos: } \\
60 \% \text { do PL + fontes de } \\
\text { longo prazo. Ativos } \\
\text { líquidos: mín. } 100 \% \text { das } \\
\text { obrigações de curto } \\
\text { prazo. Exigências de } \\
\text { capital do BIS. }\end{array}$ & $\begin{array}{l}\text { Máx. } 40 \% \text { do PL para } 1 \\
\text { cliente, no caso de } \\
\text { concessão de garantia. } \\
\text { O total das garantias } \\
\text { oferecidas não podem } \\
\text { exceder a } 800 \% \text { do } \\
\text { valor do PL. }\end{array}$ & $\begin{array}{l}\text { Variam, de } 1 \text { a } 5 \% \text { dos } \\
\text { itens de curto prazo. }\end{array}$ & $\begin{array}{l}\text { Participar no máx. com } \\
20 \% \text { do patrimônio de } \\
\text { companhia não } \\
\text { financeira. }\end{array}$ & $\begin{array}{l}\text { Somente bancos } \\
\text { autorizados são } \\
\text { intermediários de } \\
\text { negócios no exterior. }\end{array}$ \\
\hline Reino Unido & $\begin{array}{l}\text { A exigência de capital } \\
\text { mínimo para os ativos } \\
\text { ponderados pelo risco é } \\
\text { de } 8 \% \text {, sendo } 4 \% \text { de } \\
\text { capital principal. } \\
\text { Exigências de capital do } \\
\text { BIS. }\end{array}$ & $\begin{array}{l}\text { Máx. } 25 \% \text { do PL para } 1 \\
\text { cliente sem prévia } \\
\text { notificação. } 10 \% \text { para } \\
\text { os clientes notificados. }\end{array}$ & & Nenhuma & $\begin{array}{l}\text { FSA de } 1986 \text { introduziu } \\
\text { as organizações auto- } \\
\text { reguláveis. }\end{array}$ \\
\hline Japão & $\begin{array}{l}\text { Capital/ativo: } 4 \% \text { para } \\
\text { bancos sem operações } \\
\text { internacionais; } 6 \% \text { para } \\
\text { bancos com agência no } \\
\text { exterior.Em } 1988 \\
\text { implementou as } \\
\text { exigências do BIS. }\end{array}$ & $\begin{array}{l}\text { Máx. } 20 \% \text { do capital do } \\
\text { banco para um único } \\
\text { cliente. }\end{array}$ & $\begin{array}{l}\text { Menor do que } 800 \\
\text { bilhões de yens }=0,125 \text {; } \\
\text { de } 800 \text { bilhões até } 2.500 \\
\text { bilhões }=0,625 ; \text { mais do } \\
\text { que } 2.500 \\
\text { bilhões }=1,625 \text {. }\end{array}$ & $\begin{array}{l}\text { Somente para atividades } \\
\text { de captação de recursos } \\
\text { via depósitos e de } \\
\text { aplicação via } \\
\text { empréstimos. }\end{array}$ & $\begin{array}{l}\text { limite diário para } \\
\text { posição em moeda } \\
\text { estrangeira }\end{array}$ \\
\hline Canadá & $\begin{array}{l}\text { Capital primário e } \\
\text { secundário de acordo } \\
\text { com o risco bancário. } \\
\text { Em } 1988 \text { implementou } \\
\text { as exigências do BIS }\end{array}$ & $\begin{array}{l}\text { Máx. } 25 \% \text { do PL p/um } \\
\text { único cliente ou grupo. } \\
\text { Para subsidiárias de } \\
\text { bancos estrangeiros } \\
\text { máx. } 50 \% \text {; no agregado, } \\
\text { as exposições ao risco } \\
\text { limitam-se a } 400 \% \text { do } \\
\text { PL. }\end{array}$ & $\begin{array}{l}10 \% \text { dos depósitos à } \\
\text { vista, } 2 \text { e } 3 \% \text { dos outros } \\
\text { depósitos, conforme o } \\
\text { caso. }\end{array}$ & $\begin{array}{l}\text { Bancos são proibidos de } \\
\text { fazer investimentos } \\
\text { maiores do que } 10 \% \text { do } \\
\text { PL, bem como exercer } \\
\text { atividades não- } \\
\text { bancárias }\end{array}$ & \\
\hline $\begin{array}{l}\text { Estados } \\
\text { Unidos }\end{array}$ & $\begin{array}{l}\text { Varia de } 5,5 \% \text { a } 6 \% \\
\text { para o capital primário e } \\
\text { total de acordo com o } \\
\text { tamanho do banco. Em } \\
1989 \text { implementou as } \\
\text { exigências do BIS. }\end{array}$ & $\begin{array}{l}\text { Proibição para fazer } \\
\text { empréstimos sem } \\
\text { garantias a um único } \\
\text { cliente que exceda a } \\
15 \% \text { do PL. }\end{array}$ & $\begin{array}{l}3 \% \text { sobre o saldo de } \\
\text { determinadas } \\
\text { transações, limitado a } \\
\text { US\$ } 41,1 \text { milhões; } \\
\text { acima deste valor, } 12 \% \text {. }\end{array}$ & $\begin{array}{l}\text { A Lei Glass-Stegall Act } \\
\text { and the Bank Holding } \\
\text { Company Act, } \\
\text { distinguiu os bancos } \\
\text { comerciais dos de } \\
\text { investimento. }\end{array}$ & \\
\hline
\end{tabular}


ANEXO 2

PLANILHA ALFA BALANCETE DE VERIFICAÇÃO/BALANÇO

\begin{tabular}{|c|c|c|c|c|c|c|}
\hline \multicolumn{7}{|c|}{ BALANCETE DE VERIFICAÇAO/BALANÇO } \\
\hline & & & BANCO "A" & Dez/94 & & \multirow[b]{2}{*}{ PASSIVO } \\
\hline & \multicolumn{2}{|l|}{ ATIVO } & & & & \\
\hline & & & Apr & & & \\
\hline \multicolumn{2}{|c|}{ RISCO NULO (P. 0\%) } & & & & & \\
\hline $1111,00,00-9$ & 287.765 & & 0 & & $410,00,00-7$ & 24.726 .324 \\
\hline $113,00,00-5$ & 0 & & 0 & & $420,00,00-6$ & 6.680 .153 \\
\hline $121,00,00-8$ & 5.582 .120 & & 0 & & $430,00,00-5$ & 0 \\
\hline $123,00,00-4$ & 0 & & 0 & & $440,00,00-4$ & 14.156 \\
\hline $131,00,00-7$ & 326.472 & & 0 & & $450,00,00-3$ & 662.697 \\
\hline $132,00,00-0$ & 1.607 .407 & & 0 & & $460,00,00-2$ & 19.450 .767 \\
\hline $134,00,00-6$ & 2.772 .810 & & 0 & & $490,00,00-9$ & 7.282 .419 \\
\hline \multirow{2}{*}{$142,00,00-9$} & 3.260 .971 & & 0 & & $510,00,00-4$ & 7.648 \\
\hline & 13.837 .545 & $20,79 \%$ & 0 & & & 58.824 .164 \\
\hline \multicolumn{2}{|c|}{ RISCO RED. (P. 20\%) } & & & & $611,00,00-4$ & 675.241 \\
\hline $112,00,00-2$ & 0 & & 0 & & $612,00,00-7$ & 6.115 .130 \\
\hline $114,00,00-8$ & 55.469 & & 11.094 & & $613,00,00-0$ & 326.680 \\
\hline $115,00,00-1$ & 3.678 .391 & & 735.678 & & $614,00,00-3$ & 7.927 \\
\hline \multirow[t]{3}{*}{$141,00,00-6$} & 47.334 & & 9.467 & & $615,00,00-6$ & 352.675 \\
\hline & 3.781 .194 & $5,68 \%$ & 756.239 & & $617,00,00-2$ & 0 \\
\hline & & & & & $618,00,00-5$ & $(1.724 .887)$ \\
\hline \multicolumn{2}{|c|}{ RISCO RED. (P. 50\%) } & & & & $619,00,00-8$ & 0 \\
\hline $122,00,00-1$ & 2.279 .309 & & 1.139 .655 & & PLA $=$ & 5.752 .766 \\
\hline $125,00,00-0$ & 0 & & 0 & & & \\
\hline $126,00,00-3$ & 761 & & 381 & & $\sum$ Apr $=$ & 48.502 .855 \\
\hline $143,00,00-2$ & 91.317 & & 45.659 & & PLE $=$ & 3.880 .228 \\
\hline \multirow{2}{*}{$164,00,00-3$} & 0 & & 0 & & & \\
\hline & \begin{tabular}{|r|}
2.371 .387 \\
\end{tabular} & $3,56 \%$ & 1.185 .694 & & K & $11,86 \%$ \\
\hline \multicolumn{7}{|c|}{ RISCO NORMAL(P.100\%) } \\
\hline $133,00,00-3$ & 45.711 & & 45.711 & & & \\
\hline $135,00,00-9$ & 0 & & 0 & & & \\
\hline $144,00,00-5$ & 13.542 & & 13.542 & & & \\
\hline $161,00,00-4$ & 7.588 .293 & & 7.588 .293 & & & \\
\hline $162,00,00-7$ & 9.738 .747 & & 9.738 .747 & & & \\
\hline $163,00,00-0$ & 11.556 .903 & & 11.556 .903 & & & \\
\hline $165,00,00-6$ & 0 & & 0 & & & \\
\hline $166,00,00-9$ & 0 & & 0 & & & \\
\hline $167,00,00-2$ & 5.925 & & 5.925 & & & \\
\hline $169,00,00-8$ & $(159.666)$ & & -159.666 & & & \\
\hline $171,00,00-3$ & 0 & & 0 & & & \\
\hline $173,00,00-9$ & 0 & & 0 & & & \\
\hline $175,00,00-5$ & 0 & & 0 & & & \\
\hline $177,00,00-$ & 0 & & 0 & & & \\
\hline $179,00,00-7$ & 0 & & 0 & & & \\
\hline $181,00,00-2$ & 20.211 & & 20.211 & & & \\
\hline $182,00,00-5$ & 3.251 .126 & & 3.251 .126 & & & \\
\hline $183,00,00-8$ & 173.753 & & 173.753 & & & \\
\hline $184,00,00-1$ & 259 & & 259 & & & \\
\hline $185,00,00-4$ & 44.806 & & 44.806 & & & \\
\hline $186,00,00-7$ & 817.072 & & 817.072 & & & \\
\hline $187,00,00-0$ & $\begin{array}{r}0 \\
\end{array}$ & & 0 & & & \\
\hline $188,00,00-3$ & 3.542 .318 & & 3.542 .318 & & & \\
\hline $189,00,00-6$ & $\begin{array}{r}0 \\
\end{array}$ & & 0 & & & \\
\hline $191,00,00-1$ & 0 & & 0 & & & \\
\hline $198,00,00-2$ & 88.064 & & 88.064 & & & \\
\hline $199,00,00-5$ & 335 & & 335 & & & \\
\hline $200,00,00-4$ & 7.661 .695 & & 7.661 .695 & & & \\
\hline \multirow[t]{2}{*}{$301,00,00-4$} & 2.171 .829 & & 2.171 .829 & & & \\
\hline & 46.560 .923 & $69,96 \%$ & 46.560 .923 & & & \\
\hline
\end{tabular}

